\title{
YARGITAY KARARLARI IŞIĞINDA YASAL ÖNALIM HAKKININ TAPUDA DÜŞÜK GÖSTERILEN BEDEL ÜZERINDEN KULLANILMASI
}

\author{
(Araştırma Makalesi)
}

DOI: https://doi.org/10.33717/deuhfd.998162

Dr. Öğr. Üyesi Özge ERBEK ODABAŞI*

\begin{abstract}
$\ddot{\mathbf{O z}}$
Tapu masraflarını azaltmak için tarafların satım sözleşmesinde bedeli düşük göstermesi bedel muvazaası dediğimiz hallerden biridir. İki taraf da edimini ifa ettiği zaman bir çekişme olarak mahkeme önüne gelmesi de söz konusu olmaz. Ancak satım konusu taşınmaz payl mülkiyete tabi ise, yasal önalım hakkı ortaya çıkacaktır. Yargıtay, bu durumda, kural olarak önalım hakkı sahibinin tapudaki düşük bedel üzerinden hakkını kullanabileceğini kabul etmektedir. Bununla birlikte, yeni kararlarında davalı alıcının, dava açılmadan önce harcı tamamlatması halinde, bu bedel üzerinden hakkın kullanılacağını kabul ettiği de vakidir.
\end{abstract}

\section{Anahtar Kelimeler}

Yasal önalım hakkl, Muvazaa, Bedelde muvazaa, Dürüstlük kuralı, Hakkın kötüye kullanımı

\section{EXERCISE OF LEGAL PREEMPTION RIGHT ON THE PRICE SHOWN LOWER IN REGISTRATION OF REAL ESTATE IN THE VIEW OF THE SUPREME COURT DECISIONS}

\section{(Research Article)}

\begin{abstract}
In order to reduce costs of the registration of real estate, the parties lower price in the sales contract is one of the cases we call simulation of price of real

Dokuz Eylül Üniversitesi Hukuk Fakültesi, Medeni Hukuk Anabilim Dalı Öğretim Üyesi, İzmir (ozge.erbek@deu.edu.tr), ORCID: 0000-0002-3707-0702 (Geliş Tarihi: 23.06.2021-Kabul Tarihi: 18.08.2021)
\end{abstract}

Dokuz Eylül Üniversitesi Hukuk Fakültesi Dergisi, Cilt: 23, Sayı: 2, 2021, s. 1001-1056 
property. When both parties fullfill their duties, it is out of question for them to appear in the court as a conflict. However, if the sale of the real property is subject to joint ownership, the legal preemption right will arise. The Supreme Court, in this situation, as a rule, accepts the exercise of the right of preemption on low price. However, according to the recent decisions of the Supreme Court, it is accepted that if the defendant buyer completes the fees of the title before the lawsuit is filed, he may exercise the sale price.

\section{Keywords}

Legal right of preemption, Simulation, Simulation of price of real property. The principle of good faith, The abuse of rights 


\section{GİRIŞ}

Yargıtay'ın yasal önalım hakkının kullanılmasının koşulları hususunda pek çok içtihadı mevcuttur. Tapuda satış bedelinin düşük gösterilmesi halinde, bu bedeli önalım bedeli olarak kabul eden içtihadı da bunlardan biridir. Burada bedel muvazaasının bir türü mevcuttur. Tarafların tapuda satış bedelini gerçek bedelden düşük göstermelerinin sebebi tapu masraflarını azaltmaktır. Bu halde, önalım hakkı sahibinin hakkını kullanmasını zorlaştırmak, ona zarar vermek amacı güdülmese de, Yargıtay bu bedeli önalım bedeli olarak kabul etmektedir.

Çalışmamızın ilk bölümünde yasal önalım hakkını ve hakkı kullanma koşullarını ana hatlarıyla değerlendireceğiz. Kullanılma koşulları bağlamında iki hususa ayrıca yer vereceğiz. Şöyle ki, Yargıtay, taşınmazın fiilen taksim edilip paydaşlar tarafindan bu taksime uygun olarak kullanılması ve paydaşlardan birinin kendi payını devretmesi halinde diğer paydaşlara önalım hakkı tanımamaktadır. Bundan başka, şeklen satış sözleşmesi bulunsa bile, gerçekte miras hukukuna ilişkin amaçlarla eşe, çocuklara, akrabaya yapılan devirlerde de önalım hakkının kullanılamayacağını kabul etmektedir. $\mathrm{Bu}$ iki halde önalım hakkının kullanılamaması açık kanun hükmünden ileri gelmemekte, Yargitay tarafından içtihat yoluyla ortaya konulmuş bulunmaktadır.

İkinci bölümde üç ihtimal dâhilinde Yargıtay uygulamasına göre önalım bedelini inceleyeceğiz. Birinci halde, satış bedelinin objektif değer artışlarına göre mahkeme tarafından belirlenmesi söz konusudur. Bu halde bedel muvazaası yoktur. Diğer iki ihtimalde ise, bedelin gerçekten yüksek veya düşük gösterilmesi söz konusudur. Yüksek gösterilmesi halinde Yargıtay gerçek bedelin ispatına imkân verip bu bedel üzerinden önalım hakk1nın kullanılabileceğini kabul etmektedir. Buna karşılık, bedelin düşük gösterilmesi halinde, kural olarak bu düşük bedeli önalım bedeli olarak kabul etmektedir.

\section{YASAL ÖNALIM HAKKININ TANIMI, HUKUKİ NITELİ̆ĞI,} KULLANILMASININ KOŞULLARI

\section{A. Tanımı ve Hukuki Niteliği}

Devir hakkının kisitlamaları; Yasal önalım hakki; Önalım hakkı sahibi kenar başlıklı TMK m. 732'ye göre, "Paylı mülkiyette bir paydaşın taşınmaz üzerindeki payını tamamen veya kısmen üçüncü kişiye satması hâlinde, diğer paydaşlar önalım hakkını kullanabilirler”. 
Yasal önalım hakkı (kanunî şuf’a) öğretide çeşitli biçimlerde tanımlanmıştır ${ }^{1}$. Yasal önalım hakkının bütün unsurlarını içeren bir tanım vermek gerekirse, "paylı taşınmaz mülkiyetinde bir paydaşın payını tamamen ve kısmen pay sahibi olmayan üçüncü bir kişiye satması halinde, diğer paydaşlara

Bu hususta bkz. Sebük, Tahir M.: Türk Medeni Kanununda Şüf’a, Vefa ve İştira Hakları, Kader Basımevi, İstanbul, 1951, s. 140-141; Feyzioğlu, Feyzi Necmettin: Şuf’a Hakkı, Fakülteler Matbaası, İstanbul, 1959, s. 5; Taman Şıpka, Şükran: Türk Hukukunda Kanunî Önalım (Şuf’a) Hakkı (MK.m.659) Hukuki Niteliği ve Kullanma Koşulları, Alfa Basım Yayım, İstanbul, 1994, s. 2 vd.; Ayan, Mehmet: "Kanuni Şuf'a Hakkı" (Şuf’a), Prof. Dr. Halil CiN'e Selçuk Üniversitesinde 10. Hizmet Yılı Armağanı, Özel Sayı, Konya, 1995, s. 336; Kırca, Çiğdem: “Önalım Hakkı Konusunda Medeni Kanundaki Değişiklikler”, Prof. Dr. Ömer TEOMAN'a 55. Yaş Günü Armağanı, İstanbul, 2002, s. 1179; Erkan, Vehbi Umut: Türk Medeni Kanunu'nda Yasal Önalım Hakkı (MK. md. 732, 733, 734), Ankara, 2006 (Yayımlanmamış yüksek lisans tezi), s. 5 vd.; Eren, Fikret: "Türk Medeni Kanununa Göre Yasal Önalım Hakkı", Gazi Üniversitesi Hukuk Fakültesi Dergisi, C. XII, Y. 2008, S. 1-2, s. 106; Eren, Fikret: Mülkiyet Hukuku (Mülkiyet), Yetkin Yayınevi, Ankara, 2011, s. 395; Tunaboylu, Müslim: Önalım (Şuf’a) Davaları, 5. Baskı, Yetkin Yayınevi, Ankara, 2013, s. 28; Aydoğdu, Murat: Yasadan ve Sözleşmeden Doğan Önalım Hakkı, 1. Baskı, Adalet Yayınevi, Ankara, 2013, s. 10; Özenli, Soysal: Uygulamada Önalım (Şuf'a) Davaları, 2. Basım, Kazancı Yayınları, Ankara, 1990, s. 10 vd.; Yıldız, Ekrem: Önalım Davaları, 2. Baskı, Vedat Kitapçıllk, İstanbul, 2008, s. 3 vd.; Akalp-Demirtabak, Didem: Yasal Önalım Hakkı, 1. Bask1, On İki Levha Yayınları, İstanbul, 2010, s. 5 vd.; Günay, Erhan: Önalım Hakk1, 2. Bask1, Seçkin Yayınevi, Ankara, 2018, s. 15 vd.; Kırkbeşoğlu, Nagehan: Önalım Hakk1, 1. Bask1, On İki Levha Yayınları, İstanbul, 2020, s. 3 vd.; Suata, İlay Zeynep: Kanuni Önalım Hakkı, 1. Baskı, Yetkin Yayınevi, Ankara, 2020, s. 15 vd.; Ruhi, Canan/ Ruhi, Ahmet Cemal: Önalım Hakkına Dayalı Tapu İptali ve Tescil Davaları, Yenilenmiş 4. Bask1, Seçkin Yayınevi, Ankara, 2020, s. 35; Saymen, Ferit Hakk1/Elbir, Halit Kemal: Türk Eşya Hukuku, Filiz Kitabevi, İstanbul, 1963, s. 371; Gürsoy, Kemal Tahir/Eren, Fikret/Cansel, Erol: Türk Eşya Hukuku, 2. Bask1, Ankara Üniversitesi Hukuk Fakültesi Yayınları, Ankara, 1978, s. 614; Tekinay, Selahattin Sulhi: Taşınmaz Mülkiyetinin Takyitleri II/1, Filiz Kitabevi, İstanbul, 1988, s. 38; Akipek, Jale/Akıntürk, Turgut/Ateş, Derya: Eşya Hukuku, 2. Baskı, Beta Yayınevi, İstanbul, 2018, s. 553; Oğuzman, M. Kemal/Seliçi, Özer/Oktay-Özdemir, Saibe: Eşya Hukuku, 22. Bası, Filiz Kitabevi, İstanbul, 2020, s. 632; Sirmen, Lale: Eşya Hukuku, 8. Baskı, Yetkin Yayınevi, Ankara, 2020, s. 458; Aybay, Aydın/Hatemi, Hüseyin: Eşya Hukuku, Vedat Kitapçılık, İstanbul, 2012, s. 194; Esener, Turhan/Güven, Kudret: Eşya Hukuku, 8. Bası, Yetkin Yayınevi, Ankara, 2019, s. 312; Ayan, Mehmet: Eşya Hukuku II, Mülkiyet, 9. Bası, Seçkin Yayınevi, Ankara, 2016, s. 384; Ertaş, Şeref: Eşya Hukuku, İzmir, 11. Bask1, Fakülteler Yayınevi, 2014, s. 391; Meier-Hayoz, Arthur: Berner Kommentar, Kommentar zum Schweizerischen Privatrecht, Das Sachenrecht, Das Eigentum, Grundeigentum II, Art. 680-701, Bern, 1975, Art. 682, N. 34; Rey, Heinz: Die Grundlagen des Sachenrechts und das Eigentum, Band I, Bern, 2000, N. 1235; Rey, Heinz/Strebel, Lorenz: Honsell, Heinrich/Vogt, Nedim Peter/Gesser, Thomas: Basler Kommentar (Bas.Kom.) Zivilgesetzbuch II, Art. 457-977 ZBG, Art 1-61 SchlT ZGB, Basel, 2011, Art. 681, N. 1. 
satılan payın dava açmak suretiyle öncelikli alıcısı olma hakkını veren, eşyaya bağl1, kurucu yenilik doğuran bir hak ${ }^{2 \text { "ctır. }}$

Yargıtay bir içtihadı birleştirme kararında önalım hakkını ayni hak olarak nitelendirmiştir ${ }^{3}$. Ancak daha sonra bu görüşünü değiştirip önalımın bir yenilik doğuran hak olduğunu kabul etmiştir ${ }^{4}$. Öğretideki baskın görüş de, önalım hakkının yenilik doğuran bir hak olduğu yönündedir ${ }^{5}$.

743 say1lı Türk Medeni Kanunu (MK m. 659) ve İsviçre Medeni Kanunu'nun (ZGB Art. 682) aksine 4721 say1lı Medeni Kanun bu hakkın kullanımı için dava açma zorunluluğu getirmiştir ${ }^{6}$.

\section{B. Kullanılmasının Koşulları}

\section{Paydaş Sıfatına Sahip Olmak}

Yasal önalım hakkı ancak paylı mülkiyete tabi taşınmazlar için söz konusudur. Dolayısıyla ancak paylı mülkiyete tabi bir taşınmazda pay sahibi olanlar önalım hakkına sahip olurlar. Yasal önalım hakkı, mülkiyetin özel

\footnotetext{
Akalp-Demirtabak, s. 8.

Bkz. YİBK, 20.06.1951 T., 13 E., 5 K. (07.11.1951 T. ve 7950 S. RG).

Bkz. YİBK, 11.02.1959 T., 10 E., 12 K. (29.04.1959 T., ve 10194 S. RG). Anayasa Mahkemesi, 12.12.2007 T., 2003/34 E. ve 2007/94 K. sayılı kararında önalımın ayni hak olduğu yönünde karar vermiştir. Bu kararın eleştirisi için bkz. Erkan, Vehbi Umut: “Anayasa Mahkemesi’nin 12.12.2007 Tarihli E. 2003/34 ve K. 2007/94 Sayılı Kararı Üzerine: Türk Medeni Kanunu'nda Yasal Önalım Hakkının Hukuki Niteliği ve Kullanılması", İnönü Üniversitesi Hukuk Fakültesi Dergisi C. 5, S. 1, Y. 2014, s. 284 vd.

5 Bu husustaki görüşler için bkz. Feyzioğlu, s. 106 vd.; Taman Şıpka, s. 20 vd.; Erkan, s. 19 vd.; Akalp-Demirtabak, s. 16 vd.; Kırkbeşoğlu, s. 17 vd.

6 Önalım hakkının dava yoluyla kullanılması zorunluluğu öğretinin çoğunluğu tarafından eleştirilmektedir. Bkz. Arpacı, Abdülkadir: "Eşya Hukukumuzda Yeni Medeni Kanunla Yapılan Değişikliklerden Bazılarına Kısa Bir Bakış”, Prof. Dr. Necip KOCAYUSUFPAŞAOĞLU'na Armağan, Ankara, 2004, s. 105; Aybay/Hatemi, s. $195-$ 196; Kırca, s. 1200-1202; Eren, s. 108; Gümüş, M. Alper: "6098 Sayılı Türk Borçlar Kanunu'nun Akdi Önalım Hakkına İlişkin Hükümlerinin (TBK m. 237/III. 238, 239 ve 240-242) Değerlendirilmesi”, Yeditepe Üniversitesi Hukuk Fakültesi Dergisi, Prof. Dr. Erhan ADAL'a Armağan, Özel Say1, C. VIII/2-IX/1, Y. 2011-2012, S. 1-2, s. 450; Buz, Vedat: Medeni Hukukta Yenilik Doğuran Haklar, Yetkin Yayınevi, Ankara, 2005, s. 158 vd. Karş. Burcuoğlu, Haluk: “4721 Sayılı Türk Medeni Kanunu'nun Önalım Hakkı Düzenlemesi ve Borçlar Kanunu'nun ve Türk Borçlar Kanunu Tasarısı'nın Sözleşmesel Önalım Hakkına İlişkin Düzenlemeleri Hakkında Bazı Gözlemler”, Medeni Hukuk Hocalarına Saygı Günleri, Medeni Hukukta Güncel Sorunlar ve Önemli Gelişmeler Sempozyumu, 26-27 Haziran 2008, İstanbul, 2011, s. 298. Ayrıca bkz. ve karş. Ertaş, s. 388, N. 1777 , s. 398 , N. 1830.
} 
hukuktan doğan yasal kısıtlamalarından ${ }^{7}$ biridir. Paylı mülkiyetin kurulmasıyla birlikte, bu kısıtlama da doğmuş olur ${ }^{8}$. Kanundan doğan bir kısıtlama olduğu için eşyaya bağlı borç ${ }^{9}$ etkisiyle tapu siciline şerhi gerekmeden her yeni malike karşı ileri sürülebilir ${ }^{10}$. Sözleşmesel önalım hakkının aksine şerhi gerekmediği gibi, caiz de değildir ${ }^{11}$. Yasal önalım hakkı kanundan doğduğu için herkes tarafından bilindiği varsayılır ${ }^{12}$.

Yasal önalım hakkının tanınmasının sebebi paylı mülkiyet ilişkisinde paydaşlar arasına yabancı üçüncü kişilerin girmesini engellemek, payların mümkün olduğunca bir veya birkaç paydaşın elinde toplanmasını sağlamak, giderek paylı mülkiyet ilişkisine son vermektir ${ }^{13}$.

Yasal önalım hakkı paya bağlı bir haktır, pay üzerinde kim hak sahibi ise onun tarafından kullanılabilir. Paya bağlı olduğu için önalım hakkının paydan ayrı devri veya miras yoluyla geçmesi de söz konusu değildir ${ }^{14}$.

\section{2. Önalım Olayının Gerçekleşmesi}

Sözleşmesel önalım hakkını düzenleyen TBK m. 240/1'e göre, “Önalım hakk1, taşınmazın satışı ya da ekonomik bakımdan satışa eşdeğer her türlü

$7 \quad \mathrm{Bu}$ kısıtlamanın mülkiyetin doğrudan kısıtlaması mı, yoksa dolaylı kısıtlaması $\mathrm{m} 1$ olduğu hususu da tartışmalıdır. Dolaylı kısıtlama olduğu yönünde bkz. Eren, Mülkiyet, s. 396; Oğuzman/Seliçi/Oktay-Özdemir, s. 634; Akalp- Demirtabak, s. 22-23. Doğrudan kısitlama olduğu yönünde bkz. Meier-Hayoz, Art. 682, N. 34-36; Rey, N. 1215;

Tuor, Peter/Schnyder, Bernhard/Schmid, Jörg/Rumo-Jungo, Alexandra: Das Schweizerische Zivilgesetzbuch,, 2009, s. 971, N. 26; Sirmen, s. 458; Erkan, s. 29. Karş. Gürsoy/Eren/Cansel, s. 596.

8 Feyzioğlu, s. 96; Tekinay, s. 39; Gürsoy/Eren/Cansel, s. 615; Eren, s. 108; Ayan, s. 389; Erkan, s. 35. Karş. Taman Şıpka, s. 37-38. Yargıtay da, önalım hakkının paylı mülkiyet ilişkisinin kurulduğu anda vücut bulduğu, payın satılmasıyla da kullanılabilir hale geldiği görüşündedir. Bkz. 14. HD, 2014/4065 E., 2014/7543 K., 09.06.2014 T.; 14. HD 2014/5481 E., 2014/9286 K., 10.07.2014 T.; 14. HD, 2016/278 E., 2018/64 K., 08.01.2018 T. (http://www.kazanci.com.tr/. Erişim tarihi: 01.10.2020)

9 Bu hususta bkz. Erel, Şafak: Eşyaya Bağlı Borç, Ankara Üniversitesi Siyasal Bilgiler Fakültesi Yayınları, Ankara, 1982, s. 33.

10 Saymen/Elbir, s. 376; Taman Şıpka, s. 32; Eren, s. 108-109; Akalp-Demirtabak, s. 45.

11 Eren, s. 108; Oğuzman/Seliçi/Oktay-Özdemir, s. 636; Kırca, s. 1180; BGE 117 II 544.

12 Eren, s. 108.

13 Feyzioğlu, s. 105-106; Tekinay, s. 39; Saymen/Elbir, s. 376; Ayan, Şuf'a, s. 336; Ayan, s. 385; Erkan, s. 7; Eren, 109; Akipek/Akıntürk, Ateş, s. 553; Oğuzman/ Seliçi/Oktay-Özdemir, s. 635.

14 Feyzioğlu, s. 174; Tekinay, s. 39; Taman Şıpka, s. 40; Oğuzman/Seliçi/OktayÖzdemir, s. 632; Erkan, s. 31; Eren, s. 109. 
işlemin yapılması hâllerinde kullanılabilir". Buna karşılık, yasal önalım hakkını düzenleyen TMK m. 732'ye göre önalım hakkının kullanılması için paydaşın payının tamamını veya bir kısmını üçüncü kişiye satması gereklidir. Hal böyle olunca, yasal önalım hakkının sadece satış halinde mi kullanılabileceği, yoksa sözleşmesel önalım hakkında olduğu gibi, satışa eşdeğer işlemlerde de söz konusu olup olmayacağı hususunun değerlendirilmesi gerekmektedir. Kanaatimizce, sözleşmesel önalım hakkına ilişkin bu esasın, yasal önalım hakkında geçerli olmaması için bir sebep yoktur ${ }^{15}$. GÜMÜŞ, TBK m. 240 ile TMK m. 732 arasında bir atıf köprüsü kurulmadığı için, burada örtülü bir kanun boşluğu olduğunu ve bu boşluğun ekonomik bakımdan satışa eşdeğer işlemlerin yasal önalım hakkı bakımından da önalım olayı kabul edilerek doldurulması gerektiğini ifade etmektedir ${ }^{16}$.

Önalım olayı, satış sözleşmesi veya ekonomik açıdan satışa eş değer ${ }^{17}$ olan bir hukuki işlemdir. Ekonomik açıdan satışa eş değer bir hukuki işlem de, iradi (isteğe bağl1), ivazlı, bir bedel karşıllı̆ında mülkiyetin devrinin amaçlandığı cüz'i halefiyet şeklinde gerçekleşmelidir ${ }^{18}$. Belirtmek gerekir ki, bazı satışlarda Yargıtay önalım hakkının kullanımına izin vermemektedir. Yargıtay uygulamasına göre önalım hakkının kullanılamayacağı halleri sonraki bölümde ${ }^{19}$ değerlendireceğiz.

15 Tekinay, s. 40; Oğuzman/Seliçi/Oktay-Özdemir, s. 632-635; Eren, s. 110 vd.; Sirmen, s. 458-459; Erkan, s. 39; Gümüş, s. 452; Aydın Ünver, Tülay: "Yasal Önalım Hakkında Önalım Olayının Bildirilmesi”, Bahçeşehir Üniversitesi Hukuk Fakültesi Dergisi, C. 11, S. 145-146, Eylül Ekim 2016, Prof. Dr. Özer SELİÇİ'nin Anısına Armağan, s. 834. Aksi yönde Sebük, s. 85; Feyzioğlu, s. 185; Taman Şıpka, s. 48; Karş. Aybay/Hatemi, s. 194 ve Ayan, s. 390 vd.

16 Gümüş, s. 452.

17 Bu hususta bkz. Baygın, Cem: "Yeni Borçlar Kanununun Satış İlişkisi Doğuran Haklar Konusunda Getirdiği Düzenlemelere Genel Bir Bakış”, Bahçeşehir Üniversitesi Hukuk Fakültesi Kazanc1 Hakemli Hukuk Dergisi, Y. 2011, S. 79-80, s. 7 vd.

18 Sirmen, s. 447 ve s. $458-459$. Ayrıca bkz. bu yönde Tekinay, s. 22 ve s. 40; Gürsoy/ Eren/Cansel, s. 616-617; Kurca, s. 1184-1185; Erkan, s. 38-39; Eren, s. 110 vd; Oğuzman/Seliçi/Oktay-Özdemir, s. 632-635; Akalp-Demirtabak, s. 53; Kırkbeşoğlu, s. 72-73. İsviçre hukuku için bkz. Meier-Hayoz, Art. 682, N. 58; Rey/Strebel, Bas.Kom., Art. 681, N. 6. Aksi yönde Sebük, s. 85; Feyzioğlu, s. 185; Taman Şıpka, s. 48-50. Karş. Ayan, s. 390 vd.; Aybay/Hatemi, s. 194. Geniş bilgi için bkz. Kizir, Mahmut: "6098 Sayılı Türk Borçlar Kanununa Göre Satış İlişkisi Doğuran Haklar ve Özellikle Önalım Hakkına İlişkin Hükümlerin Değerlendirilmesi”, Marmara Üniversitesi Hukuk Fakültesi Hukuk Araştırmaları Dergisi, C. 22, S. 3, 2016, Prof. Dr. Cevdet YAVUZ'a Armağan, s. 1770 vd.; Okur, Sinan: “Önalım Olgusuna Dair Yeni Bir Kategori; Ekonomik Bakımdan Satışa Eşdeğer İşlem Kavramı Üzerine Mukayeseli Bir İnceleme (TBK m. 240/Art. 216c OR)”, SDÜHFD C.9, S. 1, Y. 2019, s. 101 vd.

19 Bkz. I, C, 1 ve 2. 
Satış işleminin önalım olayını gerçekleştireceği açıktır. Ancak cebri artırmayla satışlarda kanunun açık hükmü gereği önalım hakkı kullanılamaz (TMK m. 733/1). Buna karş1lı isteğe bağlı (ihtiyari) özel artırma veya açık artırmayla yapılan satı̧larda önalım hakkı kullanılabilir ${ }^{20}$. Alım ve geri alım haklarının kullanılmasıyla hak sahibi ile muhatap arasında satım ilişkisi doğmaktadır. Dolayısıyla bu hakların kullanımıyla ortaya çıkan satış ilişkisi de önalım olayı teşkil eder ${ }^{21}$. Taşınmaz satış vaadinin önalım olayı kabul edilip edilmeyeceği tartışmalıdır ${ }^{22}$. Yargıtay, tapu kütüğünün ayrı bir sayfasına kaydedilmiş bağımsız ve sürekli üst hakkının satımında önalım hakkının kullanılabileceğini kabul etmiştii ${ }^{23}$. Keza ifa yerine geçen edim de satım teşkil edebilir ${ }^{24}$. Buna karşıllk, mülkiyeti devir borcu doğuran bağış ${ }^{25}$ ve trampada önalım hakkı kullanılmaz ${ }^{26}$.

20 Feyzioğlu, s. 238-239; Tekinay, s. 22; Gürsoy/Eren/Cansel, s. 616; Taman Şıpka, s. 81; Kırca, s. 1184; Eren, s. 113; Ertaş, s. 394; Erkan, s. 61; Akalp-Demirtabak, s. 71; Kırkbeşoğlu, s. 53.

21 Sebük, s. 147; Feyzioğlu, s. 118 vd.;Tekinay, s. 22-23; Taman Şıpka, s. 84-85; Eren, s. 114; Erkan, s. 64. Bu hakların önalım olayı oluşturmaları hususunda ayrıntılı bilgi için bkz. Erkan, s. 64 vd.

22 Taşınmaz satış vaadini önalım olayı kabul etmeyen görüş için bkz. Feyzioğlu, s. 187 ve s. 284; Taman Şıpka, s. 60-61; Ertaş, s. 394; Oğuzman/Seliçi/Oktay-Özdemir, s. 613. Aksi görüş için bkz. Meier-Hayoz, Art 681, N. 59; Tekinay, s. 23-24; Gürsoy/Eren/ Cansel, s. 616; Eren, s. 113; Erkan, s. 64. Karş. Ayan, s. 392. Bu yöndeki Yargitay kararları için bkz. 14. HD, 2016/9475 E., 2019/6869 K., 21.10.2019 T.; 14. HD, 2016/ 5110 E., 2019/2835 K., 27.03.2019 T., Ruhi/Ruhi, s. 132-135. (Yollama yapilan kararlarda satış vaadi ile birlikte arsa payı karşılığı inşaat sözleşmesi yapılması söz konudur). Ancak hemen belirtelim ki, taşınmaz satış vaadi borçlusuna karşı dava açılıp da mülkiyetin geçmesine karar verildiğinde bu şekilde gerçekleşen işleme karşı önalım hakkı kullanılabilir. Bkz. Taman Şıpka, s. 61; Sirmen, s. 447. YHGK, 1978/6-672 E., 1979/ 477 K., 16.05.1979 T. (http://www.kazanci.com.tr/. Erişim tarihi: 19.10.2020); 6.HD, 7579 E,; 7797 K., 06,07.1993 T. (Karahasan, Mustafa Reşit: Yeni Türk Medeni Kanunu Eşya Hukuku, 1. Cilt, Arıkan Basım Yayım, İstanbul, 2007, s. 1120).

23 Eren, s. 114. Bu yönde bkz. 6. HD, 2007/13277 E., 2008/323 K., 21.01.2008 T. (http://www.kazanci.com.tr/. Erişim tarihi: 19.10.2020)

24 Meier-Hayoz, Art. 682, N. 59; Rey, N. 1257; Eren, s. 114; Sirmen, s. 606.

25 Feyzioğlu, s. 256; Taman Şıpka, s. 87-88; Tekinay, s. 22; Gürsoy/Eren/Cansel, s. 616; Eren, 114; Ertaş, s. 394; Sirmen, s. 458; Ayan, s. 390; Erkan, s. 66; AkalpDemirtabak, s. 78; Oğuzman/Seliçi/Oktay-Özdemir, s. 613.

26 Feyzioğlu, s. 245; Tekinay, s. 22; Gürsoy/Eren/Cansel, s. 616; Eren, s. 114; Sirmen, s. 448; Ayan, s. 390; Erkan, s. 68; Akalp-Demirtabak, s. 77; Kırkbeşoğlu, s. 70-71. Karş. Taman Şıpka, s. 91; Oğuzman/Seliçi/Oktay-Özdemir, s. 614; Aydın Ünver, s. 841-842; Rey/Strebel, Bas.Kom., Art. 681, N. 6; Von Fischer Lehmann, Marie: ZGB Kommentar, Schweizerisches Zivilgesetzbuch, OFK - Orell Füssli Kommentar, 2016, Art. 681, N. 3 (https://www.swisslex.ch/) (Erişim tarihi: 30.09.2020). 
Bundan başka, satış ya da satışa eşdeğer işlemin geçerli olması gerekir. Sözleşmenin geçerlilik şartlarında eksiklik söz konusu ise, eksikliğin türüne göre, kesin hükümsüzlük (butlan) veya iptal edilebilirlik yaptırımları söz konusu olacak ve bu halde önalım olayı gerçekleşmeyecektir ${ }^{27}$. Her türden hukuki işlem için aranan geçerlilik koşulları ehliyet, işlemin konusunun emredici hukuk kurallarına, hukuka, ahlaka, kamu düzenine, kişilik haklarına aykırı ve konusunun imkânsız olmamasıdır. Keza irade beyanlarında muvazaa olmamalıdır. Bu ifade edilen koşullardaki eksiklik işlemin kesin hükümsüz olması sonucunu doğurur. Öte yandan, işlemin taraflarının irade beyanlarının sağlıklı olması, bir başka ifadeyle yanılma, aldatma veya korkutmayla sakatlanmamış olması gerekir. Bundan başka, işlemde aşırı yararlanma (gabin) da olmamalıdır. İrade sakatlıkları ve aşırı yararlanmanın yaptırımı iptal edilebilirliktir ${ }^{28}$. Son olarak şekil şartı öngörülmüş işlemlerde -taşınmazın satışı kural olarak şekil şartına tabidir- bu şekle uyulmamasının yaptırımı da kesin hükümsüzlüktür ${ }^{29}$.

Biz çalışma konumuz çerçevesinde, sadece hukuki işlemde muvazaa halini müteakip başlığın altında ana hatlarıyla değerlendireceğiz.

\section{3. Özel Bir Durum: Önalım Olayında Muvazaa}

\section{a. Genel Olarak Muvazaa}

Muvazaa, iki tarafin iradeleriyle beyanları arasında isteyerek meydana getirdikleri bir uygunsuzluk halidir. Muvazaa, tarafların üçüncü kişileri aldatmak amacıyla, kendi iradelerine uymayan ve aralarında hüküm ifade etmeyecek bir görünüş yaratma hususunda anlaşmalarıdır ${ }^{30}$. Taraflar, yap-

27 Hukuki işlemin geçerlilik koşulları ve buna bağlı ortaya çıkan yaptırımlar için bkz. Oğuzman, Kemal/Barlas, Nami: Medeni Hukuk, 24. Baskı, Vedat Kitapçılık, İstanbul, 2018, s. 203 vd.; Oğuzman, Kemal/Öz, Turgut: Borçlar Hukuku Genel Hükümler, C. 1, 16. Bası, Vedat Kitapçılık, İstanbul, 2018, s. 80 vd.; Eren, Fikret: Borçlar Hukuku Genel Hükümler (BG), 24. Baskı, Yetkin Yayınevi, Ankara, 2019, s. 375 vd. Önalım hakk1 bağlamında spesifik değerlendirmeler için bkz. Feyzioğlu, s. 186 vd.; Taman Şıpka, s. 61 vd.; Erkan, s. 42 vd.; Akalp-Demirtabak, s. 54 vd.; Kırkbeşoğlu, s. 122 vd.

28 İptal edilebilirliğin türleri ve bu husustaki tartışmalar için bkz. Eren, BG, s. 387-389; Oğuzman/Barlas, s. 230 vd.; Kocayusufpaşaoğlu, Necip/Hatemi, Hüseyin/ Serozan, Rona/Arpacı, Abdülkadir: Borçlar Hukuku Genel Bölüm, Birinci Cilt, 6. Bası, Filiz Kitabevi, İstanbul, 2014, s. $580 \mathrm{vd}$.

29 Şekle aykırılık hususunda geniş bilgi için bkz. Altaş, Hüseyin: Şekle Aykırılığın Olumsuz Sonuçlarının Düzeltilmesi, Yetkin Yayınevi, Ankara, 1998, s. 101 vd.; Özbilen, Arif Barış: Sözleşmelerin Şekli ve Şekil Yönünden Hükümsüzlüğü, 1. Baskı, On İki Levha Yayınları, İstanbul, 2016, s. $248 \mathrm{vd}$.

30 Eren, BG, s. 394. Muvazaa hususunda bkz. Esener, Turhan: Türk Hususi Hukukunda Muvazaalı Muameleler, Ankara Üniversitesi Hukuk Fakültesi Yayınları, İstanbul, 1956, 
tıkları sözleşmenin hüküm doğurmaması konusunda veya yaptıkları sözleşmeden (görünürdeki işlemden) farklı bir sözleşmenin hüküm doğurması konusunda anlaşırlar. İlk halde, mutlak muvazaa (basit muvazaa), ikinci halde nisbi muvazaa (mevsuf muvazaa) söz konusu olur ${ }^{31}$.

Mutlak muvazaanın unsurları; görünürdeki işlem, muvazaa anlaşması ve aldatma kastı/ niyetidir. Görünürdeki işlem (muvazaalı işlem), tarafların üçüncü kişileri aldatmak için yaptıkları işlemdir. Taraflar hukuki işlemi sırf görünürde yapmaktadırlar, bu nedenle de aralarında hüküm ve sonuç doğurmayacağ1 konusunda anlaşmaktadırlar. Muvazaa anlaşması, tarafların görünürdeki işlemi sırf üçüncü kişileri aldatmak için yaptıklarına ve kendi aralarında hüküm ifade etmeyeceğine ilişkin olarak yaptıkları anlaşmadır. Mutlak muvazaanın üçüncü koşulu aldatma kastıdır. Sözleşmelerin yorumu, muvazaal işlemler kenar başlıklı TBK m. 19/1'e göre, "bir sözleşmenin türünün ve içeriğinin belirlenmesinde ve yorumlanmasında, tarafların yanlışlıkla veya gerçek amaçlarını gizlemek için kullandıkları sözcüklere bakılmaks1zın, gerçek ve ortak iradeleri esas alınır". Gizleme niyeti, ancak üçüncü kişilerin aldatılması ile söz konusu olabileceği için, aldatma kastı da muvazaanın unsurlarından biridir $^{32}$.

Nisbi (mevsuf) muvazaada, mutlak muvazaadaki unsurlardan başka bir de gizli işlem bulunur. Taraflar görünürdeki - muvazaalı işlemin altında kendi iradelerine uygun ve gerçekten istedikleri bir işlem yapabilirler. Görünürdeki işlemin arkasına gizlenmiş olan ve muvazaalı işlemin aksine taraflarca hüküm ve sonuç doğurması istenen bu işleme/ sözleşmeye gizli işlem denir. Örneğin saklı pay sahibi mirasçıdan mal kaçırmak için satış sözleşmesi arkasında yapılan bağış sözleşmesinde, satım sözleşmesi görünürdeki işlem, bağış sözleşmesi ise gizli işlemdir ${ }^{33}$.

s. 7 vd.; Aday, Nejat: Taşınmaz Mülkiyetinin Naklinde Muvazaa, 1. Baskı, Kazancı Hukuk Yayınları, İstanbul, 1992, s. 5 vd.; Atamulu, İsmail: Türk Borçlar Hukukunda Muvazaa, Adalet Yayınevi, Ankara, 2017, s. 22 vd.; Özkaya, Eraslan: Açıklamalı İçtihatlı İnançlı İşlem ve Muvazaa Davaları, 7. Baskı, Seçkin Yayınevi, Ankara, 2017, s. $182 \mathrm{vd}$.

31 Eren, BG, s. 395; Oğuzman/Öz, s. 129; Kocayusufpaşaoğlu/Hatemi/Serozan/Arpacı, s. 345-346; Tekinay, Selahattin Sulhi/Akman, Sermet/Burcuoğlu, Haluk/Altop, Atilla: TEKINAY Borçlar Hukuku (TEKINAY Borçlar), 7. Bask1, Filiz Kitabevi, İstanbul, 1993, s. 407; Esener, s.41-43; Aday, s. 5 ve s. 12 vd.; Atamulu, s. 46-47.

32 Eren, BG, s. 397; Esener, s. 25; Kocayusufpaşaoğlu/Hatemi/Serozan/Arpacı, s. 345; Atamulu, s. 44-45. Aksi görüşte bkz. Aday, s. 9. Karş. Oğuzman/Öz, s. 128-129.

33 Eren, BG, s. 398; Oğuzman/Öz, s. 129; Kocayusufpaşaoğlu/Hatemi/Serozan/Arpacı, s. 346; Tekinay/Akman/ Burcuoğlu/Altop, TEKINAY Borçlar, s. 410; Esener, s. 42; Aday, s. 13 vd.; Atamulu, s. 51 vd. 
Muvazaanın hüküm ve sonuçlarına gelince, yukarıda da yer verdiğimiz üzere TBK m. 19/1 gereğince, bir sözleşmenin türünün ve içeriğinin belirlenmesinde ve yorumlanmasında, tarafların yanlışlıkla veya gerçek amaçlarını gizlemek için kullandıkları sözcüklere bakılmaksızın, gerçek ve ortak iradeleri esas alınacaktır. Muvazaalı yani görünürdeki işlemde tarafların arzusu işlemin hüküm doğurmamasıdır, kanun koyucu da tarafların gerçek ve ortak iradelerinin esas alınacağını ifade etmiştir. Baskın görüşe göre, muvazaalı yani görünürdeki işlem, hem taraflar, hem de üçüncü kişiler bakımından kesin hükümsüzdür. Buna karşılık, gizli işlem gerekli geçerlilik şartlarını taşıyorsa geçerli olacaktır ${ }^{34}$.

Muvazaalı işlemin hükümsüzlüğü, hâkim tarafından re'sen dikkate alınır. Kural olarak herkese karşı ve herkes tarafından ileri sürülebilir. Fakat belirtmek gerekir ki, bu kuralın mutlak uygulanmas1, ilgili ilgisiz herkese muvazaalı işlemin taraflarının sözleşme ilişkilerine orantısız müdahale imkânı verir. Dolayısıyla işlemin muvazaalı olduğunu ileri sürebilecek kişiler sınırlandırılmıştır. Öğreti ve uygulama muvazaalı işlemin geçersizliğinin ilgililer tarafından ileri sürülebileceğini kabul etmektedir ${ }^{35}$. Bu bağlamda, muvazaa, kural olarak, sözleşmenin taraflarınca birbirlerine karşı ileri sürülebileceği gibi, sözleşme taraflarınca üçüncü kişilere karşı da ileri sürülebilir, keza üçüncü kişiler de "ilgili” olmak kaydıyla sözleşmenin taraflarına karşı

34 Esener, s. 50 vd.; Aday, s. 21 vd.; Atamulu, s. 112 vd.; Ŏguzman/Öz, s. 130-132; Tekinay/Akman/Burcuoğlu/Altop, TEKİNAY Borçlar, s. 410; Kocayusufpaşaoğlu/ Hatemi/Serozan/Arpacı, s. 346. Bkz. YHGK, 2013/4-1016 E.; 2014/436 K.; 02.04.2014 T. (http://www.kazanci.com.tr/. Erişim tarihi: 31.03.2021). Muvazaalı işlemin yoklukla malul olduğu görüşü için bkz. ve karş. Eren, BG, s. 401; Kocayusufpaşaoğlu/Hatemi/Serozan/Arpacı, s. 354-355. İsviçre öğretisinde ve uygulamasında da hâkim görüş kesin hükümsüzlüktür. Bu hususta bkz. Wiegand, Wolfgang: Honsell, Heinrich/Vogt, Nedim Peter/Wiegand, Wolfgang: Basler Kommentar (Bas.Kom.) Obligationenrecht (OR) I, Art. 1-529, Basel, 2011, Art. 18, s. 183, N. 126. Bkz. BGE 96 II 383, 390. Yokluk görüşü için bkz. Keller, Max/Schöbi, Christian: Das Schweizerische Schuldrecht, Band I, Allgemeine Lehren des Vertragsrechts, Basel, 1988, s. 194; Kramer, Ernst A./Schmidlin, Bruno: Schweizerisches Zivilgesetzbuch Das Obligationenrecht, Band VI, 1. Abteilung Allgemeine Bestimmungen, Allgemeine Einleitung in das schweizerische Obligationenrecht und Kommentar zur Art. 1-18 OR, Bern 1986, Art. 18, N. 156-157. (Kramer, Ber.Kom.).Buna karş1lık Alman Hukukunda, Alman Medeni Kanunu'nda (Bürgerliches Gesetzbuch - BGB) muvazaalı işlemin kesin hükümsüz olduğu açıcça düzenlenmiştir. Bkz. BGB § 117/1.

35 Bu hususta bkz. Atamulu, s. 120; Atamulu, s. 120 ve dipnot 48'de yollama yapilan yazarlar. “... Diğer taraftan, görünüşteki hukuki işlemin muvazaa sebebiyle geçersiz bulunduğu iddiası, hukuken korunması gereken bir hakk1 bulunan üçüncü kişiler tarafından da ileri sürülebilir..." YHGK, 2013/19-1622 E., 2015/1238 K., 17.04.2015 T. (http://www.kazanci.com.tr/. Erişim tarihi: 31.03.2021) 
hükümsüzlük iddiasında bulunabilirler. Esasen bir kimsenin davacı sıfatını haiz olabilmesi de, dava konusu hukuki ilişkiden kaynaklanan bir menfaatinin bulunmasını gerektirir (HMK m. 114/1 b. h).

Kanun koyucu, doğrudan veya dolaylı olarak muvazaalı işlemin hükümsüzlüğünün ileri sürülemeyeceği istisnai haller de kabul etmiştir. Esasen muvazaalı işlemin geçersizliğine ilișkin açık bir hüküm mevzuatımızda olmadığı gibi, bu geçersizliğin ileri sürülemeyeceğine dair doğrudan ve genel bir hüküm de yoktur ${ }^{36}$. Ancak ifade edeceğimiz bazı hallerde muvazaalı işlemin hükümsüzlüğünün ileri sürülemeyeceği kabul edilmektedir.

Bu bağlamda, muvazaaya ilişkin doğrudan düzenleme getiren spesifik kanun hükmü TBK m. 19/2'dir. Buna göre, "Borçlu, yazılı bir borç tanımasına güvenerek alacağ 1 kazanmış olan üçüncü kişiye karşı, bu işlemin muvazaalı olduğu savunmasında bulunamaz". Bundan başka, doğrudan doğruya muvazaayı düzenlememekle birlikte, yine muvazaanın ileri sürülememesi sonucunu doğuran bir kanun hükmü TMK m. 1023'dür. Buna göre, “Tapu kütüğündeki tescile iyiniyetle dayanarak mülkiyet veya bir başka aynî hak kazanan üçüncü kişinin bu kazanımı korunur". Bu çerçevede tapuda yapılan muvazaalı devir sonucu malik olarak gözüken kişiden ayni hak iktisap eden iyiniyetli üçüncü kişinin bu kazanımı korunacaktır. Keza TMK m. 988'e göre de, "Bir taşınırın emin sıfatıyla zilyedinden o şey üzerinde iyiniyetle mülkiyet veya sınırlı aynî hak edinen kimsenin edinimi, zilyedin bu tür tasarruflarda bulunma yetkisi olmasa bile korunur". Bu bağlamda da, taşınır malı emin sıfatıyla zilyedinden edinen iyiniyetli üçüncü kişiye karşı muvazaa iddiası dermeyan edilemeyecektir. Bir diğer hal de, TBK m. 41/2 hükmü kapsamında ortaya çıkar. Buna göre, "Temsil yetkisi üçüncü kişilere bildirilmişse temsil yetkisinin içeriği ve derecesi, bu bildirime göre belirlenir". Şayet temsil olunan ve temsilci temsil belgesinin içeriğinin muvazaalı olması hususunda anlaşmışlarsa, temsil olunan bunu temsilciyle işlem yapan iyiniyetli üçüncü kişilere karşı ileri süremeyecek, bu kişilere bildirilen temsilin kapsamı geçerli olacaktır ${ }^{37}$.

Muvazaalı işlemin hükümsüzlüğünün ileri sürülemeyeceği son hal, hükümsüzlügü ileri sürmenin hakkın kötüye kullanımı teşkil etmesi durumudur. TMK m. 2/2'ye göre, “ Bir hakkın açıkça kötüye kullanılmasını hukuk düzeni korumaz". Bu bağlamda, muvazaalı işlemin hükümsüzlüğünün dermeyanının hakkın kötüye kullanımı teşkil etmesi halinde, esasen hükümsüz

36 Esener, s. 113-114 ve s. 119 vd.; Atamulu, s. 140-141; Aday, s. 24 vd.; Wiegand, Bas.Kom. OR I, Art. 18, s. 183, N. 126.

37 Bu hallere ilişkin geniş bilgi için bkz. Aday, s. 24 vd.; Atamulu, s. 140 vd. 
olan muvazaalı işlem geçerliymiş gibi hüküm ve sonuç doğuracaktır ${ }^{38}$. Zira hakkın kötüye kullanımını hukuk düzenin korumaması, hakkı kötüye kullananın bu şekilde elde etmeye çalıştığı amaca ulaşamaması anlamına gelir.

Hakkın kötüye kullanımının söz konusu olması için, hukuk düzeninin tanıdığı bir hakkın varlığı ve bu hakkın açıkça yani herkesin anlayabileceği -toplum içinde ortalama akıl ve düşünceye sahip kişilerin fark edebileceğiaçıklıkta kötüye kullanılması gereklidir. Bu kötüye kullanmadan bir zararın hâsıl olmasının gerekip gerekmediği tartışmalıdır ${ }^{39}$.

Kötüye kullanmaktan amaç, esas itibariyle hakkın amacına aykırı kullanımı ile hakkın kullanılmasında menfaat olmayışı olarak ifade edilebilir ${ }^{40}$. Öte yandan öğretide, hakkın kötüye kullanımı örneklerinin belirli şablonları ortaya konulmuştur ${ }^{41}$. Esasen bunlar da, amaca aykırı kullanım bağlamında ortaya çıkan hallerdir ${ }^{42}$. Hakkın amaca aykırı kullanımı çerçevesinde, örneğin bir babanın küs olduğu oğlunu annesinin kabrinin bulunduğu bahçesine sokmaması $^{43}$ hali örnek verilebilir. Babanın mülkiyet hakkı söz konusudur ve mülkiyet hakkı bağlamında bir kimsenin taşınmazına bir başkasının girmesine engel olması mümkündür. Bu mahremiyet isteğinden ileri gelebileceği gibi, sadece çimlerinin zarar görmesini istememesinden de ileri gelebilir. Fakat bu olay bağlamında mülkiyet hakkının kendisine tanıdığı yetkiyi kullanmasının sebebi, mahremiyet veya bahçesinin zarar görmesi kaygısı

38 Hakkın kötüye kullanımı hususunda bkz. Edis, Seyfullah: Medeni Hukuka Giriş ve Başlangıç Hükümleri, 4. Baskı, Ankara Üniversitesi Hukuk Fakültesi Yayınları, Ankara, 1989, s. 331; Zevkliler, Aydın/Acabey, Beşir/Gökyayla, Emre: Zevkliler Medeni Hukuk, 6. Baskı, Seçkin Yayınevi, Ankara, 1999, s. 185 vd.; Akyol, Şener: Dürüstlük Kuralı ve Hakkın Kötüye Kullanılması Yasağı, Filiz Kitabevi, İstanbul, 1995, s. 111 vd.; Oğuzman/Barlas, s. 284 vd.; Altaş, Hüseyin: Medeni Hukuk Başlangıç Hükümleri (TMK m. 1-7), Yetkin Yayınevi, Ankara, 2014, s. 287 vd.; Uyar, Talih: "Yargitay Kararlarında "Dürüstlük (Objektif İyiniyet)" Kuralı (MK.2/I) ve "Hakkın Kötüye Kullanılması Yasağı” (MK.2/II)", Prof. Dr. SEYFULLAH EDİS'E ARMAĞAN, İzmir, 2000, s. 441 vd.; Alaslan, Fatma: "Medeni Hukuk'da Dürüstlük Kuralı ve Hakkın Kötüye Kullanılması Yasağı”, Çankaya Üniversitesi Hukuk Fakültesi Dergisi, C. 1, S. 2, Ekim 2016, s. 413 vd., s. 424 vd. Ayrıca bkz. Ateş, Derya: "Sözleşme Özgürlüğü Yönünden Dürüstlük Kuralları”, TBB Dergisi, S. 72, 2007, s. 75 vd.

39 Ŏguzman/Barlas, s. 271; Serozan, Rona: Medeni Hukuk, Vedat Kitapçıllk, İstanbul, 2011, s. 160; Dural, Mustafa/Sarı, Suat: Türk Özel Hukuku, C. I, Filiz Kitabevi, 12. Bask1, İstanbul, 2017, s. 256. Karş. Edis, s. 329; Zevkliler/Acabey/Gökyayla, s. 184.

40 Şans Uçaryılmaz, Talya: Bono Fides (Dürüstlük Kuralı), Yetkin Yayınevi, Ankara, 2019, s. 151.

41 Serozan, s. 270-271.

42 Şans Uçaryılmaz, s. 151.

43 Serozan, s. 270. 
değil, oğlunu üzmektir. Mülkiyet hakkının tanınmasının sebebinin bu olmadığ 1 da açıktır. Bu noktada, amaca aykırı - yararsız hak kullanımı mevcuttur. Bunun yaptırımı, malik babanın elde etmek istediği amaca ulaşamaması biçiminde ortaya çıkacaktır. Yani oğlunun bahçesine girmesine mülkiyet hakkını ileri sürüp engel olamayacaktır. Nitekim benzer bir olayda Alman İmparatorluk Mahkemesi, malikin oğluna belli günlerde saatle sınırlı biçimde bahçeye girme hakkı tanımıştı ${ }^{44}$.

Muvazaanın ispatı hususuna gelince, bununla kast edilen, tarafların gerçek iradesinin, görünürdekinden farklı olduğunun ortaya konulmasıdır. Muvazaayı ispatlayacak olanlar sözleşmenin tarafları ise, onların Hukuk Muhakemeleri Kanunu (HMK) m. 200-201 hükümleri gereği, kural olarak yazılı delil göstermeleri gerekecektir ${ }^{45}{ }^{46}$. Buna karşılık, sözleşme taraflarının dışındaki üçüncü kişiler muvazaayı HMK m. 203/1 b. d'ye göre her türlü delille ispat edebilirler ${ }^{47}$.

\section{b. Önalım Hakkının Kullanılması Bağlamında Muvazaa}

Konumuzla bağlantılı olarak tarafların görünürde bir satım sözleşmesi yapmaları fakat gerçekte bu satımın hüküm ve sonuç doğurmayacağı hususunda anlaşmış olmaları halinde mutlak muvazaa söz konusu olacaktır. $\mathrm{Bu}$ ihtimalde taraflar muvazaalı satım işlemini önalım hakkı sahibini hakkını kullanması için harekete geçirmek ve onun önalım konusu malı çok defa yüksek bedelle satın almasını sağlamak amacıyla yapmaktadırlar ${ }^{48}$. Önalım hakkı sahibi, bu durumu dava sırasında öğrenirse davadan vazgeçip önalım hakkını kullanmaktan feragat edecektir ${ }^{49}$. Buna karşılık, hakkını kullandıktan

$44 \quad$ RGZ 72, 251.

45 Aday, s. 63 vd.; Atamulu, s. 205. Bkz. YHGK 2003/1-374 E., 2003/370 K., 28.05.2003 T. (http://www.kazanci.com.tr/. Erişim tarihi: 15.03.2021). Hemen belirtilim ki, yazılı delil dışındaki diğer kesin delillerle de ispat mümkündür. Bkz. 1. HD, 2013/8612 E., 2013/12448 K., 12.9.2013 T (http://www.kazanci.com.tr/. Erişim tarihi: 15.10.2021). Ayrica bkz. 3. HD, 2014/413 E., 2014/7545 K., 15.5.2014 T. (http://www.kazanci. com.tr/. Erişim tarihi: 15.10.2021).

46 YIBBK, 5.2.1947 T., 20 E., 6 K. (07.07.1947 T. ve 6651 S. RG).

47 Aday, s. 66 vd.; Atamulu, s. 212 vd. Belirtmek gerekir ki, her ne kadar uygulamada ve öğretide muvazaa iddiasının üçüncü kişilerce her türlü delille ispat edilebileceği kabul görmekte idiyse de, mülga 1086 sayılı Hukuk Usulü Muhakemeleri Kanununda, mevcut 6100 say1lı Hukuk Muhakemeleri Kanunu m. 203/1 b. d gibi bir hüküm mevcut değildi. Bkz. Atamulu, s. 214.

48 Feyzioğlu, s. 420; Taman Şıpka, s. 71; Özenli, s. 131; Erkan, s. 51; AkalpDemirtabak, s. 60; Kırkbeşoğlu, s. 128-129.

49 Taman Şıpka, s. 71; Erkan, s. 51. 
sonra muvazaayı öğrenirse ne olacaktır? Bu soruya verilen cevapların ilki, önalım hakkı sahibinin aldatma (hile) hükümlerine istinaden muvazaayı öğrenmesinden itibaren bir yıl içinde iptal hakkını kullanıp bedel iadesi talep etmesidir $^{50}$. Bir diğeri ise, aldatma (hile) hükümlerine istinaden değil yanılma (hata) hükümlerine istinaden önalım hakkı beyanının iptali ve bedelin iadesidir ${ }^{51}$. Bu iki cevap arasında sonuca etkili olan fark, aldatma halinde sözleşmeye icazet verilmesinin tazminat hakkına halel getirmemesidir ${ }^{52} . \mathrm{Bu}$ husustaki bir diğer görüşe göre ise, önalım hakkı kullanılıp tescil yapılmışsa, ancak satım sözleşmesinde muvazaa varsa, bu sözleşmeye istinaden önalım hakkı sahibi lehine yapılan tescil de yolsuzdur. Bu yolsuzluğu üçüncü kişiler de, önalım hakkı sahibi de ileri sürebilir, aldatma veya yanılma hükümlerine başvurmaya gerek yoktur ${ }^{53}$.

Tarafların görünürde taşınmaz payının devrini sağlayan bir sözleşme, örneğin bağış veya trampa yapmaları fakat gizli işlem olarak satım bağıtlamaları halinde, önalım hakk1 sahibi hakkını kullanabilecek midir? $\mathrm{Bu}$ soruya, gerek öğreti, gerekse Yargitay ${ }^{54}$ olumlu cevap vermektedir. Yani

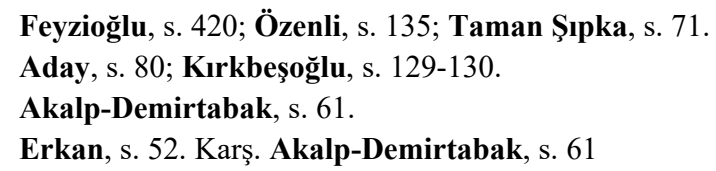
taşınmaz arasındaki değer farkının beş katına yakın olduğu görülmüşü̈r. Her ne kadar, trampaya konu edilen taşınmazlar arasındaki değer farkı tasarrufun yalnız başına satış olduğunu göstermeye yeterli değil ise de; davalının trampa sebebiyle devrettiği taşınmaz payını, iki aydan daha az bir süre içerisinde, aynı değer üzerinden, üç kez el değiştirdikten sonra dördüncü intikalde tekrar almış olması; davalının, 12.01 .2010 ve 14.01.2010 tarihli işlemlerde taşınmaz payını satın alan ve satan sıfatı ile T... Inş. San. Tic.A. Ş.'nin ortağı ve temsilcisi olarak işlemde yer alması gözetildiğinde, bu temlik işleminin davacının önalım hakkın kullanmasını engellemeye yönelik olduğunu kabul etmek gerekmiştir. Gerçekte satış olan işlemin sırf diğer paydaşların önalım haklarını kullanmalarının engellenilmesi için trampa olarak gösterilmesi halinde kanunun dolanılması söz konusu olur ki, bu hususu kanun korumaz. Öyle ise, yerel mahkeme direnme kararı gerekçesinde de belirtildiği üzere, davalı A. tarafindan, taşınmazda trampa yolu ile pay edinimi muvazaal olup, gerçekte satış işlemi ile pay edindiği ve davacı yan yönünden önalım hakkının var olduğu kabul edilmelidir. Yerel mahkemenin direnme kararl yerindedir. Yukarıda açıklanan nedenlerle, usul ve yasaya uygun bulunan direnme kararının onanması gerekir..." YHGK, 2013/6-109 E., 2013/1476 K., 23.10.2013 T., Günay, s. 225-228. Benzer bir karar için bkz. 6. HD, 2004/4 E., 2004/1054 K., 24.02.2004 T., Yıldız, s. 140-141. Hibenin gerçek satış olduğu yönünde bkz. 6. HD, 1985/14055 E., 1986/399 K., 21.1.1986 T. (http://www.kazanci.com.tr/. Erişim tarihi: 19.10 .2020$)$. 
önalım hakk1 sahibi, hakkını kullanabilecektir. Bununla birlikte, bu sonuca ulaştıran gerekçeler farklıdır. Bir görüşe göre, bu halde kanuna karşı hile vardır, tarafların önalım hakkının kullanımına engel olmak için muvazaalı işlem yapmaları, önalım hakkı sahibi bakımından kanuna karşı hile teşkil edecektir $^{55}$. Baskın görüşe ${ }^{56}$ göre ise, önalım hakkı sahibi görünüşte tapuda yapılan işlemin muvazaalı olduğunu, asıl gerçekleştirilmek istenen işlemin satış olduğunu dermeyan ederek önalım hakkını kullanabilecektir. Bu iddia karşısında, muvazaalı ișlemin taraflarının gizli işlemin şekle aykırılık sebebiyle geçersizliği ileri sürmesi hakkın kötüye kullanımı teşkil edeceği için dinlenmeyecektir ${ }^{57}$. Hal böyle olunca, önalım hakk1 sahibi geçerli bir satım sözleşmesi varmış gibi önalım hakkını kullanabilecektir. Öte yandan, önalım hakkı sahibi iddiasını da her türlü delille ispat edebilecektir ${ }^{58}$. TAMAN ŞIPKA, bu hususta hangi yoldan gidilirse gidilsin sonuçta önalım hakkının kullanılabileceğini, önalım hakkı sahibi muvazaaya dayandığında, muhatabın geçersizlik iddiasının hakkın kötüye kullanılması sayılıp geçerli bir satış varmışçasına önalım hakkının kullanılacağını ifade etmektedir ${ }^{59}$.

Öte yandan, nisbi muvazaa halinin görünürde bir satım sözleşmesi yapıldığı fakat gizli işlem olarak önalım hakkı kullanılması mümkün olmayan bir devrin -örneğin bağış sözleşmesi- gerçekleştirildiği halde, kullanılıp kullanılamayacağı sorusuna baskın görüş ${ }^{60}$ ve Yargitay uygulaması ${ }^{61}$ olumlu

55 Tekinay, s. 25. Karş. Esener, s. 98.

56 Feyzioğlu, s. 415-417; Özenli, s. 133; Aday, s. 79-80; Ertaş, s. 394; Erkan, s. 54. Karş. Sebük, s. 87 ve Atamulu, s. 244-245.

57 Burada görünürdeki işlem muvazaalı olduğu için, gizli işlem ise şekle aykırılık sebebiyle hükümsüzdür. Esasen hükümsüzlüğü ileri sürmek haktır, ancak bu hakkı kullanmak yani hükümsüzlüğ̈̈ dermeyan etmek, bu hakkın amaca aykırı kullanımı yani kötüye kullanımıdır. Nihayetinde hükümsüzlüğün sonucu işlemin herkes için, yani ilgili üçüncü kişiler - önalım hakkı sahibi paydaş için de, hükümsüz olması ve bu bağlamda önalım hakkı sahibinin de hükümsüz işleme istinaden önalım hakkını kullanamamasıdır. Fakat burada işlem taraflarının üçüncü kişileri aldatma amacıyla muvazaalı işlem yapmaları, bundan başka hükümsüzlüğe de kendilerinin sebep olması söz konusudur. Önalım hakkı sahibinin gerçekte yaptıkları/yapmak istedikleri işlemin bağış değil satım olduğunu kanıtlaması karşısında, satımın hükümsüzlüğünü ileri sürmek, kanaatimizce, kendi hukuka aykırı davranışlarıyla sebep oldukları hükümsüzlüğü ileri sürmeleri anlamına gelir ve bu nedenle hakkın kötüye kullanımı teşkil eder.

58 Feyzioğlu, s. 415-417; Özenli, s. 133; Aday, s. 79-80; Ertaş, s. 394; Erkan, s. 54. Karş. Sebük, s. 87 ve Atamulu, s. 244-245.

59 Taman Şıpka, s. 75.

60 Sebük, s. 88; Feyzioğlu, s. 418-419; Taman Şıpka, s. 73; Erkan, s. 55. Karş. Aday, s. 82.

61 Hemen belirtelim ki, bilahare yer vereceğimiz üzere Yargıtay 27.03.1957 tarihli içtihadı birleştirme kararıyla akrabaya yapılan temliklerin tapuda satış gösterilmiş olsa bile 
yanıt vermektedir. Yani bu halde önalım hakkı sahibi hakkını kullanabilecek, buna karşı muvazaalı işlemin tarafları, muvazaayı yani satım değil de bağış yaptıklarını ve hatta bunun da şekle aykırılık sebebiyle hükümsüz olduğunu, önalım hakkı sahibine karşı dermeyan edemeyeceklerdir. Zira bu iddia da hakkın kötüye kullanımı teşkil edecektir ${ }^{62}$. Kanaatimizce, satış işleminin önalım hakkının kullanılmasını engellemek için bağış gösterilmesi ve bu durumun önalım hakkı sahibi tarafından ispatlanması karşısında, muvazaalı işlemin taraflarının hükümsüzlük dermeyan etmesinde hakkın kötüye kullanımının söz konusu olduğu açıktır. Buna karşılık, bağışın veya önalım hakkı kullanımının mümkün olmadığı bir devir işleminin, satış olarak gösterilmesi halinde, önalım hakkını kullanan paydaşa karşı, muvazaalı işlemin taraflarının muvazaa dermeyanında bulunduğu her halde, hakkın kötüye kullanımı olduğu söylenemez. TAMAN ŞIPKA, görünürde satış sözleşmesi yaptıkları halde gerçekte bağı̧̧ yaptıkları iddiasının önalım hakkını engellemeye çok elverişli olduğunu, tarafların muvazaa iddialarını üçüncü kişi olan önalım hakkı sahiplerine ileri sürmeleri olanağı bir kez kabul edildiğinde, artık her satış olayında tarafların anlaşıp satışı bağış şeklinde göstermeleri mümkün olacağından, önalım hakkının kullanılmasının kötü niyetle engelleneceğini, bu nedenle gerçekte bağış işlemi yaptıkları yönündeki iddianın hakkın kötüye kullanılması olarak nitelendirilmesi halinde, tarafların iyiniyete uymayan davranışlarından bizzat kendilerinin yararlanması yolunun kapanmış olacağını ifade etmektedir. Bu kaygı yerinde olmakla birlikte, verilen

gerçekte miras hukukuna ilişkin amaçlarla yapılması veya bağış olması halinde önalım hakkının kullanılamayacağını kabul etmiştir. Bu YİBK saklı kalmak kaydıyla, Yargıtay, görünürde satım fakat gerçekte bağış veya önalım hakkının doğmayacağı başkaca bir temlikin yapıldığı hallerde, önalım hakkının kullanılabileceğini kabul etmektedir. Örnek olarak bkz. “... Her ne kadar davalı bu intikalin gerçekte satış şeklinde olmadı̆̆ını ileri sürmüşse de, kendisi o resmi akdin tarafi olduğundan akdin mahiyeti hakkındaki muvazaa iddiası dinlenemez. Intikal satış suretiyle olduğuna satıcı ile davalı arasındaki diğer ilişkilerin davacının şuf'a hakkına etkisi olmadığına ve yine davacı ile satıcının akraba durumunda olmalarının önemi bulunmadığına göre kararda sözü edilen Iç̧tihadı Birleştirme Kararının oluşa uygunluğu da mevcut değildir...” 6. HD, 6896/7221, 11.07.1995 T., Tunaboylu, s. 312. “...Dava konusu pay 16.2.2012 tarihli resmi senet ile H. Y. tarafindan davalıya satılmıştır. Davalı her ne kadar tapuda satış olarak gösterilen işlemin H. Y.' '̇n kooperatife üye olması için peşin ödemesi gereken aidat bedeline mahsuben devralındı̆̆ını savunmuş, gerçek bir satış olmadığından önalım hakkı doğmadığını bildirmiş ise de tapudaki resmi işlemin tarafi olup üçüncü kişi konumundaki davaclya karşı kendi muvazaasına dayanamaz..." 14. HD, 2014/4011 E., 2014/9348 K., 11.07.2014 T., Günay, s. 221-222.

62 Sebük, s. 88; Feyzioğlu, s. 418-419; Taman Şıpka, s. 73; Erkan, s. 55. Karş. Aday, s. 82 . 
örnekte gerçekte de satış yaptıkları yani gizli işlem olarak bağış yapmadıkları halde, tarafların gerçeğe aykırı olarak satış değil bağış yapmış olduklarını ifade etmeleri ihtimali gözetilmiştir. Fakat bu durumda zaten muvazaa yoktur, muvazaa olmadığ lük ileri sürmek söz konusudur ki, bu halde teknik anlamda kötüye kullanılabilecek bir hak da yoktur. Hükümsüz olup da bunu ileri sürmek değil, muvazaalı olmadığı - hükümsüz olmadığı halde açıkça yalan beyanla hükümsüzlük iddiasında bulunmak söz konusudur. Buna karşıllk, gerçekte bağış yaptıkları halde, tapuda satış gösterilmesi halinde muvazaa vardır. Önalım hakkı sahibinin hakkını kullanması üzerine alıcının (gerçekte bağışlananın), satım değil bağış olduğunu ileri sürmesi hakkın kötüye kullanımı teşkil ediyorsa, hiç şüphesiz bu iddia dinlenmeyecektir. Fakat bu iddianın, gerçekteki satışın bağış gösterilmesinde ve bu muvazaanın ileri sürülmesinde olduğu gibi verili biçimde kabul görmemesi gerekir. Tarafların burada önalım hakkı sahibinin, hakkını kullanamamasını amaçlamaları da söz konusu değildir, zira öyle olsaydı önalım hakkı kullanılmasına imkân vermeyen bağış1 satış gösterme yolu tercih edilmezdi. Öte yandan, ispat güçlüğü dikkate alındığında çok defa ispat faaliyetinin gerçekleştirilememesinden mütevellit önalım hakkı sahibi her şeye rağmen önalım hakkı kullanma olanağına kavuşacaktır. Dolayısıyla direkt olarak hakkın kötüye kullanımı vardır demek yerine hakkın kötüye kullanımını şartlarının dikkatle gözetilmesi, ancak ondan sonra -yani bir ön kabul olarak ya da verili biçimde değil- bu sonuca varılması gerektiği kanaatindeyiz ${ }^{63}{ }^{64}$.

63 Bu hususta bkz. Aday, s. 82. Krş. Taman Şıpka, s. 73, dipnot 135.

64 Örneğin daha önce yollama yaptığımız Yargıtay 14. Hukuk Dairesinin 2014/4011 E., 2014/9348 K., 11.07.2014 T. sayılı kararındaki ifadeler şu şekildedir: “... Davacı vekili 21.1.2013 tarihli dilekçesi ile paylı malik olduğu Susuz Köyü 63380 ada 4 Sayılı 4000 m2 arsa cinsli taşınmazın diğer paydaşı olan H. Y.'ın 22612/400.000 payını 16.2.2012 tarihinde davalı kooperatife 4000 TL bedel ile sattığını, beyanla önalım hakkına dayalı olarak tapu iptali ve tescil istemiştir. Davalı, gerçekte payın satın alınmadığını, kooperatif üyesi olan $H$. Y.'ın üyelik pesinatına mahsuben pay devri vapıldığını gercek bir satıs olmadığından davanın reddini savunmuștur. Mahkemece, davalı tarafindan sunulan, kooperatif kayıtlarından tașinmaz payın satan $H$. Y.'In davalı kooperatifin ortağı olduğu, Ankara 11. Noterliğinin 25.1.2008 tarih ve 01546 vevmive numaralı "taahhütname"den H. Y.'ın kooperatif ortaklığına kabulü halinde davava konu tașınmazdaki payın kayıtsız sartsız devredeceğini taahhüt ettiği kural olarak kişinin kendi muvazaasına dayanması mümkün değil ise de, davalı kooperatifin muvazaa iddiasında bulunmadı̆̆ı, tapuda gösterilen satışın gerçekte bir satış olmadı̆̆ını savunma olarak ileri sürdüğü ve buna dair inandırıcı belgeler sunduğu gerekçesiyle davanın reddine karar verilmişstir. Hükmü Davacı vekili temyiz etmiştir... Dava konusu pay 16.2.2012 tarihli resmi senet ile H. Y. tarafindan davaliya satılmıştır. Davalı her ne kadar tapuda satış olarak gösterilen işlemin H. Y. 'in kooperatife üye olması için peşin 
Muvazaa anlaşması görünürdeki işlemin tamamına veya bir kısmına ilişkin olabilir. İlk halde tam muvazaa, ikincisinde ise kısmi muvazaa söz konusu olur. Örneğin taraflar yaptıkları satış sözleşmesinde satış bedelini gerçek satış bedelinden daha düşük veya daha yüksek gösterirlerse, kısmi muvazaa söz konusu olur. Uygulamada en çok karşılaşılan nisbi muvazaa türü de esasen bedel muvazaası denilen bu türdür. Önalım hakkının kullanımı bağlamında da çokça ortaya çıkan bir haldir. Biz bedel muvazaasını spesifik olarak çalışmamızın ikinci bölümünde değerlendireceğiz.

\section{4. Önalım Davası}

Kullanılması kenar başlıklı, TMK m. 734/1'e göre, önalım hakk1, al1cıya karşı dava açılarak kullanılır. Hak sahibinin alıcıya karşı önalım hakkını kullanmak için açtığı ve sonucunda hâkimin dava konusu payın davaciya satımı ve davacı adına tesciline karar verdiği yenilik doğuran dava önalım davasıdır. Bu dava nitelik itibariyle yenilik doğuran bir davadır ${ }^{65}$. İsviçre Medeni Kanunu'nda ve 743 sayılı mülga Türk Medeni Kanunu'nda önalım hakk1 yenilik doğuran bir hakla kullanılırken, 4721 sayılı Türk Medeni Kanunu hakkın dava açılarak kullanılması zorunluluğunu getirmiş̧ir. Madde gerekçesine göre, dava açılması zorunluluğu getirilmesinin sebebi, yürürlükteki hükümlerin önalım hakkının dava dışı beyanla kullanılmasına olanak tanıması ancak buna rağmen bu beyanla istenilen sonucun elde edilebilmesinin sonuçta daima bir dava açılmasını gerektirmesidir.

Yenilik doğuran haklar kural olarak dava açmaya gerek olmaksızın muhataba varması gerekli bir irade beyanıyla hüküm ve sonuçlarını doğururlar. Bazı yenilik doğuran haklar ise, kamu düzeni veya üçüncü kişilerin korunabilmesi gibi nedenlerle yenilik doğurucu dava açmak yoluyla kullanılırlar. Bu sonuçların tarafların anlaşmasıyla doğması mümkün değildir.

ödemesi gereken aidat bedeline mahsuben devralındiğını savunmuş, gerçek bir satış olmadı̆̆ından önalım hakkı doğmadığını bildirmiş ise de tapudaki resmi ișlemin tarafi olup üçüncü kiși konumundaki davactya karșı kendi muvazaasına dayanamaz. Öte yandan, payın şirkete ayni sermaye olarak konulduğu da kanitlanamamıştır. Bu durumda mahkemece işin esası incelenerek sonucuna göre bir karar verilmesi gerekirken yazılı gerekçeyle davanın reddi doğru görülmemiştir... ” Bu kararda hakkın kötüye kullanıldığı söylenmeden işlem tarafının muvazaasına dayanamayacağı ifade edilmiştir ama - yukarıda da incelediğimiz üzere - böyle genel bir kural hukukumuzda yoktur. Öte yandan, karardan anlaşıldığı kadarıyla, taahhütname de dikkate alındığında önalım olayının gerçekleşip gerçekleşmediği de kanaatimizce tartışılır. Bu karar için bkz. Günay, s. 221222. (http://www.kazanci.com.tr/. Erişim tarihi: 25.04.2021).

65 Eren, s. 117; Oğuzman/Seliçi/Oktay-Özdemir, s. 635; Sirmen, s. 460. Bu hususta geniş bilgi için bkz. Köylüoğlu, Egemen: Önalım Davası, Ankara, 2011, Yayımlanmamış Doktora Tezi, s. 127 vd. 
Babalık davası, boşanma davası böyledir ${ }^{66}$. Ne var ki yasal önalım hakkı bakımından esas itibariyle böyle bir durum söz konusu değildir. Nitekim bu nedenle öğretide dava açma zorunluluğunun getirilmiş olması da eleştirilmektedir ${ }^{67}$.

Önalım davasının davacısı paylı mülkiyete konu taşınmazda payını üçüncü kişiye satan paydaşın, paydaş veya paydaşlarıdır. Davalısı ise önalım hakkına konu taşınmazda payı alan yani yeni maliktir. Yasal önalım hakkı paydaşlar arasında kullanılamaz, bu hak sadece üçüncü kişilere karşı kullanılabiliir $^{68}$. Kural olarak, önalım davasının davalısı satım veya satıma eşdeğer işlemden sonra tescil yapılmış olup olmamasına göre belirlenir. Tescil henüz yapılmamışsa satıcı paydaşa, tescil yapılmışsa alıcı yeni malike dava açılması gerekir. Ancak uygulamada satımın hemen ardından tescil yapıldığ 1 için bu davanın davalısı payı devralan yeni malik olacaktır ${ }^{69}$.

Bundan başka, önalım hakkının kanunda öngörülmüş bulunan hak düşürücü süreler içinde kullanılması gerekir. TMK m. 733/3 ve 4'e göre, "Yapılan satış, alıcı veya satıcı tarafından diğer paydaşlara noter aracılı̆̆ıyla bildirilir. Önalım hakkı, satışın hak sahibine bildirildiği tarihin üzerinden üç ay ve her hâlde satışın üzerinden iki yıl geçmekle düşer”. Alıcıya karşı bu süreler içinde dava açılmadığ 1 takdirde, önalım hakkı düşer. Bildirimin ${ }^{70}$ yapılmamış ve sürelerin geçmiş olması halinde, hakkı düşen paydaş tazminat davası ikame edebilir ${ }^{71}$.

TMK m. 734/2'ye göre, “Önalım hakkı sahibi, adına payın tesciline karar verilmeden önce, satış bedeli ile alıcıya düşen tapu giderlerini, hâkim tarafından belirlenen süre içinde hâkimin belirleyeceği yere nakden yatırmakla yükümlüdür". Bu çerçevede, önalım bedeli, önalım hakkı sahibi davacının, önalım borçlusuna ödemesi gereken bedeli ifade eder. Bu bedel, TMK m. 734/2 gereğince taşınmazın satış bedeli ve alıcıya düşen tapu giderleri toplamıdır ${ }^{72}$. Taşınmaz satış bedeli de, kural olarak, tapudaki akit hisse sahibi bulunan şahsa diğer bir hissenin üçüncü şahsa satılmast halinde o hisse müsterive neve mal olmus ise o miktar ile ve belli bir süre içinde satın almak salâhiyetini veren ayni bir hakttr..." YİBK, 20.06.1951 T., 13 E., 5 K. (07.11.1951 T. ve 7950 S. RG).
} 
tablosunda gösterilen bedeldir ${ }^{73}$. Davacı adına tescile karar verilmeden önce önalım bedelinin hâkim tarafından belirlenen süre içinde ve hâkimin belirleyeceği yere nakden yatırılması zorunludur ${ }^{74}$.

Davanın sonucunda hâkimin vereceği karar ile önalım hakkı sahibi paydaşla alıcı üçüncü kişi arasında kendiliğinden iki tür ilişki doğar. İlki davacı ile davalı arasındaki satış ilişkisi, diğeri ise mülkiyeti nakleden ilişkidir. Bu dava üzerine hâkimin vereceği kararın kesinleşmesiyle, mülkiyet alıcıdan önalım hakkı sahibine geçer ${ }^{75}$. Burada bir tescilsiz iktisap hali söz konusudur. Önalım hakkı sahibi bu kararla tapu memurundan tescilin yapılmasını talep edebilir. Bu talep herhangi bir zamanaşımı veya hak düşürücü süreye tabi değildir. Yapılacak tescil de kurucu değil açıklayıcı mahiyette olacak$\operatorname{tir}^{76}$.

\section{Yargıtay Uygulamasına Göre Yasal Önalım Hakkının Kullanılamayacağı Haller}

\section{Fiili Taksim}

Yargıtay'ın müstakar hale gelmiş uygulaması bağlamında, paylı mülkiyete tabi olup da fiilen taksim edilmiş taşınmazlarda, paydaşlardan birinin payını devretmesi halinde diğer paydaşların önalım hakkını kullanmak istemesi hakkın kötüye kullanımı teşkil eder. Belirtmek gerekir ki, bu yönde, yani fiili paylaşma halinde yasal önalım hakkının olmadığı veya kullanılamayacağ1 yönünde herhangi bir kanun hükmü söz konusu değildir. Yargıtay, bu hususta bir içtihadı birleştirme kararı vermiş de değildir; ancak çok uzun zamandır istikrarlı bir şekilde bu içtihadını sürdürmektedir ${ }^{77}$.

73 6. HD, 1992/3754 E., 1992/4155 K., 23.3.1992 T. Ayrica bkz.6. HD, 2010/8834 E., 2011/442 K., 24.1. 2011 T. (http://www.kazanci.com.tr/. Erişim tarihi: 03.03.2021).

74 Eren, s. 123; Oğuzman/Seliçi/Oktay-Özdemir, s. 637-638. Madde gerekçesinde bu hususa ilişkin şu açıklama yapılmıştır: "Maddenin ikinci fıkrası, önalım bedelinin depo edilmesine ilişkin uygulamada kabul edilen esası kanun hükmü haline getirmektedir. Burada hak sahibinin satış bedeliyle birlikte, alıcıya düşen tapu giderlerinin hâkim tarafından belirlenen süre içinde ve belirlenen yere depo edilmesi öngörülmüştür. Önalım hakkı sahibinin depo edeceği bedelin, zaman zaman uygulamada sorunlar yaratan ve haksızlıklara yol açan banka teminat mektubu olarak da tevdi edilebilmesine son verilmiştir. Bedelin "nakden" yatırılması koşulu öngörüldügünden, nakit dışında yapılacak tevdiatlar geçerli kabul edilmeyecektir".

75 Eren, s. 124-125; Oğuzman/Seliçi/Oktay-Özdemir, s. 638; Sirmen, s. 461.

76 Eren, s. 125; Oğuzman/Seliçi/Oktay-Özdemir, s. 620; Sirmen, s. 461.

77 ÖZÇELIK'in tespit ettiği üzere, bu husustaki en eski HGK kararı 1988, özel daire kararı ise 1987 tarihlidir. Öte yandan 1981 tarihli bir HGK kararında karşı oy yazısında, 6. Hukuk Dairesinin uygulamasının 1980 yılından beri bu yönde olduğu ifade edilmiştir. 
Yargıtay uygulamasına göre, fiili taksimin söz konusu olması için, yasal önalım hakkına konu payın ilişkin bulunduğu taşınmazın paydaşlarca kendi aralarında taksim edilmiş ve taksim sonucu ortaya çıkan bölümlerin paydaşlara özgülenmiş olması gerekmektedir. Bu halde, bir paydaşın kendi payını devretmesi halinde diğer paydaşların önalım hakkını kullanmak istemesini Yargıtay hakkın kötüye kullanımı olarak görmektedir ${ }^{78}$.

Öğretide bir görüş Yargıtay'ın fiili taksime ilişkin uygulamasını isabetli bulurken $^{79}$, diğer bir görüş -deyim yerindeyse- bu uygulamaya şüpheyle yaklaşmaktadır ${ }^{80}$. Kanaatimizce de, taşınmazın fiilen taksim edildiği her olayda önalım hakkının kötüye kullanıldığını kabul etmek yerine her somut olay bakımından değerlendirme yapmak gerekir ${ }^{81}$.

\section{Miras Hukukuna İlişkin Amaçlarla Akrabaya Yapılan Devir}

Yargıtay 27.03.1957 tarih ve 12/2 sayı11 İçtihadı Birleştirme Kararıyla ${ }^{82}$ "Müssterek mülkün hissedarlarl, hisselerini karı ve kocaya, evlada veyahut akrabaya temlik etmeleri halinde şeklen satış akdi bulunsa bile hakikatte satıştan gayri miras hukukuna müteferri maksatların veya hibe gibi mülahazaların hâkim olduğu ahvalde Medeni Kanunun hakiki satışlarda kabul eylediği şuf'a hakkının cereyan etmeyeceği" ni kabul etmiştir.

Dolayısıyla Yargıtay kırk yıldır bu uygulamasını sürdürmektedir. Bkz. Özçelik, Barış: "Fiili Taksim Halinde Yasal Önalım Hakkının Kullanılamayacağı Yönündeki Yargıtay Uygulamasının Değerlendirilmesi”, TBB Dergisi, Mart-Nisan 2019, Sayı 141, s. 258, dipnot 15,16 ve 17 'de yollama yapilan kararlar.

78 Özçelik, s. 254 vd.; Sayımlar, Zeynep: "Yasal Önalım Hakkının Kullanılmasını Etkileyen Bir Durum Olarak Fiili Taksim”, İnönü Üniversitesi Hukuk Fakültesi Dergisi, Özel Say1, Y. 2015, C.1, s. 637 vd. Bu yöndeki kararlarına örnek olarak bkz. 14. HD, 2016/ 15682 E., 2020/4155 K., 29.06.2020 T.; 14. HD, 2016/14986 E., 2020/3422 K., 08.06.2020 T., Ruhi/Ruhi, s. 258-259 ve 276-277.

79 Tekinay, s. 45; Özenli, s. 75-79; Özdek, Yasemin: “Önalımda (Şuf”ada) Vazgeçme ve Bir Yargitay Kararı”, Dicle Üniversitesi Hukuk Fakültesi Dergisi, Y. 1985, C. 3, S. 3, s. 365.

80 Oğuzman, M. Kemal: "Dürüstlük Kuralına (MK m. 2) Başvurma Hususunda Bazı Yargitay Kararlarının Eleştirilmesi”, Prof. Dr. Yaşar KARAYALÇIN'A 65. Yaş Armağanı, Ankara, 1988, s. 414; Taman Şıpka, s. 117-118; Oğuzman/Seliçi/Oktay-Özdemir, s. 633, dipnot 1206 ve s. 642-643, dipnot 1242; Sirmen, s. 460; Erkan, s. 111; Köylüoğlu, s. 95-96; Sayımlar, s. 646; Kırkbeşoğlu, s. 206-207.

81 Oğuzman/Seliçi/Oktay-Özdemir, s. 642-643, dipnot 1242; Sirmen, s. 460; Erkan, s. 111; Köylüoğlu, s. 95-96; Sayımlar, s. 646; Kırkbeşoğlu, s. 206-207. Ayrıntılı değerlendirme için bkz. ve karş Özçelik, s. 259 vd.

82 Karar için bkz. RG 21.08.1957 T., 9687 S. 
Bu kararla birlikte Yargıtay, görünüşte satım sözleşmesi olsa bile gerçekte miras hukukuna müteferri amaçlarla bağış yapılması halinde, bir başka ifadeyle esasen muvazaanın söz konusu olduğu bu türden işlemlerde -gerçekte bir satım sözleşmesi olmadığı için- önalım hakkının kullanılamayacağını kabul etmiştir. Bu halde, Yargıtay, davalının muvazaayı ileri sürmesini de hakkın kötüye kullanımı olarak görmemektedir.

Öğretide de, çoğunlukla bu uygulama kabul görmektedir ${ }^{83}$. Öte yandan, Yargıtay burada akrabayı sadece mirasçılarla da sınırlandırmamaktadır ${ }^{84}$. Ancak öğretide akraba kavramının miras hukuku anlamında mirasçı sıfatı taşıyan akrabalar olarak anlaşılması gerektiğini ifade eden yazarlar da var$\mathrm{d}_{10}{ }^{85}$.

\section{YARGITAY UYGULAMASINA GÖRE ÖNALIM BEDELİ}

\section{A. Satış Bedelinin Değer Artışlarına Göre Mahkeme Tarafından Yeniden Belirlenmesi}

Yukarıda da ifade ettiğimiz üzere önalım bedeli, tapu kütüğünde/ akit tablosunda görünen satış bedeli ile alıcıya düşen tapu giderlerinin toplamıdır $^{86}$. Önalım bedeli, önalım hakkı sahibi davacının önalım borçlusuna ödemesi gereken bedeli ifade eder. Bu bedel, TMK m. 734/2 gereğince taşınmazın satış bedeli ve alıcıya düşen tapu giderleri toplamıdır. Davacı

83 İsviçre öğretisi ve uygulaması için bkz. Meier-Hayoz, Art. 681, N. 145; Rey, N. 1262; Rey/Strebel, Bas.Kom., Art. 681, N. 11. Türk hukuku ve uygulaması için bkz. Gürsoy/ Eren/Cansel, s. 616; Oğuzman/Seliçi/Oktay-Özdemir, s. 612; Sirmen, s. 459; Erkan, s. 75 ve dipnot 316 'da yollama yapılan yazarlar. Yargitay kararları için bkz. 14. HD, 2016/15429 E., 2020/2034 K., 20.02.2020 T.; 14. HD, 2016/8066 E., 2019/6219 K., 03.10.2019 T.; YHGK 2013/2268 E., 2015/1437 K., 27.05.2015 T., Ruhi/Ruhi, s. 314315, s. 408-410, s. 1154-1158.

84 “... Yargltay Hukuk Genel Kurulunun 08/02/2012 gün ve 2011/6-762 Esas, 2012/56 sayll ilamı Yargitay Hukuk Genel Kurulunun 27/04/2011 gün ve 2011/6-38 Esas sayll 2011/225 Karar sayll ilamı, Yargıtay Hukuk Genel Kurulunun 2011/6-164 Esas ve 2011/245 sayılı ilamlarında da satışın satış tarihi itibariyle doğrudan mirasçılar arasında yapılması gerekmeyip temlikin taraflarının akraba olmasının yeterli olduğuna karar verilmiştir...”, 14. HD, 2016/8066 E., 2019/6219 K., 03.10.2019 T., Ruhi/Ruhi, s. $408-410$.

85 Feyzioğlu, s. 270; Arık, K., Fikret: “Mirasçıya Satışta Suf'a Cereyan Eder mi?”, Ankara Üniversitesi Siyasal Bilgiler Fakültesi Dergisi, C. 12, S. 4, s. 214; Erkan, s. 75.

86 Bkz. Yukarıda s. 16, dipnot 72. Bu yöndeki yeni tarihli kararlar için bkz. 14. HD, 2016/ 15432 E., 20202/3282 K., 3.6.2020 T.; 14. HD, 2016/14449 E., 2020/3353 K., 4.6.2020 T.; 14. HD, 2018/5673 E., 2016/6186 K., 3.10.2019 T. (http://www.kazanci.com.tr/. Erişim tarihi: 03.03.2021). Bu hususta ayrıca bkz. Erdem, Mehmet: "Yasal Önalım Bedeli ve Yargıtay İçtihatları Çerçevesinde Bedelin Güncellenmesi Meselesi”, Prof. Dr. Haluk BURCUOĞLU’NA Armağan, C. I, Filiz Kitabevi, İstanbul, 2020, s. 798 vd. 
adına tescile karar verilmeden önce bu bedelin hâkim tarafından belirlenen süre içinde ve hâkimin belirleyeceği yere nakden yatırılması zorunludur.

$\mathrm{Bu}$ bağlamda, taşınmazın satış bedeli de, resmi senette gösterilen bedeldir. Satış bedeli resmi senetten açıkça görüleceği için, esasen bedelde muvazaa halleri dışında, kural olarak tartışmaya da mahal vermez. Bununla birlikte, paranın alım gücündeki değişikliklere bağlı olarak bu bedelin güncellenmesi ihtiyacı ortaya çıabilir.

Yargıtay'ın satı̧̧ bedelinin güncellenmesine ilişkin uygulaması zaman içinde değişiklik göstermiştir. Esasen bu konuyu mülga 743 sayılı Türk Medeni Kanunu ve mevcut 4721 sayılı Türk Medeni Kanunu çerçevesinde değerlendirmek gerekmektedir. Şöyle ki, mevcut Medeni Kanun önalım hakkının kullanımını süreyle sınırlandırmış olduğundan -önceki Medeni Kanun'a göre- daha kısa süre içinde önalım hakkı kullanılabilecektir (TMK m. 733/4). Hal böyle olunca da, güncelleme ihtiyacı görece daha az ortaya ç1kacaktır. Buna karşılık önceki Medeni Kanun zamanında açık kanun hükmüyle süre sınırlaması olmadığı için hakkın kullanımı satıştan çok sonra gerçekleşebilmekteydi ${ }^{87}$.

5 Mayıs 1993 tarihli Hukuk Genel Kurulu kararına ${ }^{88}$ konu olayda, 1982 ve 1983 'de iki paydaşın paylarını üçüncü bir kişiye satmaları, o sırada yurt dışında bulunan diğer paydaşın ise 1988 yılında yurda döndüğünde satışları öğrenip bir ay içinde hakkını kullanması söz konusu olmuştur. Davacı paydaş hakkını tapuda gösterilen bedel (90.100 TL.) üzerinden kullanmış, akabinde Sulh Hukuk Mahkemesi'nde dava açmış, ancak yapılan keşifte taşınmazın değerinin davanın açıldığı tarihte 44.000 .000 TL. olduğunun belirlenmesi üzerine mahkeme görevsizlik kararı vermiştir. Kararın temyiz edilmesi üzerine, Yargitay 2. Hukuk Dairesi bu kararı önalım bedelinde tapudaki değerin esas olduğu gerekçesiyle bozmuş, direnme üzerine konu Hukuk Genel Kurulu'nun önüne gelmiştir.

Hukuk Genel Kurulu, “... Yargitay uygulamasinda, (YHGK.'nun 7.10.1931 günlü kararından beri, bkz. Tepeci Notlu izahlı Türk Kanunu Medenisi II 1946, sh. 49) Şufa bedeli olarak ödenmesi gereken miktar "Davalıya tapuda yapılan satı̧sta düzenlenen sözleşme tablosunda (sicilde) gösterilenle" sinırlı olduğu kabul edilmekte idi. Ancak Şufa (önalım) bedeli ola-

87 Geniş bilgi için bkz. Şıpka, Şükran: "Yargıtay Kararları Doğrultusunda Taşınmazdaki Değer Artışlarının Kanuni Önalım (Şuf’a) Bedeline Yansıtılması”, İstanbul Üniversitesi Mukayeseli Hukuk Araştırmaları Dergisi, 1996, C. 20, s. 31 vd.; Erdem, s. 802 vd.

88 YHGK, 1993/6-761 E., 1993/192 K., 5.5.1993 T. (http://www.kazanci.com.tr/. Erişim tarihi: 19.10 .2020$)$. 
rak tapu sicilinde gösterilerinin esas alınmasl, hakkaniyet ile bağdaşmayan ve çıkarlar dengesini bozan durumlar meydana getirmektedir. Ülkemizde, genel olarak, taşınmaz satımlarında-tapuda-satış bedeli olarak gerçek değer yerine "emlak vergisine esas alınan daha düşük değer" gösterilmektedir. Diğer taraftan Şufa (önalım) hakkının kullanılması, satış işleminin ortaklara resmen duyurulmaması nedeniyle olayımızda olduğu gibi satıştan senelerce sonra gerçekleşebilmektedir. İşte, gerek gerçeği yansitmayan sicildeki düşük bedelin kabul edilmesi ve gerekse satış günü ile Şufa hakkının kullanıldiğı (genellikle tescil) davası ile birlikte kullanılmakta) gün arasında geçen sürede taşınmazın değerinde enflasyon ve diğer objektif nedenlerle meydana gelen artışların gözetilmemesi, hukukun amacı olan adaletin somutlaşmasını (hakkaniyet) önlediği ve çıkarlar dengesini bozduğu tartışılmayacak biçimde ortaya çıkmaktadır. Bu durumda Şufa (önalım) hakkı sahibi nedensiz zenginleşirken alıcı olan davall, fakirleşmektedir. Nitekim olayımızda, davalıya (tapu sicilindeki bilgiye göre) 1982 yllında 90.100.-

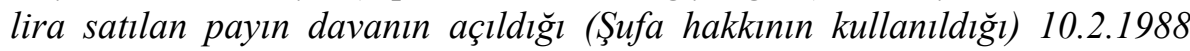
günündeki değerinin yaklaşık 30.000.000.- lira olduğu belirlenmiştir. Şufa bedeli olarak 30.000.000.- TL.ye karşılık 90.100.- liranın ödenmesini kabul etmenin hakkaniyete uygun düşeceğini savunma olanağ yoktur, konunun tartışılması sırasında bu durum oybirliği ile benimsenmiștir. Sorun, ç̈̈züm yolu ve yönteminde toplanmıștır..." ş̧eklinde sorunu ortaya koymuştur. Devamında “...Şufa (önalım) hakkının, kullanılması nedeniyle uygulamada ortaya çıkan ve tartışmasız kabul edilen adaletsiz (hakkaniyet) durumun yorum yoluyla düzeltilmesi olană̆ı olduğu kabul edilmelidir. Unutulmamalıdır ki, yasaların uygulanması sırasinda görülecek haksıllkların, adaletten sapmaların düzeltilmesi ilk önce yargıya düşen bir görevdir. Yasa'nın açık ve buyurucu bir emri olmadıkça yargı bu görevini yerine getirmekle yükümlüdür. Olayımızda yasal bir değişikliğe ve düzenlemeye gerek bulunmadığına göre bindokuzyüzotuzlardan günümüze kadar gelen yerleşmiş inançtan dönülerek, önalım (Şufa) bedelinin payın satışında tapu sicilinde gösterilen

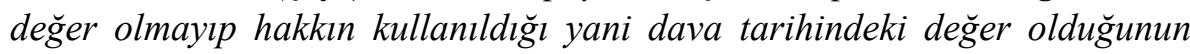
kabulü hukukun temel amaçlarından olan adaleti (hakkaniyet) gerçekleştirecektir..." denilmiştir. Sonuç itibariyle de, oy çokluğu ile temyiz itirazlarını reddedip direnme kararını onamıştır ${ }^{89}$.

89743 sayılı Türk Medeni Kanunu'nun uygulandığı dönemde verilen bu yöndeki başkaca kararlar için bkz. YHGK 1996/6-61 E., 1996/164 K., 13.3.1996 T.; YHGK 1994/6-663 E., 1994/841 K., 14.12.1994 T.; YHGK 2012/6-1127 E., 2013/434 K., 3.4.2013 T. (http://www.kazanci.com.tr/. Erişim tarihi: 19.10.2020). Ayrıca bkz. Erdem, s. 807 vd. ve dipnot 41 vd.'nda yollama yapılan kararlar. 
4721 sayılı Medeni Kanun'un yürürlüğüne kadar verilen kararlarda, payın satışı ile önalım hakkının kullanıldığı zaman arasında uzunca bir süre geçmiş olması halinde, önalım bedelinin payın önalım hakkının kullanıldığ 1 tarihteki değerine, daha önce kullanılmamış olması halinde dava tarihindeki değerine göre belirlenmesi söz konusu olmuştur. Öte yandan, bu dönemde payın satışı ile önalım hakkının kullanıldığı veya dava açıldığı tarih arasında uzun bir zaman geçmemişse, önalım bedeli satış sözleşmesinde gösterilen bedele göre belirlenmiştir ${ }^{90}$.

4721 sayılı Türk Medeni Kanunu, önalım hakkının kullanılabilmesi için paydaşlara bildirim yükümlülüğü getirdiği gibi (TMK m. 733/3), önalım hakkının kullanımını da süreyle sınırlandırmıştır. Hal böyle olunca, çok uzun süre sonra (TMK m. 733/4 gereği en çok iki yıl) önalım hakkı kullanılması ihtimali bertaraf edilmiş olmaktadır. Hakkın geç kullanımı, kural olarak, bildirim yükümlülügün yerine getirilmemiş olmasından ileri geleceği için, sonuçlarına da önalım hakkı sahibi paydaşın değil alıcının katlanması gerekecektir. Nitekim Yargıtay'ın uygulaması da bu yöndedir ${ }^{91}$.

Öte yandan, her ne kadar mevcut Medeni Kanun bağlamında hakkın kullanımı en çok satıştan iki sene sonra gerçekleşebilecek olsa da, sürenin uzaması taşınmaz satış vaadi sözleşmesi sebebiyle de söz konusu olabilir. Şöyle ki, paydaş ile alıcı arasında bir taşınmaz satış vaadi sözleşmesi olup da, paydaşın satış sözleşmesi yapmaması üzerine vaad alacaklısı cebri tescil davası açmış olabilir. Mahkemenin devir kararı vermesi halinde diğer paydaşlar için önalım hakkı doğacaktır. Ancak bu ihtimalde devrin sağlanması uzun bir mahkeme sürecinden sonra gerçekleşebilir. Bu halde de bedelin güncellenmesi ihtiyacı hâsıl olabilir. Bu husus Yargıtay kararlarına da konu olmuştur. Yargıtay, bu hallerde davanın kabulünü kural olarak payın dava tarihine göre belirlenen değerinin davacıdan alınması koşuluna bağlamaktadır ${ }^{92} 93$. Bundan başka, bu konu Anayasa Mahkemesi'ne bireysel başvu-

90 Erdem, s. 813 vd. Uzun zamanın ne kadarlık bir süreye tekabül ettiği açık değildir ancak Yargıtay kararlarına baktığımızda bir yıla kadar olan süreleri uzun kabul etmediği görülmektedir. Bkz. YHGK 2001/6-299 E., 2001/295 K., 28.3.2001 T.; 6. HD 2004/175 E., 2004/254 K., 26.1.2004 T.; 6. HD 2002/3186 E., 2002/4285 K., 25.06.2002 T. (http://www.kazanci.com.tr/. Erişim tarihi: 19.10.2020).

91 YHGK 2009/6-31 E., 2009/68 K., 11.2.2009 T.; YHGK 2009/6-32 E., 2009/68 K., 11.2.2009 T. (http://www.kazanci.com.tr/. Erişim tarihi: 19.10.2020). 6. HD, 11109/ 13508, 2.12.2008 T.; 6. HD 2017/4445, 16.04.2007 T., Tunaboylu, s. 412-413; s. 416417; Erdem, s. 814-815.

92 YHGK 6-663/841, 14.12.1994 T.; YHGK 6-673/898, 28.12.1994 T., Tunaboylu, s. 430-432, s. 432-434; 6. HD, 2012/16738 E., 2013/10770 K., 20.06.2013 T. 
ruya ve Anayasa Mahkemesi kararına da konu olmuştur. Anayasa Mahkemesi önalım davacısının ödemesi gereken bedelin enflasyon farkına göre güncellenmesi gerektiğine, bu yapılmadığı için mülkiyet hakkının ihlal edildiğine ve başvurucuya tazminat ödenmesine hükmetmiştir ${ }^{94}$.

\section{B. Satış Bedelinde Muvazaa Halleri}

\section{Genel Olarak Bedel Muvazaası}

Yukarıda da ifade ettiğimiz üzere, muvazaa anlaşması görünürdeki işlemin tamamına ilişkin olabileceği gibi, bir kısmına ilişkin de olabilir. İlkinde tam muvazaa, ikincisinde ise kısmi muvazaa söz konusu olur. Tarafların yaptıkları satış sözleşmesinde satış bedelini gerçek satış bedelinden daha düşük veya daha yüksek göstermeleri halinde kısmi muvazaa mevcuttur. Kısmi muvazaa şeklinde ortaya çıkan bu muvazaaya spesifik olarak bedel muvazaası denir ${ }^{95}$. Öte yandan buradaki muvazaa nisbi muvazaadır. Dolayısıyla ve esas itibariyle gizli işlemde şekle aykırılık söz konusudur ve kural olarak yaptırım da kesin hükümsüzlüktür. Satış bedeli sözleşmenin esaslı noktasıdır ve sözleşmede gösterilen bedel, gerçek bedelden farklıdır. $\mathrm{Bu}$ nedenle, kural olarak, görünürdeki işlem muvazaa sebebiyle, gizli işlem şekle aykırılık sebebiyle geçersizdir ${ }^{96}$. Bedel muvazaası yapılmış sözleşmeye

(http:/www.kazanci.com.tr/. Erişim tarihi: 19.10.2020); 6. HD, 12623/13393, 13.12.2011 T., Günay, s. 276-277; Erdem, s. 818 vd.

93 Önalım bedelinin güncellenmesi gereken hallerde, güncellemenin nasıl ve özellikle hangi tarihe (dava tarihi - depo kararının verildiği tarih) göre yapılacağı hususunda geniş bilgi ve Yargitay uygulaması için bkz. Erdem, s. 829-832.

94 Bkz. Başvuru No: 2016/77854, 1.7.2020 T.; Başvuru No: 2017/15134, 29.1.2020 T. (https://kararlarbilgibankasi.anayasa.gov.tr/BB/2016/77854 Erişim tarihi: 24.03.2021).

95 Esener, s. 62 vd.; Aday, s. 54 vd.; Atamulu, s. 225 vd. Bu hususta ayrıca bkz. ve karş. Cihan, Ali Hulki: "Taşınmaz Devirlerinde Bedelde Muvazaanın Sözleşmeye Etkisi”, Akdeniz Üniversitesi Hukuk Fakültesi Dergisi, Aralık 2013, S. 2, s. 105.

96 Esener, s. 63-64; Tandoğan, Haluk: Borçlar Hukuku Özel Borç İlişkileri C. I/1, 6. Basım, Vedat Kitapçılık, İstanbul, 2008, s. 237; Sirmen, Lale: "Taşınmaz Satımlarında Bedelin Düşük Gösterilmesinin Hukuki Sonuçları” (Bedel), Prof. Dr. Jale G. AKİPEK'E Armağan, Selçuk Üniversitesi Hukuk Fakültesi, Konya, 1991, s. 305 vd., s. 311; Aday, s. 55-57; Atamulu, s. 230; Kocayusufpaşaoğlu/Hatemi/Serozan/Arpacı, s. 357-358 Karş, Eren, s. 403; Tekinay, Selahattin Sulhi/Akman, Sermet/Burcuoğlu, Haluk/ Altop, Atilla: TEKİNAY Eşya Hukuku, 5. Bası, Filiz Kitabevi, C. 1, İstanbul, 1989 (TEKINAY Eşya), s. 669-670. Bu görüş Federal Mahkeme kararlarında da kabul görmüştür. Ancak tarafların edimlerini ifa ettikten sonra muvazaa iddiasında bulunmaları hali hakkın kötüye kullanımı teşkil ettiği için, işlem geçerliymiş gibi sonuç doğurmaktadır. Bkz. Gauch, Peter/Schluep, Walter R./Schmid, Jörg/Emmenegger, Susan: Schweizerisches Obligationenrecht Allgemeiner Teil, Band I, Zürich, 2008, s. 223, N. 1035; Wiegand, Bas.Kom, OR I, Art. 18, s. 160, N. 52. Karş. Kramer, Ber.Kom., Art. 
istinat eden tescil de, kural olarak yolsuz tescildir. Bu bağlamda tescilin yolsuzluğunun düzeltilebilmesi için tapu sicilinin düzeltilmesi davası açılabilir, keza taraflar yaptıkları işlemlere istinaden birbirlerine vermiş olduklarını sebepsiz zenginleşme ve istihkak davasıyla talep edebilirler. Bununla birlikte, şekle aykırılığ 1 ileri sürmenin hakkın kötüye kullanımı teşkil ettiği hallerde, geçersiz işlem, geçerliymiş gibi hüküm ve sonuç doğuracaktır ${ }^{97} 98$.

Esasen bedel muvazaası sebebiyle tarafların birbirlerine karşı muvazaa iddiasında bulunması pratikte gerçekleşmesi zor bir ihtimaldir. Zira taraflar zaten işlemi yapmak istemekte; fakat çeşitli sebeplerden -esaslı nokta olmakla birlikte- bedeli gerçekten farklı göstermektedirler ${ }^{99}$. Bir başka ifadeyle, taşınmazı satanın ve alanın yapmak istediği zaten budur, tam muvazaada olduğu gibi satış gösterip bağış yapmak istemek veya tam tersi söz konusu değildir. Öte yandan, muvazaalı işlemi yapan taraflar, çok defa edim borçlarını da yerine getirmiş olacaklardır. Hal böyle olunca muvazaa iddiasının hakkın kötüye kullanımı teşkil etmesi kuvvetle muhtemeldir. Keza tarafların birbirine karșı muvazaayı ispatlamaları da yazılı delil gerektirecektir (HMK m. 200-201) ${ }^{100}$.

Bununla beraber, belirtmek gerekir ki, Yargıtay'ın hakkın kötüye kullanımı hususunu tartışma konusu yapmadan bedel muvazaası yapılmış devri geçerli saydığ kararları da mevcuttur. Hukuk Genel Kurulu 29.2.2012 tarihli kararında şu ifadelere yer vermiştir: “... Tarafların protokolde bedeli 250.000 $T L$, tapu satış senedinde ise 93.000 TL olarak göstermeleri bilindiği üzere az vergi ödemek amacıyla yapılan bir işlem olup taraflar arasındaki sözleşmenin gecersiz olmasına sebep olmavacaktır. Taraflar görünüşteki sözleş-

18, N. 194 vd. Federal Mahkeme kararları için bkz. BGE 78 II 224; BGE 84 IV 163164; BGE 104 II 101.

97 Atamulu, s. 231.

98 Türk hukukunda vergi mevzuatına istinaden yapılan işlemi geçerli kabul eden görüşe ilișkin geniş bilgi için bkz. Aday, s. 54 vd.; Atamulu, s. 237 vd. Tarafların edimlerini ifa etmiş olması halinde geçersizliği ileri sürmesinin hakkın kötüye kullanımı teşkil edeceğine ilişkin bkz. YHGK, 1997/15-146 E., 1997/372 K., 30.4.1997 T.; 15. HD, 2002/2457 E., 2002/4795 K., 23.10.2002 T. (http://www.kazanci.com.tr/. Erişim tarihi: 15.03.2021).

99 Esas itibariyle, bedel esaslı nokta olduğu için bu işlemin hükümsüz olduğu gerçeğini değiştirmemektedir.

100 Atamulu, s. 205. Bkz. YHGK 2003/1-374 E., 2003/370 K., 28.05.2003 T. (http://www.kazanci.com.tr/. Erişim tarihi: 15.03.2021). Hemen belirtelim ki, yazılı delil dışındaki diğer kesin delillerle de ispat mümkündür. Bkz. 1. HD, 2013/8612 E., 2013/12448 K., 12.9.2013 T(http://www.kazanci.com.tr/. Erişim tarihi: 15.10.2021). Ayrica bkz. 3. HD, 2014/413 E., 2014/7545 K., 15.5.2014 T. (http://www.kazanci. com.tr/. Erişim tarihi: 15.10.2021). 
meyi yapmay ciddi olarak istemekte ve niteliğinde de anlaşmaktadırlar. Sadece sözlessmenin bedeli değiștirilmektedir. Burada muvazaa sözleşmenin tamamında değil bir bölümünde gerçekleşmiştir...”. Yargıtay şekle aykırılık, şekle aykırılığın kesin hükümsüzlük sonucu doğurması meselelerine hiç değinmeksizin, sözleşme bedeli esaslı nokta değilmiş gibi, (taraflar) sadece bedeli değiştirmişler demektedir ${ }^{101}$. Ancak bu yönde karar verdiği çekişmelerde, edimlerin tamamıla yerine getirilmemiş olduğu iddiaları söz konusudur $^{102}$. Bedel gerçekten farklı gösterilse bile, her iki tarafın da edimi tamamen ifa ettikleri halde, kuvvetle muhtemeldir ki, tarafların bu sebeple mahkemenin önüne götürecekleri bir çekişme de söz konusu olmayacaktır.

Yargıtay'ın bu tavrı, satış bedelinde muvazaanın yaygın olmasından ve bu türden satış sözleşmelerinin tümünün kesin hükümsüzlük yaptırımına tabi tutulması halinde deyim yerindeyse işin içinden çıkılamayacağ ileri geliyor olmalıdır ${ }^{103}$. Bununla birlikte, bu kayg1, uygulamay1, gizli bedel anlaşmasını ne pahasına olursan olsun ayakta tutmak için Borçlar Kanunu'nun genel sistematiğinden uzaklaşan gerekçeler üreterek çözmek yoluna götürmemelidir. Olması gereken bu sorunu hakkın kötüye kullanımı yasağı bağlamında çözmektir ${ }^{104}$.

Üçüncü kişilerin yani sözleşme tarafları dışındakilerin -konumuz bağlamında önalım hakkı sahibi paydaşların- muvazaayı her türlü delille ispatlamaları mümkündür (HMK m. 203/1 b. d). Önalım hakk1 söz konusu olduğunda, muvazaa iddiası çok defa önalım hakkı sahibi paydaşlardan gelmektedir ve tapuda gösterilen bedelin gerçek bedelden yüksek olduğu şeklinde ortaya çıkmaktadır. Müteakip bölümde bu husustaki uygulamayı değerlendireceğiz.

\section{Satış Bedelinin Tapuda Yüksek Gösterilmesi Halinde Gerçek Bedel Üzerinden Kullanılması}

Satış bedelinin önalım hakkı kullanımını engellemek amacıyla gerçek bedelden yüksek gösterilmesi halinde, önalım hakkı sahibinin muvazaa

101 YHGK 2011/13-716 E.; 2012/106 K.; 29.2.2012 T. (http://www.kazanci.com.tr/. Erişim tarihi: 29.04.2021).

102 1. HD, 2013/18950 E.; 2014/6764 K.; 31.3.2014 T. Ayrıca bkz. otomobil satıșına ilișkin olmakla beraber aynı yönde YHGK 2011/19-841 E.; 2012/144 K.; 14.3.2012 T. (http://www.kazanci.com.tr/. Erişim tarihi: 29.04.2021).

103 Özbilen, s. 262, dipnot 806.

104 Bu yönde bkz. Özbilen, s. 265-266. Bedelde muvazaada kısmî hükümsüzlük yaptırımının uygulanması yönünde bkz. Şenol, Nilay: "Taşınmaz Satı̧̧ Sözleşmelerinde Bedelde Muvazaa ve Sonuçları", YÜHFD, C. XV, 2020/1, s. 333 vd. 
iddiasında bulunup gerçek bedeli ispat edip gerçek bedel üzerinden önalım hakkını kullanması mümkündür. Esasen önalım hakkına ilişkin uygulamada en çok görülen hal de budur. Önalım hakkı sahibi taraflara nazaran üçüncü kişi olduğu için ispat için kesin delil göstermesine de gerek yoktur, her türlü delille ispat faaliyetini gerçekleştirebilecektir. Nitekim Yargitay bu halde, bedelde muvazaa iddiasında bulunan davacının, satış sözleşmesinin tarafı olmadığından, iddiasını tanık dâhil her türlü delille kanıtlamasının mümkün olduğunu kabul etmektedir ${ }^{105}$.

Bundan başka, yine Yargıtay kararlarıyla ortaya konulan bir diğer husus, muvazaa iddiasında bulunulması halinde, başkaca hiçbir delil göstermeden sadece keşif ve keşifle ortaya konan bedelin satış bedelinden düşük olması halinin muvazaayı ispata yetmeyeceğidir ${ }^{106}$.

105 “...Uyuşmazlık, önalım hakkına konu edilen payın iptali ve davacı adına tesciline ilişkindir... Önalım hakkının kullanılması ile bu hakkı kullanan paydaş ile alıcı arasında kapsam ve şartları satıcı ile davalı arasında yapılan sözleşmenin aynı olan bir satım ilişkisi kurulmuş olur. Önalım hakkını kullanan paydaş bu payı satın almak isterken tapuda gösterilen satış bedeli ile davalt tarafından ödenen harç ve masraflar toplamından ibaret önalım bedelini depo etmesi gerekir. Ancak davacı tapuda yapılan satış sözleşmesinin tarafi olmadığından bedelde muvazaa iddiasında bulunabilir ve bu iddiasını her türlü delille kanitlayabilir... Davacı bedelde muvazaa iddiasında bulunduğuna göre bu iddiasını kanıtlaması gerekir. Satıs sözlesmesinin tarafı olmadığından bu iddianın tank dâhil her türlü delille kanıtlanması mümkündür. Davact vekili de bu konuda 19.10.2009 tarihli dilekçesi ile delillerini bildirmiştir. Ancak mahkemece bedelde muvazaa iddiası konusunda tarafların göstermiş olduğu delilleri toplamadan, yerinde keșif ve bilirkişi incelemesi yaptırmadan tapuda gösterilen bedel üzerinden önalım bedelinin süresinde yatırılmadiğından söz ederek davanın reddine karar vermiştir. Bedelde muvazaa iddiasıyla açılan davalarda depo ettirilecek bedel, bu iddia doğrultusunda tarafların delillerinin toplanmasindan sonra belirlenebilir...”, 6. HD, 81/ 2192; 01.03.2011 T., Tunaboylu, s. 357-358. Bu yönde ayrıca bkz. 6440/6704, 21.10.2002 T., Tunaboylu, s. 367-368.

106 “...Kabule göre de, dava konusu 1/2 payın mülkiyetinin naklini sağlayan resmi senet içeriğinden bu payın davalıya 110.000,00TL bedelle satıldı ̆̆ anlaşılmaktadır. Davacı vekili, dava dilekçesinde miktar belirtmeksizin gerçek satış bedelinin daha düşük olduğunu, önalım hakkına engel olmak için bedelin muvazaalı olarak yüksek gösterildiğini iddia ederek keșif ve bilirkisi incelemesi delillerine dayanmış; mahallinde yapılan keşif sonrası sunulan bilirkişi raporunda da dava konusu taşınmazın devir tarihi itibariyle toplam değerinin 135.335,00TL olduğu bildirilmiştir. Mahkemece, her ne kadar taşınmazın bilirkişi tarafindan belirlenen toplam değerinden dava konusu 1/2 paya isabet eden 67.667,50TL üzerinden davanın kabulüne karar verilmiş ise de keşfen belirlenen bu bedel davacının bedelde muvazaa iddiasını kanttamaya yeterli değildir... $O$ halde mahkemece, davacı taraf bedelde muvazaa iddiasını kanitlayamadı̆̆ından, 4721 Sayılı TMK'nın 734. maddesi uyarınca tapuda gösterilen satış bedeli ile davalı tarafindan ödenen harç ve masrafların toplamindan ibaret olan önalım bedelini depo 
Önalım hakkı sahibinin muvazaa iddiasında bulunması ve bunu ispat etmesi halinde, gerçek bedel üzerinden önalım hakkını kullanması mümkün olacaktır. Bu durumda mahkeme gerçek bedelin üzerine alıcı - davalının harç ve masraflarını ekleyip bu değer üzerinden depo kararı verecektir ${ }^{107}$.

\section{Satış Bedelinin Tapuda Düşük Gösterilmesi Halinde Düşük Gösterilen Bedel Üzerinden Kullanılması}

\section{a. Genel Olarak}

Tarafların satış bedelini düşük gösterdikleri fakat edimlerini tamamen yerine getirdikleri halde, bu sözleşmenin mahkeme önüne gelmesi esasen önalım hakkı sahibinin hakkını kullanmasıyla olacaktır. Nitekim yukarıda da ifade ettiğimiz üzere ${ }^{108}$ bedelin düşük gösterilmesi halinde çekişmenin mahkemenin önüne gelmesi, edimlerin, özellikle tarafların kendi aralarında

etmek üzere davacıya süre verilerek sonucuna göre bir hüküm kurulması gerekirken, dava konusu payın keşfen belirlenen değeri üzerinden davanın kabulüne karar verilmesi de doğru görülmemiş, açılanan nedenlerle hükmün bozulması gerekmiştir... ”, 14. HD, 2016/16022 E., 2020/3403 K., 04.06.2020 T., Ruhi/Ruhi, s. 277-279. Keza ayn1 yönde bkz. “...Davacılar vekili bedelde muvazaa iddiasında bulunmuş, bedelde muvazaa iddiasında bulunan davacının muvazaayı her türlü delil ile kanıtlama imkânı bulunmasına karşın; dosya kapsamı içerisinde davacıların muvazaa iddiası yeterli delillerle kanıtlanamamıştır. Dairemizin 24.02.2015 tarihli bozma ilamında bu husus belirtilmiş olmasına ve mahkemece de bozma ilamina uyulmasına karar verildiği halde bozma gereği yerine getirilmeyerek bedelde muvazaa iddiasının kabulüyle keşifte belirlenen değer ve tapu masrafları toplamı olarak depo edilen 82.587,50 TL miktarın davalıya ödenmesine karar verilmesi doğru değildir... Mahkemece, davacılar bedelde muvazaa iddiasın kanıtlayamadıklarından, 4721 Sayılı TMK'nın 734. maddesi uyarınca tapuda gösterilen satış bedeli ile davalı tarafindan ödenen harç ve masrafların toplamından ibaret olan önalım bedelini depo etmek üzere davacılara süre verilerek sonucuna göre bir hüküm kurulması gerekirken, dava konusu payın keşfen belirlenen değeri üzerinden davanın kabulüne karar verilmesi doğru görülmemiş, hükmün bu nedenle bozulması gerekmiştir...”14. HD, 2019/2583 E., 2020/2998 K., 11.03.2020 T., Ruhi/Ruhi, s. 294-296. “... Kabule göre de, bedelde muvazaa iddiasının salt kessifte belirlenen miktar ile kanitlanamavacağı, tanık bevanlarının da görgüve ve bilgive davalı olması gerektiği hususunun gözetilmemesi de doğru görülmemiştir...”, 14. HD, 2016/15549 E., 2020/3386 K., 04.06.2020 T., Ruhi/Ruhi, s. 281-283.

107 “... Bedelde muvazaa iddiast ile açılan davalarda depo ettirilecek bedel, bu iddia doğrultusunda tarafların delillerinin toplanmasından sonra belirlenebilir. Bu itibarla öncelikle bedelde muvazaa konusunda tarafların göstermiş olduğu delillerinin toplanmasl, tüm deliller birlikte değerlendirildikten sonra varılacak sonuç itibariyle davacıya onalım bedelini depo etmesi için uygun süre tanınması ve sonucuna göre bir karar verilmesi gerekirken yazılı şekilde hüküm kurulması doğru görülmediğinden kararın bozulması gerekmiştir...” Bkz. 6. HD, 81/2192, 01.03.2011 T., Tunaboylu, s. 357-358.

108 Bkz. Yukarıda II, B, 1. 
kararlaştırdıkları gerçek bedelin tamamen ifa edilmemiş olması halinde söz konusu olmaktadır. Onun dışında düşük bedel iddiasının mahkemenin önüne gelmesi ise, önalım hakkı sahibinin hakkını kullanmak için dava açmasıyla gerçekleşecektir.

Bedel muvazaasının en çok görülen türü, tapu kütüğünde satış bedelinin, gerçek satış bedelinden düşük gösterilmesidir. Fakat bu muvazaada amaç esas itibariyle "ilgili üçüncü kişileri" aldatmak değil, deyim yerindeyse Vergi İdaresini aldatmak, ödenmesi gereken vergi ve harc1 az ödemektir ${ }^{109}$. Yargıtay, daha önce de ifade ettiğimiz üzere, bedel muvazaası yapılmış bu türden hukuki işlemleri geçerli kabul etmekte, sadece tarafların vergi hukuku bakımından sorumluluklarının doğacağına işaret etmektedir. Şöyle ki; “...Taraflarin protokolde bedeli $250.000 \mathrm{TL}$, tapu satıs senedinde ise 93.000 TL olarak göstermeleri bilindiği üzere az vergi ödemek amacıyla yapılan bir işlem olup taraflar arasındaki sözleşmenin gecersiz olmasına sebep olmayacaktır. Taraflar görünüssteki sözleşmeyi yapmayı ciddi olarak istemekte ve niteliğinde de anlaşmaktadırlar. Sadece sözleșmenin bedeli değiștirilmektedir. Burada muvazaa sözleşmenin tamaminda değil bir bölümünde gerçekleşmiş̧tir... Satış bedelinin 93.000 TL olarak gösterilmesinin sadece verginin düşük gösterilmesi amacını taşıyan bir işlem olarak varsayılması, bu durumunda da yani düşük vergi gösterilmiş olması hususunun da resen hareket edilerek ilgili vergi dairesine ihbar edilmesi gereklidir... ${ }^{110 " ~ i f a d e s i ~}$ bu hususu açıkça göstermektedir.

\section{b. Yargitay Uygulamast}

Yargıtay, tarafların düşük harç ve vergi ödemek için satış bedelini gerçekten düşük gösterdikleri hallerde, önalım hakkı sahibinin önalım hakkını bu düşük gösterilen bedel üzerinden kullanacağını büyük ölçüde kabul etmektedir. Esasen bu hususta nispeten istikrar kazanmış uygulaması, davalı alıcının davacı önalım hakkı sahibine karşı kendi muvazaasına dayanamayacağı, bunun hakkın kötüye kullanımı teşkil edeceği yönündedir.

Yargıtay, bir kararında, davacı alıcının, daha önce aynı taşınmazın 1/3 payını, önalım hakkı kullanmak istediği pay için tapuda öngörülen bedelden çok daha yüksek bir bedele satın almış ve fakat düşük bedel üzerinden önalım hakkı kullanmış olmasını uygun bulmuştur. Burada davalının, davacı

109 Bu hususta ayrıntılı bilgi için bkz. Şenol, s. $316 \mathrm{vd.}$

110 YHGK 2011/13-716 E.; 2012/106 K.; 29.2.2012 T. (http://www.kazanci.com.tr/. Erişim tarihi: 29.04.2021). 
önalım hakkı sahibinin hakkını kötüye kullandığı iddiası Hukuk Genel Kurulu tarafindan kabul görmemiştir ${ }^{111}$.

Yargıtay'ın bir diğer kararında ise şu ifadeler yer almaktadır: “...Hukuk Genel Kurulu önüne gelen uyuşmazlık, önalım bedelinin belirlenmesinde tapudaki satış bedelinin mi yoksa temlik tarihi itibariyle hesaplanan (davalının ödediğini iddia ettiği) gerçek bedelin mi esas alınması gerektiği noktasinda toplanmakta olup; Kurulda yapılan görüşmeler sonunda çoğunlukça, dosya içeriği ve toplanan deliller uyarınca TMK'nın 734. maddesinde düzenlendiğ $i$ ve Özel Daire bozma kararında belirtildiği gibi önalım bedelinin belirlenmesinde esas alınacak satış bedelinin tapudaki satış bedeli olarak anlaşılması gerektiği kanaatine varılmıştır. Hukuk Genel Kurulu görüşmeleri sırasında bir kısım üyelerce, paylı mülkiyete tabi taşınmazda pay satın

111 “... Direnme yoluyla Hukuk Genel Kurulu önüne gelen uyuşmazlık; dava konusu taşınmazda 1/3 payı 14.01.2008 tarihinde tapuda 90.000,00TL satış bedeli göstererek satın alan davacının, aynı taşınmazda 1/3 payı 11.05.2011 tarihinde 27.000,00TL satış bedeli göstererek davalının satın alması durumunda davacının tapuda gösterilen 27.000,00TL satıs bedeli üzerinden sufa hakkı kullanmak istemesinin hakkın kötüye kullanılması olarak değerlendirilip değerlendirilemeveceği, davalının bedelde muvazaa iddiasının dinlenip dinlenemeyeceği noktasında toplanmaktadır... Taraflar tapuda yapılan tescil işlemi ile sözleşmeyi ifa ettiklerine ve bu sözleşmenin koşulların yerine getirip ana unsurlarını gerçekleştirdiklerine göre bedelde muvazaa iddiasını ileri sürerek sözleşmenin iptalini istemeleri "hakkın kötüye kullanılması" olarak değerlendirilmektedir (Eraslan Özkaya, İnançl işlem ve Muvazaa Davaları, Ankara, Mayıs 2015, sayfa 187)... Diğer taraftan șufa hakkını kullanan paydașa karș satıs bedelinde muvazaa bulunduğu, gerçekte bedelin daha fazla olduğu, sözleșmenin taraflarından biri (alıcı) tarafindan ileri sürülmesi de hakkın kötüye kullanılması teşkil eder (Eraslan Özkaya, Inançl işlem ve Muvazaa Davalarl, Ankara, Mayıs 2015, sayfa 197). Somut olaya gelince; davacı, dava konusu 1393 ada 1 parsel sayılı taşınmazda paydaş olduğunu, dava dışı İ. 11.05.2011 tarihinde dava konusu taşınmazdaki 1/3 payını davalıya 27.000,00 TL bedelle sattığını, tapudaki satış bedeli üzerinden önalım hakkın kullanmak istediğini belirterek davalı adına kayıtlı 1/3 payın iptali ile adına tescilini istemistir. Davalı ise dava konusu payı gerçekte 93.000,00TL bedelle satın aldığını ancak tapuda satış bedelinin 27.000,00TL olarak gösterildiğini sonradan öğrendiğini, şufa hakkının ancak gerçek bedel üzerinden kullanlabileceğini ileri sürerek davanın reddini savunmuştur. Davalı, dava konusu taşınmazdaki 1/3 payın satışına ilişkin 11.05.2011 tarih 7471 yevmiye numaralı satış akdinin tarafi olduğundan ve hiç kimse kendi muvazaasına dayanamayacağından davalının bedelde muvazaa iddiasında bulunması açıkça hakkın kötüye kullanmasıdır. Bu itibarla, mahkemece dava konusu payın tapudaki satıs bedeli olan 27.000,00 TL ile tapu harc ve masraflardan olușan önalım bedelini depo etmek üzere davacıya uygun bir önel verilerek olușacak sonuca göre ișin esası hakkında bir karar verilmesi gerekirken bu husus gözetilmeksizin yazılı gerekçe ile davanın reddine karar verilmesi doğru değildir. Hal böyle olunca, Hukuk Genel Kurulunca da benimsenen Özel Daire bozma kararına uyulmak gerekirken, önceki kararda direnilmesi usul ve yasaya aykırldır. Bu nedenle direnme kararı bozulmalıdır...”, YHGK 2014/14-292 E., 2015/1544 K., 10.6.2015 T. (http://www.kazanci.com.tr/. Erişim tarihi: 02.10.2020). 
alan davalının, davaya konu payı tapuda gösterilen 5.000-TL bedelle değil, 200.000-TL bedelle satın aldiğını savunarak buna dair belge sunduğu ve tanık dinlettiği; burada bedelde muvazaa iddiasının isslemin tarafına değil üçüncü kisi olan davacıva karsı ileri sürülldüğü, bu iddianın her türlü delille kanıtlanabileceği, uyusmazlığın çözümünde 5.5.1993 tarih, 1992/6761 E., 1993/192 K. sayll Hukuk Genel Kurulu ${ }^{12}$ kararının dikkate alınmasl gerektiği, bu sebeple Yerel Mahkeme kararının yerinde olduğu görüşü ileri sürülmüs ise de, Kurul çoğunluğunca yukarda ve bozma ilaminda belirtilen sebeplerle bu görüs benimsenmemiștir... ${ }^{113 " .}$

Yollama yapılan kararda, azınlıkta kalan üyelerin istinat ettiği karar, yukarıda "Satış Bedelinin Değer Artışlarına Göre Mahkeme Tarafından Yeniden Belirlenmesi" başlığı altında yer verdiğimiz kararlardan biridir. Söz konusu kararda pratikte satış bedelinin düşük gösterilmesi meselesine de değinilmiştir ama esas mesele önalım hakkının geç kullanılması (mülga MK zamanında bu mümkündü) sebebiyle bu süre içinde ortaya çıkan değer artışının dikkate alınıp alınmayacağı meselesidir. Dahası kararın doğrudan konusu da mahkemenin görevi hususudur. Bu kararda, her ne kadar gerekçede düşük bedelden gösterme, muvazaanın ileri sürülüp sürülemeyeceği hususundaki görüşlere yer verilmişse de, nihayetinde taşınmazın değerinin zamanın geçmesine bağlı olarak ortaya çıkan değer artışına göre yeniden belirlenmesi ve bu değerleme üzerinden önalım hakkının kullanılması gerektiğine karar verilmesi söz konusudur. Bir başka ifadeyle, Yargıtay, bu kararda tapuda gösterilen düşük bedel üzerinden önalım hakkını kullanmak istemenin, önalım hakkı sahibinin hakkını kötüye kullanması anlamına geldiğine karar vermemiştir. Öte yandan karar oy çokluğuyla çıkmıştır.

Belirtmek gerekir ki, her ne kadar Yargitay tapuda gösterilen düşük bedel üzerinden hakkın kullanılacağını kabul ediyorsa da, bu sonucu bertaraf eden kararlar da vermiştir. Yargitay 14. Hukuk Dairesi 7.9.2020 tarihli kararında alıcının, önalım hakkı sahibi tarafından kendisine dava açılmadan önce, kütükte gösterilen düşük bedeli harç tamamlatmak suretiyle "düzeltmesi" halinde, önalım hakkı sahibinin artık bu düzeltilmiş bedel üzerinden önalım hakkını kullanılabileceğini kabul etmiştir. Davacı önalım hakkı sahi-

112 Bu karar için bkz. Yukarıda II, A.

113 YHGK 2014/356 E., 2016/491 K., 6.4.2016 T. (http://www.kazanci.com.tr/. Erişim tarihi: 02.10.2020). 2014/14-292 E., 2015/1544 K., 10.06.2015 T., Ruhi/Ruhi, s. 1150 1154. Yargitay'ın daha önceki tarihli kararları da bu yöndedir. 6. HD, 4143/4520, 19.04.1994 T.; 6. HD, 3010/4013, 28.03.1985 T.; 6. HD, 2428/2552, 17.03.1983 T., 391-392; 6. HD, 10412/10532, 16.11.1982 T. (Sirasiyla Tunaboylu, s. 381-382; 389$390 ; 391-392 ; 393-394)$. 
binin kütükteki bedel üzerinden hakkını kullanmak istemesini ise dürüstlük kuralı ile bağdaşmayacağ gerekçesiyle reddetmiştir $^{114}$.

Buna karşıllk, eski tarihli olmakla birlikte, bir başka kararında ${ }^{115}$, “... Dava konusu pay bidayette otuz bir lira bedelle satılmıştır. Davalı bu akdin

114 “...resmi satış sözleşmesine göre, davalı dava konusu taşınmazlardaki payları 24.11.2015 tarihinde toplam 9.240,00TL'ye satın almış; davalı tarafindan dosyaya ibraz edilen Gelendost Vergi Dairesinin 25.11.2015 tarihli, Afşar 2347, 7149 ve 7150 parseller için ek harç açılklamalı, 1.950,00TL miktarlı vergi dairesi alındısına göre, davalının

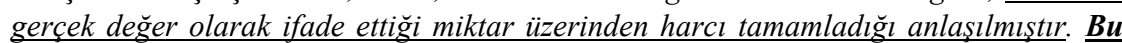
düzeltme ișlemi, önalım davasının açıldı̆̆ 04.12.2015 tarihinden önce tamamlanmıștır. Davalı taraf, satıs sözleșmesinde yer alan ve satış bedelinden kaynaklanan hatayı dava açılmadan önce yetkili merciye başvurmak suretiyle düzelttirmiștir. Buradaki mesele; davalı tarafin, dava açılmadan önce resmi olarak düzenlenen sözleşmedeki herhangi bir hatayı düzelttirmeye hakkı ve yetkisinin bulunup, bulunmadı̆̆ ; ĕger düzeltme yapılmış ise bu düzeltmenin sözleşme dışııdaki üçüncü kişilere etki edip etmeyeceğidir. Taşınmaz mal mülkiyetinin kanundan kaynaklanan daraltımlarından biri olan önalım hakkıla ilgili yorumların ve değerlendirmelerin, mülkiyet hakkının özüne zarar verecek şekilde önalım hakkı sahibi lehine genişletilmesi doğru değildir. Bu nedenle, dava açılmadan önce gerçekleşen satış ve düzeltme işlemlerinin, bir bütün halinde ve hepsine eşit değer vererek mevcut durumun değerlendirilmesi gerekir. davasına konu satıș sözleșmesine ve buradaki bilgilere dayanarak talepte bulunan davacının, dava açlmadan önce bu sözlesmedeki bir hatanın düzeltilmesine yönelik davalı işlemini kabul etmemesi 4721 Sayılı Kanun'un 2. maddesinde ver alan dürüstlük kuralı ile bağdasmaz. Davanın 58.000,00TL satış bedeli üzerinden kabulü gerekirken, 9.240,00TL üzerinden kabulü hukuka uygun değildir. Davalı vekilinin karar düzeltme istemi açılklanan nedenle yerinde olduğundan hükmün yazılan gerekçe ile bozulması gerekmiştir...”, 14. HD, 2019/3186 E., 2020/4622 K., 7.9.2020 T. (http://www.kazanci.com.tr/. Erişim tarihi: 20.05.2021). Bu yönde bir diğer karar için bkz. 14. HD, 2016/14090 E., 2020/2342 K., 27.02.2020 T., Ruhi/Ruhi, s. 309-313. Bu karara konu olayda, harç tamamlama davanın açılmasından bir gün önce yapılmıştır.

115 6. HD, 4120/4582, 23.06.1975 T.. Tunaboylu, s. 397. Aynı yönde daha yeni tarihli bir diğer karar için bkz. 6. HD, 8042/8546, 21.09.1995 T., Tunaboylu, s. 379-380. Bu kararda da, şu ifadeler yer almaktadır: “...Dava konusu taşınmazların tapu kayıt örneklerine ve tapunun cevabi yazısına göre şuf'alı payların 13.12.1993 tarihinde 50.000.000TL. bedelle davaliya satıldiğl, davalının bu satış sebebiyle 2.000.000-lira harç ödediği anlaşılmaktadır. Şuf'a hakk 26.1.1994 tarihinde dava yolu ile kullanıldıktan sonra davalı 28.1.1994 günü 1.700.000.000-Lira üzerinde gerekli harcı yatırmıştır. Davanın açılmasından sonra davalının vergi dairesine müracaatla evvelce vaki bedel hakkındaki beyanı hilafi hakikat olduğundan bahisle satıș karșılı̆̆ 1 milyar 700 milyon lira üzerinde harc ödemis olması açılan şuf'a davasına etkili değildir. Şuf'alı payların bedeli tapuda 50.000.000-lira olarak yazllıdır. Davalı satım sözleşmesinde taraflardan biri olduğuna göre tapuda gösterilen bedelde muvazaa bulunduğunu iddia edemeyeceği gibi o iddiaya uyularak sonradan vergi ödenmesinin, davanın değerinin yükseltilmesinin ve ona göre harç ödenmesinin de sonuca etkili olamaz. Bu nedenle satım sözleşmesinde gösterilen bedel üzerinden şuf'a hakkının tanınmasına karar verilmesi 
taraflarındandır. Bu itibarla satış bedelinin daha fazla olduğunu ileri süremeyeceği gibi, sonradan vergisi ödenmek suretiyle arttırllan bedelle şefi sorumlu tutulamaz. Aksi kabul edilecek olursa şefi şuf'a hakkını kullanmaktan men edilmiş duruma düşürülmüş olur. Mahkemenin bu hususu göz önünde bulundurmadan yazılı şekilde hüküm tesisi, usul ve kanuna aykırıdır..." ifadesine yer verilmiştir.

Yargıtay, tespit ettiğimiz kadarıyla, kural olarak önalım hakkı sahibinin tapuda gösterilen düşük bedel üzerinden önalım hakkını kullanmasını kabul etmekte, gerçek bedelin yüksekliği iddiasını hakkın kötüye kullanımı olarak görmektedir. Bununla birlikte, alıcı kendisine dava açılmadan önce, düşük bedeli harç tamamlatmak suretiyle düzelttiyse, bu düzeltilmiş bedel üzerinden önalım hakkının kullanılacağını, önceki düşük bedel üzerinden kullanılması talebinin ise dürüstlük kuralıyla bağdaşmayacağını ifade etmektedir. Dolayısıyla buradaki kilit nokta, dava açılmadan önce bedelin düzeltilmiș olmasıdır. Zira dava açıldıktan sonra yapılan düzeltmeler bakımından, düzeltilmiş bedelin değil tapuda gösterilen düşük bedelin önalım bedeli olduğunu kabul etmektedir.

\section{c. Öğretideki Görüşler}

Öğretide, önalım hakk1 sahibinin kütükte düşük gösterilmiş bedel üzerinden hakkını kullanmasını savunan ya da yerinde bulan yazarlar olduğu gibi, aksine davalı alıcının ispat ettiği gerçek bedel üzerinden hakkını kullanması gerektiğini ifade eden yazarlar da mevcuttur.

Kronolojik olarak baktığımızda, ESENER, Yargıtay'ın, alıcının bedelin tapudaki miktardan fazla olduğunu iddia edemeyeceğine ilişkin bir içtihadına yollama yapmış, fakat Harçlar Kanunu'nda yapılan değişikliğe istinaden zaten rayiç bedelden aşağı satım yapılamayacağını, dolayısıyla alıcının artık tapu sicilinde tescil edilmiş bedele karşı bir iddiasının olamayacağını ifade etmiştir ${ }^{116}$. FEYZİĞ $L U$, tarafların kötüniyetinin olduğunu ama bunun esasen önalım hakkını kullanana değil, fazla harç vermemek gayesiyle Hazine'ye karşı olduğunu açıklamakta, önalım hakkı sahibinin gerçek bedel üzerinden hakkını kullanmasının istendiğini, bedelin düşük gösterilmesi

gerekirken bedelde muvazaa iddiasını davalı tarafindan öne sürmeye hakk olduğundan, bu yönde davacı tarafin iddiasının yerinde olmadığından söz edilerek 1 milyar 700 milyon lira karşılığında şuf'a hakkının tanınması hatalı görüldüğ̈̈nden davacı vekilinin karar düzeltme isteğinin kabulü gerekmiştir..." (6. HD, 1995/8042 E., 1995/8543 K., 21.9.1995 T.) (http://www.kazanci.com.tr/. Erişim tarihi: 21.05.2021).

116 Esener, s. 114 ve s. $67-68$ 
halinde, alıcıya gerçek bedeli ispat imkânı tanımanın daha mantıklı olacağını söylemektedir. Fakat nihayetinde, resmi işlemlere karşı temin edilmesi gereken güven ve şu veya bu sebeple tevessül edilen kötüniyetli hareketleri himaye etmemek gereğinin, alıcının önalım hakkı sahibine karşı gerçek bedeli ileri sürmesine cevaz vermeme fikrini tercih edilebilir bulduğunu ifade etmektedir ${ }^{17}$. ACEMOĞLU, eksik harç vermek için satım bedelini eksik gösteren tarafların sonradan bunu önalım hakkı sahibine karşı ileri sürmesini "Nemo auditur - hiç kimse kendi hukuka ve ahlaka aykırı davranışından hak çıkaramaz" kaidesiyle çeliştiğini ve her zaman hakkın kötüye kullanımı anlamına geleceğini savunmaktadır"118. ACEMOĞLU'nun "her zaman" hakkın kötüye kullanımı anlamına geleceğini vurgulamasının sebebi, TANDOĞAN'ın görüşünü eleştirmesidir. Şöyle ki, TANDOĞAN, muvazaanın üçüncü kişilere ileri sürülememesinin ancak böyle bir iddia ortaya atmanın hakkın kötüye kullanımı teşkil ettiği veya mülga TBK m. 18/2'deki gibi (TBK 19/2) kanunen açıkça öngörülmüş hallerde söz konusu olacağını, burada önalım hakkı sahibine karşı muvazaanın ileri sürülmesinde hakkın kötüye kullanımının olmadığını kabul etmektedir ${ }^{119}$. ACEMOĞLU, yazarın satım bedelini düşük göstermenin vergi kaçırma amacına yönelik olduğunu gözden uzak tuttuğunu, bu sebepten bedeli düşük gösteren kimsenin her zaman hakkını kötüye kullanmış olacağını savunmaktadır ${ }^{120} 121$.

ESENER/GÜVEN, bir Yargıtay kararına ${ }^{122}$ atıfla ödenen bedelin senette yazılı bedelden daha fazla olduğu kanitlansa bile, bu bedelin payı satandan istenemeyeceği, zira kimsenin kendi muvazaasına dayanarak hak iddia edemeyeceğini ifade etmektedir ${ }^{123}$. Atıf yapılan Yargıtay kararına konu olayda, bedelin tapuda düşük gösterilmesi fakat harici bir belgede gerçek bedelin yer alması, alıcının da gerçek bedeli ödemesi söz konusudur. Fakat kendisine karşı önalım hakkı kullanılmış ve tapudaki değer üzerinden ödeme

117 Feyzioğlu, s. 430-431.

118 Acemoğlu, Kevork: Eşya Hukuku Meseleleri, Filiz Kitabevi, İstanbul, 1970, s. 129, dipnot 9.

119 Tandoğan, s. 238.

120 Acemoğlu, s. 129, dipnot 9. ATAMULU da, burada hakkın kötüye kullanımı olduğu görüşüne katılmaktadır. Bkz. Atamulu, s. 233.

121 Hemen belirtelim ki, öğretide hakkın kötüye kullanımı gerekçesine dayanmaksızın alıcının önalım hakkı sahibine karşı bedelin tapudakinden fazla olduğunu ileri süremeyeceğini ifade eden yazarlar da mevcuttur. Bkz. Tekinay, s. 52; Gürsoy/Eren/Cansel, s. 487; Ertaş, s. 278; Oğuzman/Seliçi/Oktay-Özdemir, s. 434.

122 YHGK, 2011/13-173 E., 2011/291 K., 11.5.2011 T. (http://www.kazanci.com.tr/. Erişim tarihi: 25.09 .2020$)$.

123 Esener/Güven, s. 314. 
yapılıp taşınmaz önalım hakkı sahibi üzerine tescil edilmiştir. Alıcı, gerçek bedel ile kütükteki bedel farkı için taşınmazı satın aldığı kişilere karşı icra takibi yapmış, takip kesinleşmiş, bunun üzerine menfi tespit davası açılmıştır. Hukuk Genel Kurulu, uyuşmazlığın şufa hakkının kullanılması sebebiyle taşınmazı geri alınan davalının, ödediği satış bedelinin taşınmazın tapudaki değerinden fazla kısmını, satıcı davacılardan sebepsiz zenginleşme hükümlerine göre isteyip isteyemeyeceği noktasında toplandığ 1 belirtmiştir. Menfi tespit davasının davalısı alıcının uğramış olduğu zararın, harici sözleşme gereğince kararlaştırılan bedelin ödenmesinden değil, tapu masrafından kaçınmak için eksik satış bedeli bildirmekten ileri geldiğini, davalının bu eyleminden dolayı kendi kusuru ile zarar gördüğünü, hukukun temel ilkelerine göre hiç kimse kendi kusurundan kendisi lehine sonuç çıkaramayacağ 1 için uğramış olduğu zarara kendisinin katlanmak zorunda olduğuna hükmetmiştir $^{124}$.

ADAY, bu hususta ileri sürülen görüşlere yer verdikten sonra, TANDOĞAN'a da yollama yaparak ${ }^{125}$ ispatın sorun teşkil edeceğini söylemektedir. TANDOĞAN, “...yalnız muvazaanın nasıl ispat edilebileceği ayrı bir sorundur..." demektedir. Onun bulduğu çözüm, rayiç bedelin öne sürülebilmesidir. Buna karşı1ık, ADAY, satışın rayiç bedel üzerinden yapılmış sayılacağı hususunda fiili veya hukuki bir karine olmadığı, öte yandan, tarafların satışın yüksel bedelle yapıldığını belgelendirmek üzere kendi aralarında düzenlemiş oldukları bir muvazaa senedini önalım hakkı sahibine karşı delil olarak kullanabilmesine izin vermenin işlem güvenliğini zedeleyeceğini ifade etmektedir. ADAY'ın önerdiği çözüm, önalım hakkı sahibine karşı gerçek bedeli ispat edemeyen alıcının, satıcıya rücu ederek muvazaayı taraflar arasındaki ispat rejimine göre ispat edip fazladan ödediği miktarın iadesini ondan (satıcidan) istemesidir. Satıcının bu sonuca katlanmak zorunda olduğunu ifade etmektedir ${ }^{126}$. Fakat önceki paragrafta yer verdiğimiz üzere, Yargitay bu yöndeki talebi kabul etmemiştir ${ }^{127}$.

124 “... Diğer taraftan, kural olarak, muvazaalı işlemin tarafları birbirine karşı kendi muvazaasına dayanarak talepte bulunabilir, üçüncü kişilere karşı bu durumu ileri süremezler ise de, somut olayda olduğu gibi tapuda bedelin düşük gösterilmesi suretiyle yapılan muvazaa taraflar arasındaki muvazaa niteliğinde olmadı̆̆ından bu tür bir muvazaaya dayanılarak talepte bulunulması olanaklı değildir...”. YHGK, 2011/13-173 E., 2011/291 K., 11.5.2011 T. (http://www.kazanci.com.tr/. Erişim tarihi: 25.09.2020). $\mathrm{Bu}$ karar için karar düzeltme talep edilmiş ancak talep reddedilmiştir. Bkz. YHGK, 2011/13-743 E., 2011/721 K., 30.11.2011 T. (http://www.kazanci.com.tr/. Erişim tarihi: 25.09.2020).

125 Bkz. Tandoğan, s. 238.

126 Aday, s. 81-82.

127 Bkz. Yukarida, dipnot 124. 
Davalı alıcının gerçek bedeli ispat edebilmesi ve önalım hakkı sahibinin de gerçek bedel üzerinden hakkını kullanması gerektiğini savunan görüşe baktığımızda, ilk olarak SEBÜK ${ }^{128}$ ün Yargıtay'ın aksi yöndeki kararına atıf yaptıktan bu hal tarzını isabetli görmediği yönündeki açıklaması mevcuttur. Ancak herhangi bir gerekçe ortaya koymamıştır.

İlk görüşü ifade ederken de yer verdiğimiz üzere, TANDOĞAN, muvazaanın üçüncü kişilere karşı ileri sürülememesinin ancak böyle bir iddia ortaya atmanın hakkın kötüye kullanımı teşkil ettiği veya kanunen açıkça öngörüldüğü hallerde (mülga TBK m. 18/2/ TBK m. 19/2) söz konusu olacağını, burada önalım hakkı sahibine karşı muvazaanın ileri sürülmesinde hakkın kötüye kullanımının olmadığı ifade etmiştir. Asıl sorunun muvazaanın ispatı meselesi olduğunu fakat rayiç bedel üzerinden hak kullanımı yoluna gidilerse deyim yerindeyse ispat probleminin de halledilmiş olacağ 1 söylemiştir ${ }^{129}$.

Tespit edebildiğimiz kadarıyla bu husustaki en geniş incelemeyi SUNGURBEY yapmışıır'130. Öncelikle Yargıtay'ın bu yöndeki kararlarına yer vermiş, bu içtihat sebebiyle uygulamada "şuf' azedeler" diye adlandırılabilecek bir topluluğun ortaya çıktığını, bu kişiler içinde varını yoğunu verip satın aldığı taşınmaz payının önalım hakkı sahibi tarafından yok bahasına elinden alınmak istenenler olduğunu söylemiştir. Resmi senette satı̧̧ bedelinin düşük gösterilmesine karşı bu davranışları önleyip Hazine'nin çıkarlarını korumak için yapılması gerekenin cezalı harç almak olduğunu, önalım hakkı sahiplerinin düşük bedelle önalım konusunu alabileceğini kabul ederek alıcıyı cezalandırmanın Medeni Hukukun görevi olmayacağını, keza önalım hakkı sahibinin bedeldeki düşüklük tutarında sebepsiz zenginleştirildiğini ifade etmiştir ${ }^{131}$. Öte yandan, yukarıda da incelediğimiz üzere ${ }^{132}$, Yargıtay miras hukukuna müteferri amaçlarla akrabaya yapılan muvazaalı temliklerde, alıcıya bu muvazaayı ileri sürüp ispatlama hakkı tanımaktadır, fakat bedeldeki muvazaayı ispatlama hakkı tanımamaktadı1 ${ }^{133}$. Bu bağlamda, Yargıtay'ın 1948 tarihli oy çokluğuyla alınmış bir kararına ve o karardaki muhalefet şerhine de yollama yaparak ${ }^{134}$ bedelin çok gösterilmiş olması

Sebük, s. 89.

Tandoğan, s. 238.

Sungurbey, İsmet: Medeni Hukuk Sorunları, Beşinci Cilt, İstanbul Üniversitesi Yayınlarından, İstanbul, 1984, s. 315-343.

131 Sungurbey, s. 323-324.

132 Bkz. Yukarıda I, C, 2.

133 Sungurbey, s. 318-319 dipnot 1.

134 “... Şuf'a hakkl, iddia olunan gayrimenkulün satış bedelinin 4 bin lira olduğu tapu cevabiyle anlaşılmasına ve bu gibi şuf'a davalarında müşterinin tapu memuru huzu- 
halinde, önalım hakkı sahibine gerçek bedeli ispat hakkı verildiğine göre, alıcıya da gerçek bedeli ispat hakkı verilmesi gerektiğini ifade etmektedir ${ }^{135}$. Bundan başka, Yargıtay'ın söz konusu kararda, alıcının önalım hakkı sahibine karşı bu bedelin gerçekte daha çok olduğu yolundaki savunmasını TMK m. 2/2'deki hakkın kötüye kullanımının özel bir çeşidi olan "çelişkili davranış yasağına" aykırı saydığının anlaşıldığın $1{ }^{136}$; fakat bunun söz konusu olabilmesi için bu yasağa dayanmak isteyen kişide haklı bir güven yaratılmış olması gerektiğini, bununla beraber düşük harç ödemek için satış bedelinin düşük gösterilmesi uygulamasının çok yaygın olması ve herkesçe bilinen bu gerçek karşısında, önalım hakkı sahibinin bu bedele güvenmesinin haklı bir güven olamayacağını söylemektedir ${ }^{137}$. Esasen, hakkın kötüye kullanılması yasağının tali - ikinci derecede ve düzeltici bir işlevi varken, bu yasaktan dem vurup önalım hakkı sahibinin, önalım konusu alıcıya kaça mal olmuşsa; ancak o bedeli ödeyerek alabileceği yolundaki hakkaniyete dayanan ve bu nedenle uygulanması mümkün ve zorunlu olan bir temel hukuk ilkesini bertaraf etmesi söz konusu olamaz ${ }^{138}$. SUNGURBEY'e göre, önalım hakk1 sahibinin resmi satış senedinde bedelin düşük gösterilmiş olmasını fırsat bilip önalım konusunu bu düşük bedelle alıp kendi malvarlığında sebepsiz zenginleşmeye kalkışması hakkın kötüye kullanımının "kürsü örneği” olacak kadar tipik bir örneğidir. Öte yandan bir kimsenin hukuki işlem yaparken

runda tapu memuru huzurunda tapu bedelini eksik beyan etmesi hüsnüniyete delalet edemeyeceğine ve şuf'a bedelinin davadan sonra yapılan ihbar üzerine idarece yapılan tahkikat neticesinde 13 bin lira olarak kabulü ile cezai harç alınması bedel hakkındaki tapu kaydına tesiri olmayacağına göre, ferağ bedelinin 4 bin lira olduğu kabul edilmek lazım gelirken ...". 1. HD, 1546/3215, 1.6.1948 T. Bu karar için bkz. Feyzioğlu, s. 428429. “... Bu müdafaa, vergiden kurtulmak için bedelin sözleşmede az gösterilmiş olması ahlaka mugayirdir, denerek dinlenmemezlik edilemez ve şuf'a davacisina vergiden kurtulmak maksadiyla bedelin sözleşmede az gösterilmiş olmasına rağmen, sözleşmede yazılı miktar ile şuf'alı hisseyi almak hakkı verilemez. Çünkü şuf'a hakkı davacısı, müşterinin yerini tutmak istemektedir. Bunun içindir ki, müşteri iktisap için mamelekinden ne çıkarmışsa, şuf'a davacısı da onu vermeye mecburdur. Bedelin çok gösterilmiş olması halinde şuf'a davacısına hakiki vaziyeti ve bedeli ispat ederek o miktarı almak yetkisinin tanınması da bu düşünceyi teyit eder. Şuf'a hakkı sahibine bu yetkinin tanınıp müşteriye tanınmaması için hiçbir hukuka uygun sebep gösterilemez... " Bu muhalefet şerhi için bkz. Feyzioğlu, s. 423-426.

135 Sungurbey, s. 331-332.

136 Sungurbey, s. 329.

137 Sungurbey, s. 332-333. Belirtmek gerekir ki, ACEMOĞLU da bu hususta hakkın kötüye kullanımı olduğunu kabul etmektedir ancak o, çelişkili davranış yasağına aykırılık değil; hiç kimsenin kendi hukuka ve ahlaka aykırı davranışından hak çıkaramayacağı ilkesine aykırılık olduğunu ifade etmektedir. Bkz. Acemoğlu, s. 129, dipnot 9.

138 Sungurbey, s. 334. 
sahip olduğu bir olanaktan aşırı çıkar sağlayacak şekilde yararlanması mülga BK m. 20 anlamında ahlaka aykırılık teşkil eder. Düşük bedel üzerinden önalım hakkı kullanarak kurulan satım ilişkisi de mülga BK m. 20 uyarınca ahlaka aykırılık sebebiyle batıldır ${ }^{139}$. Yazar bu noktada 6. Hukuk Dairesi'nin bir kararına yer verip kararı da çokça övmüştür ${ }^{140}$. Şöyle ki; karara konu olaydan anlaşıldığı kadarıyla kütükte 660 lira bedel belirlenmiş, önalım davası açılmış, davalılar bedelin gerçek olmadığından bahisle 4000 lira üzerinden harç vermişlerdir. Fakat bu husus sonuca etkili olmamıştır. Zira Yargıtay “... davacının satışın hakikatte 4000 lira üzerinden yapıldığından haberdar olduğu ve suiniyetle hareket ettiğini de iddia etmemiş olmalarına göre gerek mahkemenin görevine ve gerekse bedele mütedair temyiz itirazları varit görülmemiştir...” diyerek hüküm kurmuştur. Karşıt kavram üzerinden gidersek, davalılar tarafindan davacının kötüniyetli olduğu iddia edilmiş olsaydı bu hususun dikkate alınacağı fakat bunun iddia edilmediği sonucuna varmak mümkündür. Yargıtay'ın kötüniyetli olmaktan kast ettiği hakkın kötüye kullanımı ise, bu hususun dermeyan edilmese bile hâkim tarafından re'sen dikkate alınması gerekir. Muvazaanın iyiniyetli kimselere karşı ileri sürülemeyeceği kast ediliyorsa, bunun için de TBK m. 19/2 veya TMK m. 1023 gibi, açık kanun hükmü gerekir ${ }^{141}$. Karara konu olayla ilgili böyle bir hüküm de söz konusu değildir.

AYBAY/HATEMİ de, önalım hakkını düşük bedelle kullanmaya kalkışan davacıya karşı bedelin gerçek miktarını ispatlama hakkı verilmesi gerektiğini, verilmediği takdirde, satıcı ve alıcının anlaşıp satıcının alıcıya karşı muvazaalı gabin davası açtığını ifade etmektedirler ${ }^{142}$. AYAN da, dürüstlük ilkesinin (TMK m. 2) gerekli kıldığ 1 hallerde gerçek bedelin ileri sürülebileceğini kabul etmenin daha uygun düşeceği görüşündedir ${ }^{143}$.

TAMAN ŞIPKA da, öncelikle bu husustaki görüşlere yer vermiştir ${ }^{144}$. TANDOĞAN'ın hakkın kötüye kullanımı teşkil etmedikçe iddianın ispatına olanak verilmesi gerektiği görüşünden hareket edip gerçek bedelden ne anlaşılması gerektiği hususuna gelmiştir. Gerçek bedel taraflar arasındaki muvazaa anlaşmasına göre belirledikleri bedel mi, yoksa yapılacak keşif veya bilirkişi incelemesi sonucuna göre belirlenecek olan bedel midir sorusunu

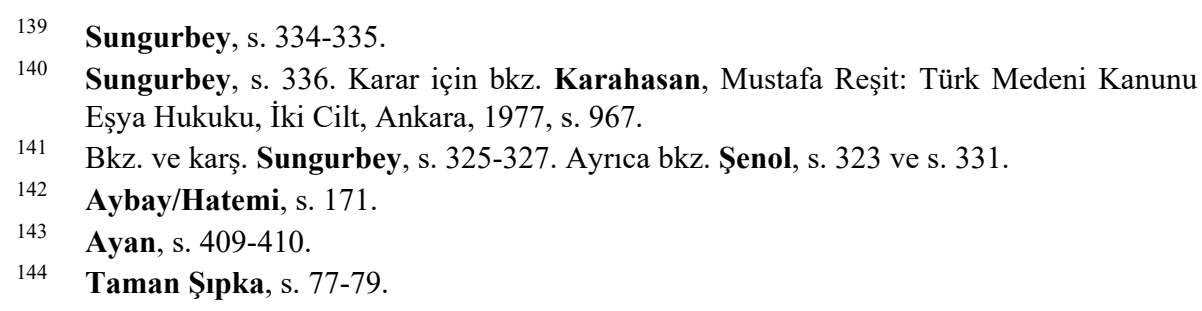


sormuştur. Tarafların kendi aralarında düzenlemiş oldukları muvazaa senedini önalım hakkı sahibine karşı kullanmalarını kabul etmenin sakıncalı olabileceğini ifade etmiş, tarafların rayiç bedelden çok yüksek senet yapmış olmaları halinde bunu ileri sürememeleri gerektiğini belirtmiştir. Nihayetinde, alıcının rayiç bedelin kütükte gösterilen bedelden daha yüksek olduğunu iddia etmesi de, muvazaa ileri sürmektir. Buna göre, önalım hakkı sahibi, tapudaki bedel rayiç bedelin çok üzerinde gösterilmişse, gerçek bedelin kütükteki bedel olmadığını, rayiç bedelin tespiti gerektiğini ileri sürebildiğine göre, ona karşı da rayiç bedelin tapuda gösterilen bedelden fazla olduğunun ileri sürülebilmesi gerekir. Aksi durum, önalım hakkı sahibinin kendi hakkını bertaraf etmek amacıyla kararlaştırılmamış olan bir muvazaanın sonucundan kanunen ve ahlaken gerekmeyecek bir biçimde yararlandırılması sonucunu doğuracaktır ${ }^{145}$.

ERKAN da, önalım hakkı sahibinin düşük bedeli firsat bilip önalım hakkını kullanmasının dürüstlük kuralına aykırılık oluşturacağı görüşündedir. Tapu harç ve masraflarından kaçmak için bedelin düşük gösterilmesi açıkça kanuna (vergi kanunlarına) aykırıdır fakat bunun sonucunda o hukuk kuralının gerektirdiği sonuçla karşılaşmalıdır. Vergi kanunlarına aykırı bir sözleşme, hukuka aykırı olduğu için geçersiz de olsa, nihayetinde vergi cezası uygulanmak suretiyle bu sözleşme ayakta tutulmaktadır. Bu bağlamda, alıcının hukuk düzeninin ayakta tuttuğu sözleşme için önalım hakkının rayiç bedel üzerinden kullanılmasını ileri sürmesi hakkın kötüye kullanımı anlamına gelmez. Hukuka aykırı davranan kişinin cezası vergi cezası ödemesidir, bundan başka bir de önalım hakkı sahibine düşük bedelle önalım hakkı kullanma imkânı vermek biçiminde ikinci bir ceza, hukuk sistemimizde öngörülmemiştir ${ }^{146}$. EREN de aynı hususa işaret etmekte, Yargıtay'ın önalım hakkının kütükteki bedel üzerinden kullanılması gerektiğine yönelik bir kararına yollama yaptıktan sonra bu görüşe mutlak olarak katılmanın mümkün olmadığını söylemektedir. Zira vergi kanunları düzeltme ve pişmanlık hakkı tanımaktadır. Buna göre, bir hukuk düzeninde bizzat yasa hükmü sözleşmede yapılan bedelde muvazaayı ek harç ve vergi ödemek suretiyle düzeltiyorsa, yargı organının bu sözleşmeyi artık muvazaalı saymasına imkân yoktur $^{147}$.

ŞENOL, satım sözleşmesinde bedel objektif esaslı unsurlardan biri olduğu için basit kısmi hükümsüzlüğün söz konusu olamayacağını, zira

\footnotetext{
145 Taman Şıpka, s. 79.

146 Erkan, s. 59.

147 Eren, s. 112-113.
} 
bedelin geçersiz olup sözleşmenin diğer hükümlerinin ayakta kalacağının iddia edilemeyeceğini ifade etmiştir. Değiştirilmiş kısmi hükümsüzlük ${ }^{148}$ bakımından değerlendirip bu tür hükümsüzlük türünde geçersiz olan hükmün yerine yedek bir kuralın geçebileceği ve sözleşmedeki boşluğun bu şekilde doldurulabileceği üzerinden gitmiştir. Buna göre, yedek hüküm, emredici bir kural, tamamlayıc bir kural veya tarafların ortak ve farazi iradesi olabilir. Bedelde muvazaa halinde bedelin geçersiz, sözleşmenin geri kalan hükümlerinin geçerli olarak ayakta kaldığı varsayımında ise, taşınmaz satış sözleşmesinde bedelin yerine geçecek bir emredici veya yedek hukuk kuralı söz konusu değildir. Ancak yazara göre, tarafların farazi iradesi ile bu boşluğun doldurulması hususu tartışılabilecektir. Bedelde muvazaada tarafların görünürde yaptıkları işlem dışında, aralarında yaptıkları ve gerçek bedeli içeren bir de gizli işlem bulunmaktadır. Bu işlem şekle aykırılık sebebiyle geçersiz olması ve fakat bu geçersizliğin taraflar arasında TMK $2 / 2$ gereği ileri sürülemeyecektir. Buna karşılık, değiştirilmiş kısmi hükümsüzlük yaptırımının kabul edilmesi halinde, taraflar arasındaki gizli işlemdeki bedele ilişkin irade gerçek iradelerini yansıttığ 1 için, ortak irade olarak kabul edilerek hükümsüz bölümün veya diğer bir ifadeyle objektif esaslı noktanın yarattığı boşluğun bu gerçek irade ile dolduğu kabul edilebilir. Bu hükümsüzlük türünün bedelde muvazaa için kabul edilmesi durumunda, görünürdeki işlemin hükümsüz olan bedel unsuru gizli işlemdeki bedel unsuru ile doldurulacak; ancak, üçüncü kişi konumundaki kişiler bakımından uygulanacak bedel, rayiç emlak vergisi değeri üzerinden hesaplanacaktır. ŞENOL bu değerlendirmesindeki amacının, borçlar hukuku prensiplerine göre kesin hükümsüz olan bir sözleşmenin zorla ayakta tutulmaya çalışılması olmadığını, uygulamada bedelde muvazaa halinde geçersizlik yaptırımının tam olarak uygulanmıyor olmasından kaynaklanan hukuki durumu temellendirme çabası olduğunu ifade etmektedir ${ }^{149}$.

\section{d. Görüşümüz}

Önalım hakkı sahibinin tapuda gösterilen düşük bedel üzerinden önalım hakkını kullanması hususundaki görüşümüzü konuyu ikiye ayırarak değerlendirmek istiyoruz. Şöyle ki, Yargıtay yukarıda yer verdiğimiz üzere, bedelin dava açılmadan önce harç tamamlatmak suretiyle düzeltilmesi halinde

148 Bu hususta geniş bilgi için bkz. Başpınar, Veysel: Borç Sözleşmelerinin Kısmi Butlanı, Banka ve Ticaret Hukuku Araştırma Enstitüsü, Ankara, 1998, s. 152 vd.; Kırkbeşoğlu, Nagehan: Türk Özel Hukukunda Kısmi Hükümsüzlük, Vedat Kitapçılık, İstanbul 2011, s. $203 \mathrm{vd}$.

149 Şenol, s. 333-334. 
düzeltilmiş bedel üzerinden kullanıma imkân vermektedir. Biz bu hususa ilişkin değerlendirmemizi sonraya bırakarak önalım hakkı sahibinin hakkını gerçek bedel mi yoksa tapudaki düşük bedel üzerinden mi kullanmasının hukuka uygun olduğu meselesini öncelikle değerlendirmek istiyoruz.

Esasen, yukarıda da yer verdiğimiz üzere ${ }^{150}$, muvazaanın üçüncü kişiye karşı ileri sürülmesini engelleyen açık bir kanun hükmü olmadığ takdirde bu sonucu doğuracak hüküm TMK m. 2/2 hakkın kötüye kullanımı yasağıdır. Yani muvazaayı ileri sürmek ancak hakkın kötüye kullanımı anlamına geliyorsa, sonuç doğurmayacak, bir başka ifadeyle hakkını kötüye kullanan elde etmek istediği sonuca ulaşamayacaktır. Yani kütükteki bedelin gerçek olmadığııı, gerçek bedel üzerinden önalım hakkının kullanılması gereğini ifade eden davalı alıcı, hakkını kötüye kullanıyorsa, bu iddia dinlenmeyecek ve kütükteki değer üzerinden önalım hakkı kullanılacaktır. Öğretide tapuda gösterilen bedelin gerçek bedel olmadığını önalım hakkı sahibine karşı ileri sürmenin hakkın kötüye kullanımı anlamına gelmeyeceğini savunan yazarların başında TANDOĞAN gelmektedir. Hemen ifade edelim ki, kanaatimizce de gerçek bedeli önalım hakkı sahibine karşı ileri sürmek kural olarak hakkın kötüye kullanımı teşkil etmez.

Hakkın kötüye kullanımının söz konusu olması için, hukuk düzeninin tanıdığ 1 bir hakkın varlığ 1 ve bu hakkın açıkça kötüye kullanılması gereklidir. Bu kötüye kullanmadan bir zararın hâsıl olmasının gerekip gerekmediği ise tartışmalıdır. Buna göre, davalı alıcının hakkını kötüye kullandığını söyleyebilmek için, öncelikle hukuk düzeninin tanıdığı bir hakkın varlığı aranır. Edimler ifa edildikten sonra bedelin muvazaalı olduğunu sözleşmenin diğer tarafına karşı dermeyan etmekte hakkın kötüye kullanımının olduğu kanaatindeyiz. Nihayetinde tarafların edimlerini yerine getirdikten sonra, hükümsüzlügü ileri sürüp geçersiz sözleşmenin tasfiyesini talep etmelerinde yani bedelin ve taşınmazın iadesini istemelerinde menfaatlerinin en azından haklı bir menfaatlerinin olmadığı açıktır. Bir başka ifadeyle, hükümsüzlük ileri sürme hakkını kullanmakta yarar yokluğu söz konusudur. Bundan başka, bu halde bir tarafin diğer tarafı aldatıp şekle aykırılığa sebep olması durumu da mevcut değildir. Esasen bu halde konunun mahkeme önüne gitmesi de gerçek bedelin eksik ödenmesi yani edimlerin ifasının tamamlanmadığı hallerde gerçekleşmektedir. Hemen belirtelim ki, bedel sözleşmenin esaslı unsurudur ve kanaatimizce Yargıtay'ın “Taraflar görünüşteki sözleşmeyi yapmayı ciddi olarak istemekte ve niteliğinde de anlaşmaktadırlar. Sadece sözleșmenin

150 Bkz. Yukarıda I, B, 3, a. 
bedeli değiștirilmektedir $^{151}$ " ifadesiyle ortaya koyduğu üzere, önemsiz görülecek ve geçiştirilecek bir husus değildir. Burada medeni hukuk bağlamındaki çözüm, hakkın kötüye kullanımının korunmamasıdır. Hak kötüye kullanılıyorsa hükümsüzlük dikkate alınmayacak, hükümsüzlük dermeyanıyla elde edilmek istenen sonuca ulaşılamayacaktır. Aksi halde ise ileri sürülebilecektir.

Tarafların düşük harç, vergi ödemek için bedeli de düşük göstermiş olmaları halinde davalı alıcının bu hususu davacı önalım hakkı sahibine ileri sürmesinde yani bedelin muvazaalı olduğunu söyleyip gerçek bedeli ispat edip önalım hakkının bu bedel üzerinden kullanılmasını istemesinde kötüye kullanılan bir hak olduğu kanaatinde değiliz ${ }^{152}$.

ACEMOĞLU, eksik harç vermek için satım bedelini eksik gösteren tarafların sonradan bunu önalım hakkı sahibine karşı ileri sürmesini "Nemo auditur propriam turpitudinem allegans - hiç kimse kendi hukuka ve ahlaka aykırı davranışından hak çıkaramaz" kaidesiyle çeliştiğini ve her zaman hakkın kötüye kullanımı anlamına geleceğini savunmuştur ${ }^{153}$. Tarafların bedeli eksik göstermelerinin hukuka aykırı olduğu açıktır. Ne var ki, bizatihi Devlet bu hukuka aykırılığı yani tarafların yalan beyanını deyim yerindeyse affedip onlara düzeltme imkânı tanımaktadı1 ${ }^{154}$. Öte yandan, tarafların amacı üçüncü kişileri yani önalım hakkı sahiplerini aldatmak da değildir.

Buna karşılık, önalım hakkı sahibinin tapuda gösterilen düşük bedel üzerinden önalım hakkı kullanmaya çalışması bakımından hakkın kötüye kullanımı halini irdelemek gerekir. Çok defa tapudaki bedelin piyasadaki rayiç bedelden düşük olduğunu bildiği ve davalı tarafından da bu husus ileri sürüldüğü halde, tabiri caizse kütükte gösterilen düşük bedeli firsat bilip önalım hakkını bu değer üzerinden kullanmakta hakkın kötüye kullanımı söz konusu olabilecektir ${ }^{155}$ 156. Hakkın kötüye kullanımından bir zarar ortaya

151 YHGK 2011/13-716 E.; 2012/106 K.; 29.2.2012 T. (http://www.kazanci.com.tr/. Erişim tarihi: 29.04.2021).

152 Hatta SUNGURBEY'in ifade ettiği üzere, üçüncü kişinin yani önalım hakk1 sahibinin kütükteki bedelin gerçek bedel olduğunu düşündüğü, böyle düşünmekte de haklı olduğu bir başka ifadeyle iyiniyetli olduğu halde ona karşı bedelde muvazaanın ileri sürülemeyeceğini kanaatinde de değiliz. Zira iyiniyetin korunması ancak Kanunun iyiniyete sonuç bağladığı hallerde söz konusu olur. Halbuki burada örneğin TBK m. 19/2 gibi bir hüküm mevcut değildir. Bkz. Sungurbey, s. 325-327.

153 Acemoğlu, s. 129, dipnot 9.

154 Bu hususta ayrıntılı bilgi için bkz. Şenol, s. 313-318.

155 Yargıtay kararına konu olan ve yukarıda da yer vermiş olduğumuz bir olayda, davacı önalım hakkı sahibi daha önce aynı taşınmazın 1/3 payını, önalım hakkı kullanmak istediği pay için tapuda öngörülen bedelden çok daha yüksek bir bedele satın almış ve 
çıkması gerekip gerekmediği tartışmalı bir husustur ancak burada davalı alıcının zarara uğrayacağ 1 da açıktır. Hatta bu durum, SUNGURBEY'in ifadesiyle, hakkın kötüye kullanımının "kürsü örneği" olacak kadar tipik bir örneğidir ${ }^{157}$.

TANDOĞAN bedeli düşük gösterme hususunda esas sorunun ispat olduğunu, bu nedenle rayiç bedel üzerinden hakkın kullanımının sorunu çözeceğini ifade etmiştir. İspat hususunda sözleşme tarafının muvazaayı ispat etmesi yazılı delili, daha doğrusu bir ifadeyle kesin delili gerektirecektir. Önalım davasının davalısı alıcının elinde bedelde muvazaayı ispat eden bir yazılı belge olması halinde ispat gerçekleşecektir. İspatın gerçekleştiği halde de rayiç bedeli tespite gerek kalmayacaktır.

Esasen sorununun rayiç bedelle çözüleceğini düşünen tek yazar TANDOĞAN değildir. ESENER, gerçek bedelin önalım hakkı sahibine karşı ileri sürülemeyeceğini ifade etmesine rağmen, Harçlar Kanunu'nda yapılan değişiklikle, rayiç bedelden aşağı satış yapmak mümkün olmadığından alıcının artık tapu sicilinde tescil edilmiş bedele karşı bir iddiasının olamayacağını ifade etmiştir. Önceki bölümde yer verdiğimiz üzere önalım hakkı sahibinin kütükteki düşük bedel üzerinden hakkını kullanmasını yerinde bulmayan hemen hemen bütün yazarlar, rayiç bedel üzerinden kullanımın sorunu çözeceği kanaatindedir. Bu bağlamda TAMAN ŞIPKA, önalım hakkı sahibi, tapudaki bedel rayiç bedelin çok üzerinde gösterilmişse, gerçek bedelin kütükteki bedel olmadığını, rayiç bedelin tespiti gerektiğini ileri sürebildiğine göre, ona karşı da rayiç bedelin tapuda gösterilen bedelden fazla olduğunun ileri sürülebilmesi gerektiği görüşündedir. Bununla birlikte, ADAY ${ }^{158}$, FEYZİĞLU ${ }^{159}$ 'nun da bir anlamda kaygısını paylaşarak şöyle

fakat yeni pay için düşük bedel üzerinden önalım hakkı kullanmıştır. Buna rağmen, davalının, davacı önalım hakkı sahibinin hakkını kötüye kullandığı iddiası Hukuk Genel Kurulu tarafından kabul görmemiştir. YHGK 2014/14-292 E., 2015/1544 K., 10.6.2015 T. (http://www.kazanci.com.tr/. Erişim tarihi: 02.10.2020).

156 Nitekim bu yönde bkz. Aybay/Hatemi, s. 171; Ayan, s. 409-410; Taman Şıpka, s. 79. Erkan, s. 59; Eren, s. 112-113.

157 SUNGURBEY, önalım hakkı sahibinin hakkını nasıl kötüye kullandığını çarpıcı örneklerle ve bütün unsurlarıyla açıklamıştır. Bkz. Sungurbey, s. 315-343, s. 334-335.

158 ADAY, tarafların satışın yüksel bedelle yapıldığını belgelendirmek üzere kendi aralarında düzenlemiş oldukları bir muvazaa senedini önalım hakkı sahibine karşı delil olarak kullanabilmesine izin vermenin işlem güvenliğini zedeleyeceğini ifade etmektedir. Bkz. Aday, s. 81-82.

159 FEYZİOĞLU, resmi işlemlere karşı temin edilmesi gereken güven ve şu veya bu sebeple tevessül edilen kötüniyetli hareketleri himaye etmemek gereğinin, alıcının önalım hakkı sahibine karşı gerçek bedeli ileri sürmesine cevaz vermeme fikrine tercih edilebileceği görüşündedir. Bkz. Feyzioğlu, s. 430-431. 
bir yorum da getirmiştir: Yazara göre, tarafların kendi aralarında düzenlemiş oldukları muvazaa senedini önalım hakkı sahibine karşı kullanmalarını kabul etmenin sakıncası olabilir, bu nedenle, taraflar rayiç bedelden çok yüksek senet yapmış olmaları halinde bunu ileri sürememelidir. Önalım hakkı sahibinin hakkını kullanma ihtimalini gözetip bir muvazaa senedi de hazırlayan ve bu senette ödenen bedelden de fazla bir bedel gösteren kişinin bunu ileri sürememesi gerektiği açıktır. Nihayetinde bunun önalım hakkı sahibinin hakkını kullanamaması veya yüksek bedelden kullanması için, kütükte gerçek bedelden yüksek bir bedel göstermekten farkı yoktur.

Bununla birlikte, "rayiç bedel" de esasen sorunu çözmemektedir. Bu noktada rayiç bedel ifadesiyle neyin kast edildiğini önemlidir. Şöyle ki, tapuda bildirilecek olan asgari değer emlak vergisi değeridir. Emlak vergisi değeri de, taşınmazın asgari değeri üzerinden bir bölgede belediye tarafından hesaplanan metrekare satış değeridir. Buna karşılık, taşınmazın gerçek satış değeri gerçek rayiç değeridir. Çoğunlukla da taşınmazın gerçek rayiç değeri, belediyenin tespit ettiği rayiç değerinden yüksektir ${ }^{160}$. Dolayısıyla "rayiç bedel" de bu hususta her zaman bir çözüm olamayabilecektir.

ŞENOL, bedelde muvazaa halinde değiştirilmiş kısmi hükümsüzlük yaptırımının uygulanması gerektiği kanaatindedir. Öncelikle belirtelim ki, görünürdeki düşük bedel gösterilmiş işlem muvazaa sebebiyle, gizli işlem ise şekle aykırılık sebebiyle geçersizdir. Fakat tarafların edimlerini ifa ettikten sonra geçersizliği ileri sürmesi hakkın kötüye kullanımı anlamına gelir. ŞENOL görünürdeki işlemin bedel unsurunun hükümsüz olduğunu, bedel esaslı nokta olduğu için, basit kısmi hükümsüzlük yaptırımının uygulanamayacağını, bu nedenle değiştirilmiş kısmi hükümsüzlük yaptırımının uygulanarak gizli işlemdeki bedel unsurunun görünürdeki işlemdeki boşluğu doldurması ve böylece hakkın kötüye kullanımından mütevellit geçersizlik yaptırımın söz konusu olmaması gerektiğini ifade etmektedir. Kanaatimizce, görünürdeki işlem muvazaa sebebiyle kesin hükümsüzdür. Bedel muvazaasında edimler ifa edildikten sonra bunu ileri sürmek de hakkın kötüye kullanımı teşkil etmektedir. Bu noktada medeni hukuk ilkeleri bakımından bir yanlışlık olduğu kanaatinde değiliz, keza bu husus yorumla değiştirilebileceğimiz bir konu da değildir, buna gerek de yoktur. Bundan başka, değiştirilmiş kısmi hükümsüzlük yaptırımın uygulanabilmesi için tarafların farazi iradelerinin, sakatllğ bilmiş olsalard $\iota$ sözleşmeyi ikame bir hükümle yapacakları sonucuna varılması gerekir ${ }^{161}$. Tarafların bedeli düşük gösterirken

160 Geniş bilgi için bkz. Şenol, s. 317 vd.

161 Başpınar, s. 162. 
bunun hukuka aykırı olduğunu veya sakat olduğunu bilmemeleri de kanaatimizce mümkün değildir. Esasen sorun tarafların birbirlerine karşı olan taleplerinden ziyade, alıcı üçüncü kişilere karşı taleplerinde ortaya çıkmaktadır. Yazarın o husustaki çözümü ise rayiç bedelin uygulanmasıdır ${ }^{162}$. Kanaatimizce değiştirilmiş kısmi butlan yaptırımını uygulamayı kabul ettikten sonra, üçüncü kişiler bakımından niye gizli sözleşmedeki bedelin değil de, bu çözümle çelişen bir biçimde rayiç bedelin uygulanması gerektiği açıklanmaya muhtaç bir konudur. Üstelik kendisinin ayrıntısıyla açıkladığı ve bizim de yukarıda yollama yaptığımız üzere ${ }^{163}$ Emlak Vergisi Kanunu'ndaki rayiç bedel, gerçek satış bedelinin çok altında olmaktadır.

Yargıtay'ın uygulamasına gelince, esasen Yargitay'ın görüşüne katılmadığımız zaten buraya kadar yaptığımız açılamalardan da ortaya çıkmaktadır. Fakat bu noktada Yargıtay'ın kendi içinde çelişkili içtihatlarını da dikkate aldığımızda bu uygulamayı benimseyenlerin bile yerinde bulmayacağını düşündüğümüz bir husus vardır. Yukarıda ifade ettiğimiz üzere, Yargıtay dava açılmadan önce harç tamamlatılmış olması halinde tamamlatılmış harca esas bedeli önalım bedeli olarak kabul etmektedir. Hatta bir kararında dava açılmadan bir gün önce - belki de dava açılacağından bir şekilde haberdar olunması üzerine - harç tamamlatılmış, ertesi gün de alıcıya dava açılmıştır. Şayet harç tamamlatılıp gerçek bedel üzerinden hak kullanımında hakkın kötüye kullanımı - hukuka aykırılık yoksa pekâlâ dava açılması üzerine de bunun mümkün olması gerekir. Açıkçası bir kimsenin kendi muvazaasına dayanamayacağ 1 argümanı, harç dava açılmadan tamamlatılırsa bu bedel üzerinden önalım hakkı kullanımını mümkün kılmaya göre daha kabul edilebilir bir gerekçedir.

Öte yandan, Yargitay, yine yukarıda yer verdiğimiz üzere, miras hukukuna müteferri amaçlarla yapılan fakat satış gösterilen bağış sözleşmelerinde önalım hakkının kullanılamayacağını kabul etmektedir. Üstelik bağışlanan kişilerin akraba olması yeterlidir, yani bu uygulama müstakbel mirasçılarla sınırlı da değildir. Bu halde, muvazaanın ileri sürülmesini kabul ederken, kimsenin kendi muvazaasına dayanamayacağı hususunu gözetmezken, önalım hakkı sahibinin, deyim yerindeyse, göz göre göre düşük bedel üzerinden hak sahibi olmasına -dava açılmadan önce harç tamamlatılmamışsahiçbir engel çıkarmamaktadır. Yargıtay'ın bu uygulamasının yerinde olmadığı düşüncesindeyiz.

162 Şenol, s. 333-334.

163 Bkz. Yukarıda dipnot 160. 


\section{SONUÇ}

Yargıtay bedel muvazaasının bir türü olarak karşımıza çıkan hatta muvazaanın en çok görülen türü olan tapuda gerçek bedelden düşük bedel gösterilmesi hususunda sözleşmeyi geçerli saymaktadır. Burada tarafların amacı düşük vergi ve harç ödeyip tapu masraflarını azaltmaktır. Esas itibariyle, bu hususun mahkeme önüne gelmesi de ancak taraflardan birinin edimini gereği gibi getirmemesi halinde söz konusu olmaktadır. Zira her iki taraf edimini yerine getirdikten sonra mahkemenin önüne gidecek bir çekişme ortaya çıkmayacağı gibi, bu halde geçersizliği ileri sürmek de hakkın kötüye kullanımı teşkil edecektir.

Yargıtay, kural olarak, önalım hakkı sahibinin de tapuda gösterilen düşük bedel üzerinden hakkını kullanacağını kabul etmektedir. Kişinin (önalım hakkı yükümlüsü alıcının) kendi muvazaasına dayanmasının hakkın kötüye kullanımı anlamına geleceğine istinaden bu şekilde hüküm vermektedir. Ancak miras hukukuna müteferri amaçlarla yapılan muvazaada, bağışın satış gösterilmesi halinde, bunun ileri sürülebileceğini kabul etmekte, dahası bağışlanan kişinin müstakbel mirasçı olmasını da aramamakta, akraba olmasını yeterli görmektedir. Bundan başka, son kararlarında gördüğümüz üzere, önalım hakkı kullanmak için dava açılmadan önce gerçek bedele göre harç tamamlatılmış olması halinde, önalım hakkının bu bedel üzerinden kullanılacağını kabul etmektedir. Yargıtay'ın burada dikkate aldığı husus davanın açılma tarihidir.

Kanaatimizce, önalım hakkı sahibine karşı alıcının gerçek bedelin kütükte görünenden daha yüksek olduğunu iddia etmesini, bir ön kabul olarak hakkın kötüye kullanımı saymak doğru değildir. Yargıtay, bu hallerde, hiçbir değerlendirme yapmadan, deyim yerindeyse ezbere biçimde hakkın kötüye kullanımı olduğunu söylemektedir. Ne var ki, incelememizde de gördüğümüz üzere, önalım hakkı sahibinin, bir payı, aynı taşınmazdan daha önce aldığ başka bir paya ödediği bedelden, çok daha düşük bedele önalım hakkını kullanmak suretiyle edinmesi bile söz konusu olmaktadır. Burada önalım hakkı sahibinin hakkını kötüye kullanıp kullanmadığının incelenmesi gerekmektedir. Bu nedenle Yargıtay'ın bu içtihadını yerinde bulmuyoruz. Öte yandan, yine belirttiğimiz üzere, Yargıtay, harcın dava açılmadan önce tamamlatılması halinde, bu bedel üzerinden hakkın kullanımını kabul etmekte, burada bir kötüye kullanma görmemektedir. Eğer böyle ise, davanın açılması üzerine, davalının talebi olması halinde, davalı alıcıya harç tamamlatma imkânı verilmesi, en azından kendi uygulamasındaki çelişkiyi ortadan kaldıracaktır. 


\section{BİBLIYYGRAFYA}

Acemoğlu, Kevork: Eşya Hukuku Meseleleri, Filiz Kitabevi, İstanbul, 1970.

Aday, Nejat: Taşınmaz Mülkiyetinin Naklinde Muvazaa, 1. Baskı, Kazancı Hukuk Yayınları, İstanbul, 1992.

Akalp-Demirtabak, Didem: Yasal Önalım Hakkı, 1. Baskı, On İki Levha Yayınları, İstanbul, 2010.

Akipek, Jale/Akıntürk, Turgut/Ateş, Derya: Eşya Hukuku, 2. Baskı, Beta Yayınevi, İstanbul, 2018.

Akyol, Şener: Dürüstlük Kuralı ve Hakkın Kötüye Kullanılması Yasağı, Filiz Kitabevi, İstanbul, 1995.

Alaslan, Fatma: "Medeni Hukuk'da Dürüstlük Kuralı ve Hakkın Kötüye Kullanılması Yasağı", Çankaya Üniversitesi Hukuk Fakültesi Dergisi, C. 1, S. 2, Ekim 2016, s. 413-434.

Altaş, Hüseyin: Medeni Hukuk Başlangıç Hükümleri (TMK m. 1-7), Yetkin Yayınevi, Ankara, 2014.

Altaş, Hüseyin: Şekle Aykırılığın Olumsuz Sonuçlarının Düzeltilmesi, Yetkin Yayınevi, Ankara, 1998.

Arık, K., Fikret: "Mirasçıya Satışta Suf'a Cereyan Eder mi?", Ankara Üniversitesi Siyasal Bilgiler Fakültesi Dergisi, C. 12, S. 4, s. 211-217.

Arpacı, Abdülkadir: "Eşya Hukukumuzda Yeni Medeni Kanunla Yapılan Değişikliklerden Bazılarına Kısa Bir Bakış", Prof. Dr. Necip KOCAYUSUFPAŞAOĞLU'na Armağan, Ankara, 2004, s. 89-113.

Atamulu, İsmail: Türk Borçlar Hukukunda Muvazaa, Adalet Yayınevi, Ankara, 2017.

Ateş, Derya: "Sözleşme Özgürlüğü Yönünden Dürüstlük Kuralları", TBB Dergisi, S. 72, 2007, s. 75-93.

Ayan, Mehmet: “Kanuni Şuf'a Hakkı” (Şuf’a), Prof. Dr. Halil CíN’e Selçuk Üniversitesinde 10. Hizmet Yılı Armağanı, Özel Say1, Konya, 1995, s. 335-368.

Ayan, Mehmet: Eşya Hukuku II, Mülkiyet, 9. Bası, Seçkin Yayınevi, Ankara, 2016.

Aybay, Aydın/Hatemi, Hüseyin: Eşya Hukuku, Vedat Kitapçılık, İstanbul, 2012.

Aydın Ünver, Tülay: "Yasal Önalım Hakkında Önalım Olayının Bildirilmesi”, Bahçeşehir Üniversitesi Hukuk Fakültesi Dergisi, C. 11, S. 145- 
146, Eylül Ekim 2016, Prof. Dr. Özer SELİÇİ'nin Anısına Armağan, s. 829-857.

Aydoğdu, Murat: Yasadan ve Sözleşmeden Doğan Önalım Hakkı, 1. Bask1, Adalet Yayınevi, Ankara, 2013.

Başpınar, Veysel: Borç Sözleşmelerinin Kısmi Butlanı, Banka ve Ticaret Hukuku Araştırma Enstitüsü, Ankara, 1998.

Baygın, Cem: "Yeni Borçlar Kanununun Satış İlişkisi Doğuran Haklar Konusunda Getirdiği Düzenlemelere Genel Bir Bakış", Bahçeşehir Üniversitesi Hukuk Fakültesi Kazancı Hakemli Hukuk Dergisi, Y. 2011, S. 79-80, s. 7-30.

Burcuoğlu, Haluk: “4721 Sayılı Türk Medeni Kanunu'nun Önalım Hakk1 Düzenlemesi ve Borçlar Kanunu'nun ve Türk Borçlar Kanunu Tasarısı'nın Sözleşmesel Önalım Hakkına İlişkin Düzenlemeleri Hakkında Bazı Gözlemler", Medeni Hukuk Hocalarına Saygı Günleri, Medeni Hukukta Güncel Sorunlar ve Önemli Gelişmeler Sempozyumu, 26-27 Haziran 2008, İstanbul, 2011, s. 285-298.

Buz, Vedat: Medeni Hukukta Yenilik Doğuran Haklar, Yetkin Yayınevi, Ankara, 2005.

Cihan, Ali Hulki: "Taşınmaz Devirlerinde Bedelde Muvazaanın Sözleşmeye Etkisi”, Akdeniz Üniversitesi Hukuk Fakültesi Dergisi, Aralık 2013, S. 2, s. 101-106.

Dural, Mustafa/Sarı, Suat: Türk Özel Hukuku, C. I, 12. Baskı, Filiz Kitabevi, İstanbul, 2017.

Edis, Seyfullah: Medeni Hukuka Giriş ve Başlangıç Hükümleri, 4. Baskı, Ankara Üniversitesi Hukuk Fakültesi Yayınları Ankara, 1989.

Erdem, Mehmet: "Yasal Önalım Bedeli ve Yargıtay İçtihatları Çerçevesinde Bedelin Güncellenmesi Meselesi”, Prof. Dr. Haluk BURCUOĞLU'NA Armağan, C. I, İstanbul, 2020, s. 789-832.

Erel, Şafak: Eşyaya Bağlı Borç, Ankara Üniversitesi Siyasal Bilgiler Fakültesi Yayınları Ankara, 1982.

Eren, Fikret: "Türk Medeni Kanununa Göre Yasal Önalım Hakkı", Gazi Üniversitesi Hukuk Fakültesi Dergisi, C. XII, Y. 2008, S. 1-2, s. 103126.

Eren, Fikret: Borçlar Hukuku Genel Hükümler (BG), 24. Bask1, Yetkin Yayınevi, Ankara, 2019.

Eren, Fikret: Mülkiyet Hukuku (Mülkiyet), Yetkin Yayınevi, Ankara, 2011. 
Erkan, Vehbi Umut: “Anayasa Mahkemesi'nin 12.12.2007 Tarihli E. 2003/ 34 ve K. 2007/ 94 Sayılı Kararı Üzerine: Türk Medeni Kanunu'nda Yasal Önalım Hakkının Hukuki Niteliği ve Kullanılması”, İnönü Üniversitesi Hukuk Fakültesi Dergisi C. 5, S. 1, Y. 2014, s. 269-294.

Erkan, Vehbi Umut: Türk Medeni Kanunu'nda Yasal Önalım Hakkı (MK. md. 732, 733, 734), Ankara, 2006 (Yayımlanmamış Yüksek Lisans Tezi).

Ertaş, Şeref: Eşya Hukuku, 11. Bask1, Fakülteler Yayınevi, İzmir, 2014.

Esener, Turhan/Güven, Kudret: Eşya Hukuku, 8. Bası, Yetkin Yayınevi, Ankara, 2019.

Esener, Turhan: Türk Hususi Hukukunda Muvazaalı Muameleler, Ankara Üniversitesi Hukuk Fakültesi Yayınları İstanbul, 1956.

Feyzioğlu, Feyzi Necmettin: Şuf'a Hakkı, Fakülteler Matbaası, İstanbul, 1959.

Gauch, Peter/Schluep, Walter R./Schmid, Jörg/Emmenegger, Susan: Schweizerisches Obligationenrecht Allgemeiner Teil, Band I, Zürich, 2008.

Gümüş, M. Alper: “6098 Sayılı Türk Borçlar Kanunu'nun Akdi Önalım Hakkına İlişkin Hükümlerinin (TBK m. 237/III. 238, 239 ve 240-242) Değerlendirilmesi", Yeditepe Üniversitesi Hukuk Fakültesi Dergisi, Prof. Dr. Erhan ADAL'a Armağan, Özel Sayı, C. VIII/2-IX/1, Y. 20112012, S. 1-2, s. 435-453.

Günay, Erhan: Önalım Hakkı, 2. Baskı, Seçkin Yayınevi, Ankara, 2018.

Gürsoy, Kemal Tahir/Eren, Fikret/Cansel, Erol: Türk Eşya Hukuku, 2. Bask1, Ankara Üniversitesi Hukuk Fakültesi Yayınları, Ankara, 1978.

Karahasan, Mustafa Reşit: Türk Medeni Kanunu Eşya Hukuku, İki Cilt, Ankara, 1977.

Karahasan, Mustafa Reşit: Yeni Türk Medeni Kanunu Eşya Hukuku, 1. Cilt, Arıkan Basım Yayım, İstanbul, 2007.

Keller, Max/Schöbi, Christian: Das Schweizerische Schuldrecht, Band I, Allgemeine Lehren des Vertragsrechts, Basel, 1988.

Kırca, Çiğdem: “Önalım Hakkı Konusunda Medeni Kanundaki Değişiklikler”, Prof. Dr. Ömer TEOMAN'a 55. Yaş Günü Armağanı, İstanbul, 2002, s. 1179-1203.

Kırkbeşoğlu, Nagehan: Önalım Hakkı, 1. Baskı, On İki Levha Yayınları, İstanbul, 2020. 
Kırkbeşoğlu, Nagehan: Türk Özel Hukukunda Kısmi Hükümsüzlük, Vedat Kitapçı1ı, İstanbul 2011.

Kizir, Mahmut: 6098 Sayılı Türk Borçlar Kanununa Göre Satış İlişkisi Doğuran Haklar ve Özellikle Önalım Hakkına İlişkin Hükümlerin Değerlendirilmesi, Marmara Üniversitesi Hukuk Fakültesi Hukuk Araştırmaları Dergisi, C. 22, S. 3, 2016, Prof. Dr. Cevdet YAVUZ'a Armağan, s. 1770-1792.

Kocayusufpaşaoğlu, Necip/Hatemi, Hüseyin/Serozan, Rona/Arpacı, Abdülkadir: Borçlar Hukuku Genel Bölüm, Birinci Cilt, 6. Bası, Filiz Kitabevi, İstanbul, 2014.

Köylüoğlu, Egemen: Önalım Davası, Ankara, 2011 (Yayımlanmamış Doktora Tezi).

Kramer, Ernst A./Schmidlin, Bruno: Schweizerisches Zivilgesetzbuch Das Obligationenrecht, Band VI, 1. Abteilung Allgemeine Bestimmungen, Allgemeine Einleitung in das schweizerische Obligationenrecht und Kommentar zur Art. 1-18 OR, Bern 1986 (Kramer, Ber.Kom.).

Meier-Hayoz, Arthur: Berner Kommentar, Kommentar zum Schweizerischen Privatrecht, Das Sachenrecht, Das Eigentum, Grundeigentum II, Art. 680-701, Bern, 1975.

Oğuzman, Kemal/Barlas, Nami: Medeni Hukuk, 24. Baskı, Vedat Kitapçılık, İstanbul, 2018.

Ŏguzman, Kemal/Öz, Turgut: Borçlar Hukuku Genel Hükümler, C. 1, 16. Bası, Vedat Kitapçılık, İstanbul, 2018.

Oğuzman, M. Kemal/Seliçi, Özer/Oktay-Özdemir, Saibe: Eşya Hukuku, 22. Bas1, Filiz Kitabevi, İstanbul, 2020.

Oğuzman, M. Kemal: "Dürüstlük Kuralına (MK m. 2) Başvurma Hususunda Bazı Yargıtay Kararlarının Eleştirilmesi”, Prof. Dr. Yaşar KARAYALÇIN'A 65. Yaş Armağanı, Ankara, 1988, s. 407-415.

Okur, Sinan: "Önalım Olgusuna Dair Yeni Bir Kategori; Ekonomik Bakımdan Satışa Eşdeğer İşlem Kavramı Üzerine Mukayeseli Bir İnceleme (TBK m. 240/Art. 216c OR)”, SDÜHFD C. 9, S. 1, Y. 2019, s. 101-258.

Özbilen, Arif Barış: Sözleşmelerin Şekli ve Şekil Yönünden Hükümsüzlüğü, 1. Baskı, On İki Levha Yayınları, İstanbul, 2016.

Özçelik, Barış: "Fiili Taksim Halinde Yasal Önalım Hakkının Kullanılamayacağı Yönündeki Yargitay Uygulamasının Değerlendirilmesi”, TBB Dergisi, Mart-Nisan 2019, Say1 141, s. 253-264. 
Özdek, Yasemin: “Önalımda (Şuf'ada) Vazgeçme ve Bir Yargıtay Kararı”, Dicle Üniversitesi Hukuk Fakültesi Dergisi, Y. 1985, C. 3, S. 3, s. 337369.

Özenli, Soysal: Uygulamada Önalım (Şuf'a) Davaları, 2. Basım, Kazancı Yayınları, Ankara, 1990.

Özkaya, Eraslan: Açıklamalı - İçtihatlı İnançlı İşlem ve Muvazaa Davaları, 7. Baskı, Seçkin Yayınevi, Ankara, 2017.

Rey, Heinz/Strebel, Lorenz: Honsell, Heinrich/Vogt, Nedim Peter/Geiser, Thomas: Basler Kommentar (Bas.Kom.) Zivilgesetzbuch II, Art. 457977 ZBG, Art 1 - 61 SchlT ZGB, Basel, 2011.

Rey, Heinz: Die Grundlagen des Sachenrechts und das Eigentum, Band I, Bern, 2000.

Ruhi, Canan/Ruhi, Ahmet Cemal: Önalım Hakkına Dayalı Tapu İptali ve Tescil Davaları, Yenilenmiş 4. Baskı, Seçkin Yayınevi, Ankara. 2020.

Sayımlar, Zeynep: "Yasal Önalım Hakkının Kullanılmasını Etkileyen Bir Durum Olarak Fiili Taksim", İnönü Üniversitesi Hukuk Fakültesi Dergisi, Özel Say1, Y. 2015, C. 1, s. 627-652.

Saymen, Ferit Hakk1/Elbir, Halit Kemal: Türk Eşya Hukuku, Filiz Kitabevi, İstanbul, 1963.

Sebük, Tahir M.: Türk Medeni Kanununda Şüf'a, Vefa ve İştira Hakları, Kader Basımevi, İstanbul, 1951.

Serozan, Rona: Medeni Hukuk, Vedat Kitapçılık, İstanbul, 2011.

Sirmen, Lale: "Taşınmaz Satımlarında Bedelin Düşük Gösterilmesinin Hukuki Sonuçları" (Bedel), Prof. Dr. Jale G. AKİPEK'E Armağan, Selçuk Üniversitesi Hukuk Fakültesi, Konya, 1991, s. 305-326.

Sirmen, Lale: Eşya Hukuku, 8. Baskı, Yetkin Yayınevi, Ankara, 2020.

Suata, İlay Zeynep: Kanuni Önalım Hakkı, Yetkin Yayınevi, Ankara, 2020.

Sungurbey, İsmet: Medeni Hukuk Sorunları, Beşinci Cilt, İstanbul Üniversitesi Yayınlarından, İstanbul, 1984.

Şans Uçaryılmaz, Talya: Bono Fides (Dürüstlük Kuralı), Yetkin Yayınevi, Ankara, 2019.

Şenol, Nilay: "Taşınmaz Satış Sözleşmelerinde Bedelde Muvazaa ve Sonuçları", YÜHFD, C. XV, 2020/1, s. 305-337.

Şıpka, Şükran: "Yargıtay Kararları Doğrultusunda Taşınmazdaki Değer Artışlarının Kanuni Önalım (Şuf’a) Bedeline Yansıtılması”, İstanbul 
Üniversitesi Mukayeseli Hukuk Araştırmaları Dergisi, 1996, C. 20, s. 31-39.

Taman Şıpka, Şükran: Türk Hukukunda Kanunî Önalım (Şuf’a) Hakkı (MK.m.659) Hukuki Niteliği ve Kullanma Koşulları, Alfa Basım Yayım, İstanbul, 1994.

Tandoğan, Haluk; Borçlar Hukuku Özel Borç İlişkileri C. I/1, 6. Basım, Vedat Kitapçılık, İstanbul, 2008.

Tekinay, Selahattin Sulhi/Akman, Sermet/Burcuoğlu, Haluk/Altop, Atilla: TEKINAY Eşya Hukuku, C. 1, (TEKİNAY Eşya), 5. Baskı, Filiz Kitabevi, İstanbul, 1989.

Tekinay, Selahattin Sulhi/Akman, Sermet/Burcuoğlu, Haluk/Altop, Atilla: TEKINAY Borçlar Hukuku (TEKINAY Borçlar), 7. Baskı, Filiz Kitabevi, İstanbul, 1993.

Tekinay, Selahattin Sulhi: Taşınmaz Mülkiyetinin Takyitleri II/1, Filiz Kitabevi, İstanbul, 1988.

Tunaboylu, Müslim: Önalım (Şuf'a) Davaları, 5. Baskı, Yetkin Yayınevi, Ankara, 2013.

Tuor, Peter/Schnyder, Bernhard/Schmid, Jörg/Rumo-Jungo, Alexandra: Das Schweizerische Zivilgesetzbuch, 2009.

Uyar, Talih: "Yargıtay Kararlarında "Dürüstlük (Objektif İyiniyet)" Kuralı (MK.2/I) ve "Hakkın Kötüye Kullanılması Yasağı" (MK.2/II)", Prof. Dr. SEYFULLAH EDİS'E ARMAĞAN, İzmir, 2000, s. 439-465.

Von Fischer Lehmann, Marie: ZGB Kommentar, Schweizerisches Zivilgesetzbuch, OFK - Orell Füssli Kommentar, 2016, Art. 681 (https://www.swisslex.ch/).

Wiegand, Wolfgang: Honsell, Heinrich/Vogt, Nedim Peter/Wiegand, Wolfgang: Basler Kommentar (Bas.Kom.) Obligationenrecht (OR) I, Art. 1-529, Basel, 2011.

Yıldız, Ekrem: Önalım Davaları, 2. Baskı, Vedat Kitapçılık, İstanbul, 2008.

Zevkliler, Aydın/Acabey, Beşir/Gökyayla, Emre: Zevkliler Medeni Hukuk, 6. Baskı, Seçkin Yayınevi, Ankara, 1999.

http://www.kazanci.com.tr/

https://www.swisslex.ch 


\section{KISALTMALAR}

\begin{tabular}{|c|c|}
\hline Art. & : Artikel (madde) \\
\hline b. & : Bend \\
\hline Bas.Kom. & : Basler Kommentar \\
\hline Ber.Kom. & : Berner Kommentar \\
\hline BGB & : Bürgerliches Gesetzbuch \\
\hline Bkz. & : Bakınız \\
\hline C. & : Cilt \\
\hline E. & : Esas \\
\hline HD & : Hukuk Dairesi \\
\hline $\mathbf{K}$. & : Karar \\
\hline Karş. & : Karşılaştırınız \\
\hline KHK & : Kanun Hükmünde Kararname \\
\hline m. & : Madde \\
\hline $\mathbf{N}$ & : Numara \\
\hline OR & : Obligationenrecht (İsviçre Borçlar Kanunu) \\
\hline RG & : Resmi Gazete \\
\hline RGZ & $\begin{array}{l}\text { : Entscheidungen des deutschen Reichgerichts in } \\
\text { Zivilsachen (Hukuk Davalarına İlişkin Alman İmparatorluk } \\
\text { Mahkemesinin Kararları) }\end{array}$ \\
\hline s. & : Sayfa \\
\hline S. & : Say1 \\
\hline SDÜHFD & : Süleyman Demirel Üniversitesi Hukuk Fakültesi Dergisi \\
\hline T. & : Tarih \\
\hline TBB & : Türkiye Barolar Birliği \\
\hline TBK & : Türk Borçlar Kanunu \\
\hline TMK & : Türk Medenî Kanunu \\
\hline vd. & : ve devamı \\
\hline Y. & : Y11 \\
\hline YHGK & : Yargitay Hukuk Genel Kurulu \\
\hline YİBK & : Yargıtay İçtihadı Birleştirme Kararı \\
\hline YÜHFD & : Yeditepe Üniversitesi Hukuk Fakültesi Dergisi \\
\hline ZGB & : Schweizerisches Zivilgesetzbuch (İsviçre Medeni Kanunu) \\
\hline
\end{tabular}

